4 nordon 



\section{Söfnun og meðhöndlun spilliefna í litlum slippum á Norðurlöndum}

Knut Forberg, Akvaplan-niva og Anita Evenset, Akvaplan-niva 
Söfnun og meðhöndlun spilliefna í litlum slippum á Norðurlöndum

TemaNord 2010:535

(C) Nordisk Ministerråd, København 2010

ISBN 978-92-893-2052-8

Ritið er hægt að prenta eftir pöntun (PoD) sem send er á www.norden.org/order. Fleiri rit er að finna á www.norden.org/is/utgafa.

Norræna ráðherranefndin

Store Strandstræde 18

DK-1255 København K

Sími (+45) 33960200

Bréfasími (+45) 33960202

\section{Norðurlandaráo}

Store Strandstræde 18

DK-1255 København K

Sími (+45) 33960400

Bréfasími (+45) 33111870

www.norden.org

\section{Norrænt samstarf}

Norræna samstarfið er eitt umfangsmesta svæðasamstarf í heiminum. Samstarfið byggir á landfræðilegri legu, sameiginlegri sögu og menningu og nær til Danmerkur, Finnlands, Íslands, Noregs og Svípjóðar auk sjálfstjórnarsvæðanna Færeyja, Grænlands og Álandseyja.

Norræena samstarfið er pólitískt, efnahagslegt og menningarlegt og skiptir miklu í evrópsku og alpjóðlegu samstarfi. Í norrænu samstarfi er unnið að pví að styrkja stöðu Norðurlandanna í sterkri Evrópu.

Með norræenu samstarfi er unnið að pví að efla norræna og svæðisbundna hagsmuni í alpjóðlegu umhverfi. Sameiginleg gildi landanna styrkja stöðu Norðurlandanna og skipa peim meðal peirra svæða í heiminum par sem nýsköpun og samkeppnishæfni er mest. 


\section{Efnisyfirlit}

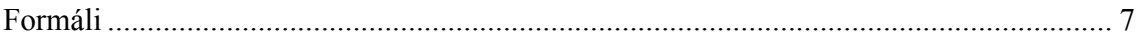

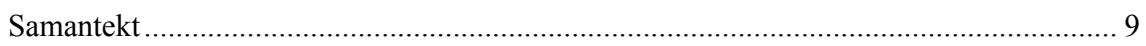

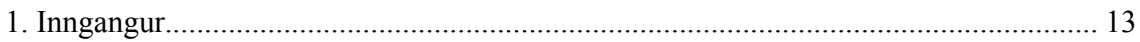

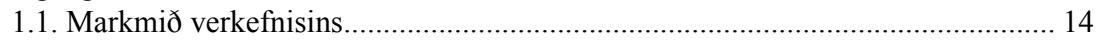

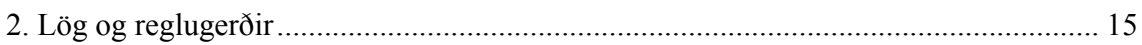

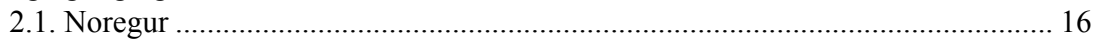

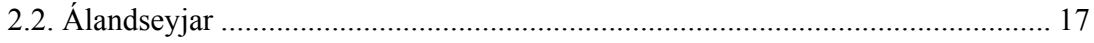

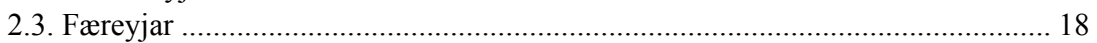

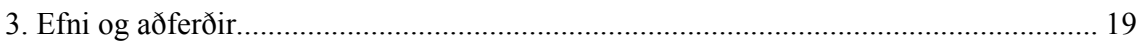

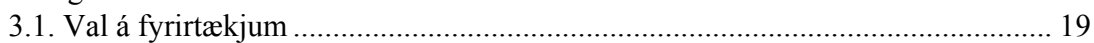

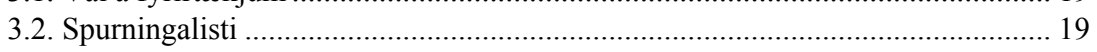

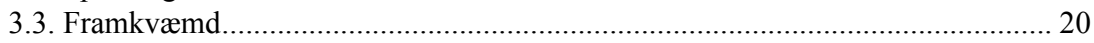

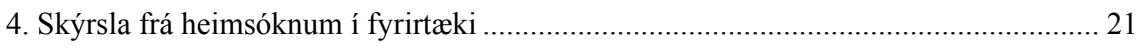

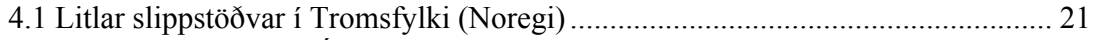

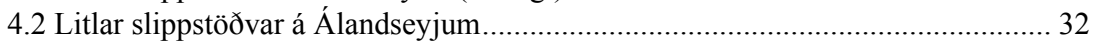

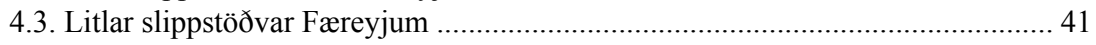

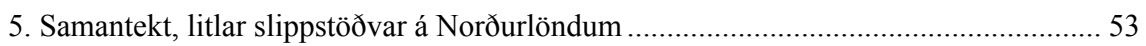

5.1. Samantekt, litlar slippstöðvar á Norðurlöndum ............................................... 53

5.2. Samantekt, litlar slippstöðvar á Álandseyjum .................................................... 53

5.3. Samantekt, litlar slippstöðvar á Færeyjum ........................................................ 54

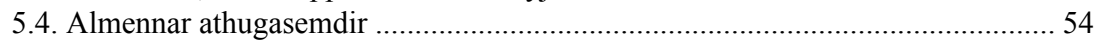

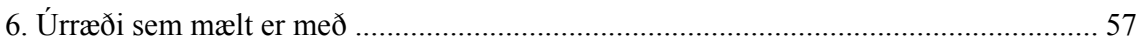

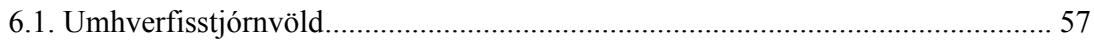

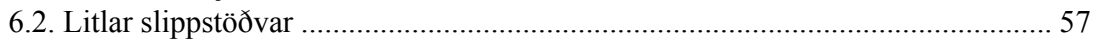

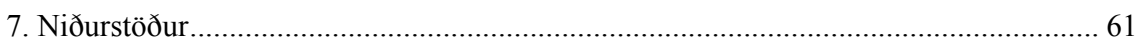

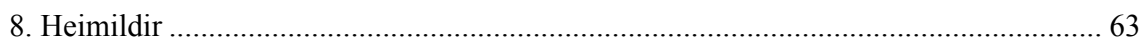

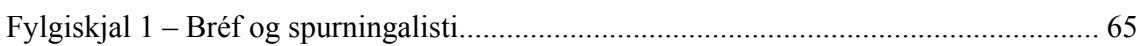





\section{Formáli}

Vitað er að slippstöðvar valda mengun í sjávarumhverfi. Á síðari árum hefur athygli umhverfisstjórnvalda beinst í auknum mæli að starfsemi slippstöðva, en pau hafa pó aðeins haft bolmagn til að sinna stærri skipasmíðastöðvum. Pá he fur eftirlit m eð sl ippstöðvum verið mjög mismunandi eftir löndum. Í öllum löndunum er fj öldi lí tilla s lippstöðva m eðfram sjávarsíðunni sem annast vi ðhald á bát um. Margar peirra eru ein yrkjafyrirtæki e $n$ á öðr um starfa 3-10 manns. Mar gar eru a ukabúskapur m eðfram annarri s tarfsemi. Stöðvarnar sinna aðallega minnstu bátum strandveiðiflotans (25-30 feta) og skemmtibátum.

Umhverfisstjórnvöld hafa lítið fy lgst með pessari starfsemi og pv í er lítið v itað u m u mhverfismeðvitund eigendanna og úrræði p eirra til að vernda u mhverfið. Ráðist var í verkef nið sem pessi skýrsl a fjallar um, að frumkvæði u mhverfisstjórnvalda í Fi nnmörku (Noregi), Færey jum og Álandseyjum til pess að auka $\mathrm{p}$ ekkingu á rekstri, starfsv enjum o $\mathrm{g}$ viðhorfum á litlu m slipp stöðvum. Norræ na ráðherranefndin fjármagnað i verkefnið og Akvaplan-niva AS sá um framkvæmd pess. Pær slippstöðvar sem könnunin náði til voru vald ar í samstarfi við u mhverfisstjórnvöld í Noregi (Evy Jø rgensen, Fylkesmannen i Finnmark), Færey jum (Suni Petersen, Umhvørv isstovan) og Álan dseyjum (Mia Westman, miljöinspektör, Ålan ds m iljö- och hälsoskyddsmyndighet). Akvaplan-n iva vill pakka pessum aðilum fyrir gott samstarf um verkefnið. 



\section{Samantekt}

Vitað er að slippstöðvar valda mengun sjávar. Á síðari áru m hafa umhverfisstjórnvöld á Norðurlöndum í mismiklum mæli fylgst með stærri slippstöðvum og beint fyrirmælum til peirra. Lítið eftirlit hefur verið með litlum slippstöðvum, par sem starfa y firleitt $1-5 \mathrm{~m}$ anns, og pví e $\mathrm{r}$ lítið vitað um rekstrarhætti og um hverfisvitund peirra. Verkefnið sem hér er fjallað u m v arð til að frum kvæði u mhverfisstjórnvalda í Finnm örku (Noregi), Færey jum, Álan dseyjum og Íslandi. Markmiðið var að safna upplýsingum um rekstrarhætti, pekki ngu á notkun hættulegra efna við viðhald á bá tum á litlu m slippstöðvum á eftirfarandi prem ur stöðum : Tromsfylki í Noregi, Færey jum og Álandsey jum. Markhópuri nn var slippstöðvar með færri en 4-5 sta rfsmenn sem annast viðgerðir o g viðhald á bátum. Við gerð yfirlitsins var aðallega stuðst við heim sóknir á vinnustaði sem valdir voru í sam ráði milli Akvaplan-niva og umhverfisstjórnvalda á hverjum stað.

Fyrir valinu urðu fjögur fyrirtæki í Tromsfylki, brjú á Álandseyjum og prjú í Færeyjum (færeysku slippstöðvarnar eru ívið stærri en í Tromsfylki og á Álandseyjum).

Umhverfisaðstæður slippstöðvanna eru m jög mismunandi á peim premur svæðum sem urðu fyrir valinu. Álandseyjar liggja í Eystrasalti par sem hafsvæði eru undir m iklu álagi vegna næringarsalta og mengunar. Í Tromsfylki í Noregi og í Færey jum hins vegar er endurnýjun vatns góð og mengun minni. Álendingar og Norðmenn purfa að hlýða almennu m EB-tilskipunum og -reglugerðum, en Færeyingar eru hvorki aðilar að ESB né EES. Á öllum premur stöðum gilda landslög og regl ugerðir um fyrirtæki sem losa mengandi efnasam bönd. Hvergi á peim stöðum sem heimsóttir voru hafa verið settar stranga ri reglur, innanlands eða svæðisbundið, um notkun og afhendingu hættulegra efna, ólíkt pví sem tíðkast í Danmörku og Svípjóð.

Könnuð voru nokkur fyrirtæki sem annast viðgerðir og viðhald bát a á peim premur svæðum sem urðu fy rir valinu. Ætla má að tekist hafi að fanga í meginatriðum mynd af pekki ngu og vi ðhorfum til u mhverfisvænna starfshátta sem ríkja hjá fyrirtækjum af pessu tagi.

\section{Rekstur}

Í heimsóknum okkar á litlu slippina urðum við vör við góða starfshætti og annað sem betur $\mathrm{m}$ ætti fara. Ekkert fyrirtækjanna hafði útbúnað til að fanga eða hreinsa frárennsli og úrgang eftir pvott og skröpun báta á purru landi. Pó hafði eitt peirra sett upp safnge ymi fy rir fastan úrgang sem fellur til eftir háprýstipvott. Hvergi var aðstaða til botnhreinsunar í sjó. 
Meðhöndlun úrgangs var mjög mismunandi. Á einum stað var framúrskarandi aðstaða til að flokka og skila úrgangi, en á öðrum var engin slík aðstaða fy rir hendi. Anna rs staðar pjónaði aðstaðan tilgangi sí num að einhverju leyti. Enginn skýr m unur á starfsháttum og venjum virtist vera á milli svæða.

\section{Dekking}

Starfsmenn pekktu yfirleitt lítið til la ga og reglugerða um slippstöðvar sem losa mengandi efni á landi og í sjó. Engum peirra eigenda eða starfsmanna, sem við ræddum við, var kunnugt um hvaða efni, sem notuð voru á staðnum, gátu valdið skaðlegum áhrifum eða vissu hvaða áhrif losun frá viðhaldi skip a getur haft á lífríki hafsins. Við komumst að raun $\mathrm{u} \mathrm{m}$ að reglugerðir eru óaðgengilegar flestum. Mörg fyrirtæki purfa að kynna sér margar og mismunandi alpjóðlegar tils kipanir og innlendar reglugerðir. Bæta mætti aðgengið til muna ef unnin væri sam antekt á reglugerðum fyrir hinar ýmsu atvinnugreinar (t.d. varðandi losun í andrúmsloft og sjó, meðhöndlun úrgangs o.s.frv.).

\section{Viðhorf}

Flestir viðmælendur okkar sögðust fylgjandi eins umhverfisvænum starfsháttum og kostur er svo fram arlega sem kostnaður er viðráðanlegur. Peir vissu hins ve gar lítið um hvernig koma mætti pví til leiðar. Okkur virtist margir vænta pess að upplýsingar „b ærust peim sjálfkrafa“, p.e. að umhverfisstjórnvöld bæru áby rgðina. Fáir höfðu b orið sig sjálfir eftir nýrri pekkin gu. Prátt fy rir að pekki ng á u mhverfisvænum rekstri hafi almennt verið af skornum skammti voru pó dæ mi pess að v iðhorf og pekking eige nda til um hverfisvænna st arfshátta $\mathrm{v}$ æru tiltölule ga góð. Viðtölin leiddu pó í ljós að pekking og umhverfisvitund eru ekki endilega trygging fyrir pví að umhverfisvænir starfshættir séu viðhafoir.

\section{Aðgerðir}

Bæði umhverfisstjórnvöld og eigendur slippstöðva geta gripið til ýmissa úrræða til að bæta starfshætti á litlu m slippstöðvum. Umhverfisstjórnvöld geta útbúi ð og dreift uppl ýsingum um lög, regl ur og úrræði til að bæta starfshætti. Pá væri ráðlegt að $\mathrm{s}$ tjórnvöld hefðu sam band við e igendur lítilla slippa með gagnkvæm upplýsingask ipti í huga. Líta parf betur á pjónustuhafnir par sem ekki er hefo bundinn slipp ur (sleði á teinum ) heldur færanl egur lyftibúnaður til að lyfta bátum og „leggja“ peim hvar sem er á lóðinni. Pörf vir ðist vera á eftirliti og jafnvel vottunarkerfi til pess að bæta umhverfisvitund á slippstöðvum.

Eigendur slippa sem annast viðhald á bátum purfa sjálfir að kynna sér ný lög, reglugerðir og pa u úrræði sem eru fy rir hendi til pess að gera 
starfsvenjur og aðstöðu á staðnum umhverfisvænni. Staðbundin u mhverfisstjórnvöld purfa að aðstoða við pekkingaröflun og eiga virk samskipti við fyrirtækin.

Litlar slippstöðvar geta kom ið upp aðstöðu f yrir fl okkun og meðhöndlun spilliefna. Alls staðar sem við komum voru aðstæður fyrir hendi til að safna slíkum úrgangi.

Skapa parf einfalda aðstöðu á öllu m litlum slippstöðvum til að safna föstu efni úr frárennsli. Á slippstöðvum par sem margir bátar eru hreinsaðir árlega parf einnig aðstöðu til að hreinsa frárennsli. 



\section{Inngangur}

Á síð ari áru m hefur verið sýnt fram á að $\mathrm{s}$ lippstöðvar meðfram $\mathrm{s}$ jávarsíðunni valda töluverðri mengun á sjávarbotni. Helstu mengunarvaldar hafa reynst $\mathrm{v}$ era fjöl arómatísk $\mathrm{v}$ etniskolefni $(\mathrm{P} A H)$, tríbútý ltin $(\mathrm{T} \quad \mathrm{BT})$, fjölkljóruð bífenýlsambönd (PCB) og nokkrir pung-málmar (aðallega kop$\operatorname{ar}(\mathrm{Cu})$, sínk $(\mathrm{Zn})$ og blý $(\mathrm{Pb}))$. Mest er vitað u $\mathrm{m}$ lo sun frá stærri skipasmíðastöðvum en pað gefur auga leið að litlar slippstöðvar eiga einnig pátt í að menga hafið.

Alls staðar meðfram ströndum Norðurlanda eru starfræktar litlar slippstöðvar, oft í tengslum við smábátahaf nir og/eða vélaverkstæði. Pessi fyrirtæki pjónusta minnstu báta stra ndveiðiflotans og skemm tibáta. Við viðhald á bátum undir vatnslínu parf að setja pá í slipp. Dæmigert viðhald á litlum slippstöðvum felst í að fjarlæ gja gróður (hrúðurkarla, kræklinga, pörunga) og sm yrja botninn með gróð urhindrandi efnum. Su m fy rirtæki annast einnig einfalt viðhald og viðgerðir á vélum. Á flestu m litlum slippstöðvum er notast við sleða á t einum til að draga bátana á land. Á dæmigerðri slippstöð eru nokkrir sleðar á teinum til að draga báta á land. Pað takmarkar að sjálfsögðu fjölda bá ta á hvern tíma, og par m eð einnig mengun um hverfisins. Par sem teinarn ir eru yfirleitt 1 sjálfri fjörunni lendir allt sem skrapað er eða spúlað af bátskrokknum beint í sjávarmálinu og berst paðan út á sjó (í flóði eða við spúlun). Litlar slippstöðvar eru y firleitt í dreifbýli. Nær péttbýli eru sm ábátahafnir par sem oft eru dráttarbrautir og gert að bátum, en slík aðstaða flokkast almennt ekki sem slippir eða skipasmíðastöðvar.

Í bátahöfnum eru oft stór stæði sem auðvelt er að stækka, og par er hægt að ly fta og flytja til mikinn fjöld a báta með ly ftum og krönu m. Stórir kranar og lyftur gera pað kleift að afgreiða marga báta á hvern tíma, oft er um að ræða jafn stó ra báta og á venjulegu $\mathrm{m}$ litlum slipp stöðvum. Í skemmtibátahöfnum er y firleitt boðið upp á stæði og gey mslu fyrir báta, auk vélapjón ustu og sölu á hlutum til viðhalds. Eig endurnir sjá að mestu leyti sjálfir u m slípun báta sinna og viðhald á vélu m. Slíkt fy rirkomulag reynir mikið á u mhverfisvæn vinnub rögð við viðh ald á bátu $\mathrm{m}$. Lögum samkvæmt ber bátseigandi ábyrgð á úrgangi og eigin losun mengandi efna. En par sem vinnan fer fram á lóð fy rirtækisins ber fyrirtækið í raun ábyrgð á mengun sem verður eftir á staðnum.

Strangari kröfur um sö fnun úr gangs gætu kallað á viðamiklar breytingar og endurbætur hjá mörgum slippstöðvum. Í m örgum tilvikum krefst pað tö luverðra fjárfestinga. Einhverjar stærri skipasm íðastöðvar geta ráðið vi ð pann kostnað en tekjur minni slippst öðva duga ekki til. Litlar slippstöðvar purfa pví að le ita raunhæfra tæknilausna til pess að skapa hentug a og full nægjandi aðstöðu fyrir söfnu n úrgangs. Re ynslan 
hefur sýnt að margir slippstöðvaeige ndur og starfsmenn peirra eru ekki meðvitaðir um að peir meðhöndli mengandi efni og eigi pátt í mengun sjávar.

\subsection{Markmið verkefnisins}

Markmið verkefnisins sem hér er grei nt frá var a $ð$ afla upp lýsinga um rekstrarhætti, pekkingu og viðhorf til notkunar á hæ ttulegum efnum við viðhald á bátum á litlum slippstöðvum á premur stöðum á Norðurlöndum: Tromsfylki í Noregi, Færeyjum og Álandseyjum.

Eigendur slippstöðva bera sjálfir áby rgð á að k ynna sér lög og reglugerðir sem gilda um starfsemi peirra en ekki er gefið að peir geri pað. pví fólst verkefnið einnig í bví að kanna pekkingu pessara aðila á gi ldandi lögum og reglugerðum.

Mikilvægt er að u mhverfisstjórnvöldum sé kunnugt um rekstrarhætti, pekking og viðhorf y firmanna og starfsmanna á litlum slippstöðvum pegar unnið er að um hverfisbótum meðfram sjávarsíðunni. Annað markmið verkefnisins var að veita ei gendum slippstöðvanna upplýsi ngar sem auðvelduðu peim að bæta starfshætti og grípa til einfaldra úrræða til að draga úr losun og bæta meðhöndl un sp illiefna. Markhópur verke fnisins var slippstöð var með færri en 4-5 star fsmenn sem annast viðgerðir og viðhald á bátum . Viðfangsefni pess vor u litlar slippstöðvar en auk pess var ákveðið að taka með í könnunina eina skemmtibátahöfn m eð slippi sem dæmi um annars konar rekstur sem veldur einnig mengun.

Við gerð y firlitsins var aðallega stuðst við heimsóknir á pá vinnustaði sem höfðu orðið fyrir valinu. 


\section{Lög og reglugerðir}

Alls staðar á Norðurlöndum eru innlend lög og reglugerðir sem öll atvinnufyrirtæki verða að virða. Auk pe ss gilda almennar EB-gerðir, sem einnig eru teknar upp í EFTA/EES-ríkjum á Norðurlöndum. Gerðirnar eru innleidd ar í löggjöf landanna , m .a. með reglugerðum . Í reglugerðunum er greint frá markmiðum sem ESB hefur sett en síðan er pað í höndum hvers ríkis hvern ig pað nær pví m arkmiði. Norðm enn og Íslendingar eru aðilar að EES-sam ningnum og eru pví skuldbun dnir peim gerðum, p.e. tilskipunum og reglugerðum, sem honum fy lgja. Álendingar eru skuldbun dnir EB-gerðum en Færey ingar standa utan við Ev rópska efnahagssvæðið. EB-ger ðir ráða almennu $m$ markmiðum u mhverfisstjórnunar en hverju ríki e r í m örgum tilvikum frjálst að setja strangari reglur en par er kveðiðá um . Hvorki Norðmenn, Álendingar n é Færeyingar hafa sett strangari reglur varðandi mengunarvarnir en kveðið er á um í EB-gerðum.

Ýmsar tilskipanir og reglugerðir va rða starfsemi lítilla slippstöðva. Tilskipun 76/464/EBE um mengun af völdum tiltekinna hættulegr a efna sem losuð er í vatn á við öll ríki sem EES-sam ningurinn nær til. Tilskipunin fjall ar um ,mengun af völdum tiltekinna hoettulegra efna sem losuð eru í vatn “. Samkvæmt tilskipuninni má ekki taka ný efni í notku n við pvotta/- og viðhald á bátum án pess að pau hafi verið sampykkt.

Á Íslandi er tilskipunin innleidd með reglugerð nr. 796/1999 um varnir gegn mengun vatns. Í tilskipuni nni eru tveir listar er varða losunarmörk og gæðam arkmið vegna losunar efna. Á lista I er yfirlit yfir efni sem eru fyrst og fremst valin út frá pví hvað pau eru eitruð, právirk og hvernig pau safnast fy rir í lífveru m (ekki efni sem eru líffræðilega óskaðleg eða breytast hratt í lífrænt óskaðleg efni). Á lista II eru efni sem hafa skaðleg áhrif í vatn aumhverfi en áhrifin eins korðast við ákveðið svæði og fara eftir eiginleikum og legu viðtakans. Á lista I er m.a. að finna lífræn tinsambönd en pau voru algeng í gróðurhindrandi botnmálningu á bátum par til algjört bann gekk í gildi 1. janúar 2008. Á lista II er að finna ko parsambönd, blý, ti n og sæfiefni, efni sem enn má nota í botnmálningu sa mkvæmt EB-gerðinni. Í hvert sinn se $\mathrm{m}$ pessi e fni eru losuð parf að liggja fy rir leyfi par sem losunarkröfur koma skýrlega fram (396L0061: TILSKIPUN RÁĐSINS 96/61/EB frá 24. septem ber 1996 um sampættar mengunarvarnir og eftirlit með mengun: htt p://brunnur. stjr.is/ees.nsf/385499142c7e4810002567590058573a/97d945f642d324c5 $00256700004 \mathrm{e} 18 \mathrm{a} 3$ ?OpenDocument\&Highlight $=0,96 \% 2 \mathrm{~F} 6$ ).

Tilskipun 96/61 EB, um sampættar mengunarvarnir og eftirlit með mengun (IPPC) kveður á um að ábyrgðarmaður fyrirtækis sé skyldugur til að nota bestu fáanlegu tæk ni (BAT) við mengunarvarnir í peim atvinnu- 
greinum par sem slíkt hefur verið skilg reint og að pær aðferðir ti 1 að ná peim losunarmörkum sem getið er í st arfsleyfi miðist við bestu fáanlegu tækni. Pað fe llur pví í hlut um hverfisstjórnvalda að sjá til pess að le yfi séu aðeins veitt ef stuðst er við bestu fáanlegu tækni.

Reglugerð (EB) nr. 1907/ 2006 um skrá ningu, mat, leyfisveitingu og takmarkanir, að pví er varðar efni (R EACH) er hl uti af nýlegri efnalöggjöf ESB og á að efla stjórnun á efnum og efnablönd um í Evrópu . REACH kemur að miklu leyti í stað efnalöggjafar landanna og mun hafa víðtæk áhrif í atvinnulífinu, allt frá st ærri efnaiðnaði til minni fyrirtækja sem framleiða, flytja inn, nota eða dreifa efnum, hvort sem um er að ræða hrein efni, efni í efnablö ndum eða í hlutum, og sem fram leiða eða flytja inn efni til markaðssetningar á Evrópska efnahagssvæðinu. Á Íslandi er REACH-reglugerðin innleidd með reglugerð nr. 850/2008.

Rammatilskipun um vatn (tilskipun 2000/60/EB um aðgerðaramma Bandalagsins um stefnu í vatnsmál um) er önnur tilskipun sem hefur pýðingu $\mathrm{f}$ yrir starfsemi fyrirtækja sem losa mengandi efni. Meginmarkmið vatnatilskipunari nnar er að ve rnda vatn, hindra frekari rýrnun vatnsgæða og bæta ástand vistkerfa til að tr yggja að vötn njóti heildstæðrar verndar. Jafnfra mt er markmiðið að stuðla að sjálfbærri nýtingu sem by ggir á langtímavernd vatnsauðlindarinnar á grundvelli sjál fbærrar próunar. Til að ná fram markmiðum tilskipunarinnar skal vinna vatnaáætlun, vökt unaráætlun og aðgerðaáætlun. Vatnatilskipunin t ók gildi í aðildarríkjum ESB pann 22. desember 2000 og var felld inn í EESsamninginn 2008. Ástand vatns er mælt út frá vistfræði, vatnsfor mfræði og efnafræði. Við ákvörð un um u mhverfismarkmið skal taka mið af kröfum u $\mathrm{m}$ vatnsvernd o $\mathrm{g}$ um hverfisgæði. Ef ekki er tæknilega framkvæmanlegt eða vegna hlutfallslega of mikils kostnaðar að up pfylla markmiðið um gott vistfræðilegt ástan d með öðrum og um hverfisvænni aðferðum, er sam kvæmt tilskipuni nni svigrúm fy rir aukafrest til að n á settum markmiðum eða draga úr settum kröfum. Tilskipunin gerir einnig kröfur um að gripið sé til aðgerða gegn mengun á v atni samkvæmt lista yfir helstu efnasambönd sem eru sérlega skaðleg lífríki í vatni. Í kjölfar tilskipunarinnar verða gerð ný flokkunar kerfi fy rir vistfræðilegt ástand sem eiga að gilda á EES-svæðinu.

\subsection{Noregur}

Í Noregi eru í gildi lög um mengun og úrgang (mengunarlögin) og ná pau til flestra mengunaruppspretta nema í sam göngumálum. M engunarlögin kveða á u m að engum sé heimilt að menga án sérstaks ley fis. Slík ley fi fyrir einstök fy rirtæki og að vissum skilyrðum uppfylltum eru veitt skv. 11. grein lag anna og ým sum regluger ðum u m mengandi starfsemi. 28. grein mengunarlaga kveður á um bann við að skilja eftir úrgang. Í 8. grein mengunarlaga sem gengu í gildi 1. ágúst 1989 er reglur um að mengunar- 
valdur sé skaðabótasky ldur. Í 55. grein er m.a. kve điðá um að sá sem mengun veldur sé skaðabótaskyldur vegna mengunar óháð eigin sekt.

Umhverfisráđuneytið hefur umsjón með mengunarlögum. Umsókn um losunarleyfi fyrir iðnreks tur o. p.h. er send til norsku umhverfisstofnunarinnar (SFT) eða umhverfisskrifstofu pess sýslumannsembættis sem viðkomandi fyrirtæki heyrir undir.

Á vefslóðinni www.regel hjelp.no er vegvísir á reglugerðir sem eiga við um mismunandi starfsem $i$, en par er einnig að finna sam antekt og einfaldar útskýringar á mengunarlögum. Vefurinn hentar $m$ inni f yrirtækjum sem purfa að $\mathrm{k}$ ynna sér lög o g reglur sem eiga við sta rfsemi peirra.

Í norsku iðnaðarreglugerðinni, sem byggir m.a. á IP PC hafa kröfur til slippstöðva, skipasm íðastöðva og yfirborðsmeðhöndlunar m álma verið hertar. Í reglugerðinni eru gerðar staðlaðar kröfur til fyrirtækja eftir stærð peirra. Stærstu fyrirtækin eiga kost á sérleyfum. Hægt er að krefjas t pess að frárennsli og menguðum vökva sé safnað saman. Pegar um er að ræða störf á bry ggju er hægt að krefjast pess að málningarleifum ( eftir skröpun), úrgangsolíu eða öðrum spilliefnum sé safnað saman. Auk pess er krafist sérstakrar varú ðar við hrei nsun (m eð skröpu n, blæs tri eða háprýstipvotti) málningar af bátu $\mathrm{m}$ sem hafa verið málaðir með gróðurhindrandi botnmálningu.

Par sem hætta er á að yfirborðsmeðhöndlun í v atni valdi losun hættulegra efna ber að taka bátana í slipp til blásturshreinsunar, og í slíkum tilvikum er yfirborðsmeðhöndlun í vatni bönnuð. Blásturshreinsun er sjaldgæf á litlum slippstöðvum og pví eiga ákvæ ðin m eira erindi til stærri skipasmíðastöðva.

Meðhöndlun spilliefna er sam kvæmt úrgangslöggjöfinni og reglugerð um endurnýtingu og meðferð úrgangs: FOR 2004-06-01 nr 930: Forskrift om gjenvinning o g behan dling av avf all, sem innleiðir úrgangs löggjöf ESB.

\section{2. Álandseyjar}

Helstu regl ugerðir á Álandsey jum se m snerta slippstöðvar eru Umhverfisverndarlögin (f ramkvæmd tilskipunarinnar u m sampættar mengunarvarnir og eftirlit með mengun) og lög um meðhöndlun úrgangs (Renhållningslagen, ÅFS 1981:3: www.regeringen.ax/socialomiljo/miljo/ lagstiftning_fore_dec2008.pbs).

Samkvæmt lö gum um aðstöðu í höfnu m til að taka á móti úrg angi og farmleifum frá skipum (in nleiðing á tilskipun 2000/59/EB) og lög um u m móttöku úrg angs og farmleifa frá skip um er bátah öfnum sky lt að hafa aðstöðu til að taka á móti úrgangi frá skipu $\mathrm{m}$. Kröfu rnar taka ekki til úrgangs sem til fellur við hreinsun á skipsskrokkum (leifar af botnmálningu). 
Í framkvæmdaáætlun álenskra stjórnvalda í u mhverfismálum 2005-2008 er rétt minnst á eitra ða botnmálningu en m eginvandinn virðist vera sá sem sjávarumhverfi stafar af ofa uðgun næringarefna vegna los unar á frárennsli sem inniheldur fosfat $(\mathrm{P})$ og köfnunarefni $(\mathrm{N})$.

Finnska umhverfisstofnunin (SYKE) se tur reglur um notku n gróð urhindrandi efna í Finnlandi. Hún hefur gert skrá yfir efni sem bannað er að nota, efni sem allir mega nota og efni sem farartækjum er aðeins leyfilegt að nota í atvinnuskyni.

\subsection{Færeyjar}

Í lögum Lög pingsins nr. 134/1 988 um u mhverfisvernd er kveðið á u m meðhöndlun spilliefna við viðhald og viðgerðir á litlum bátum.

Í 15. grein 4. kafla stendur:

„Ekkert sem valdið getur va tnsmengun, má losa í fljót, ár, stöðuvötn, strandsvæði eða færey ska lögsögu eða pað nærri að hæ tta sé á að efn in b erist pang að. Pó kveður 16. grein á um að hægt sé að veit a leyfi til að losa fr árennsli í ár, stöðuvötn, strandsvæði eða færeyska lögsögu.“

\section{Í 15. grein 5. kafla stendur:}

\footnotetext{
„Ekki má hefja undirbúning eða smíðar á starfsemi, mannvirkjum eða búnaði, sem getið er í f ylgiskjölum lagann a, f yrr en st arfsleyfi hefur $f$ engist. Um rædda starfsemi, mannvirki eða búnað má hvorki stækka né breyta, hvorki byggingum né rekstri, pannig að paðh afi áhrif á mengun af völdum $\mathrm{f}$ yrirtækisins, f yrr en stækkun eða breyting hefur verið sampykkt.“
}

Lögin eiga $\mathrm{m}$.a. við u $\mathrm{m}$ fy rirtæki sem annast y firborðsmeðhöndlun á járni, stáli eða öðrum málmum, stálskipasmíðastöðvar og flotkvíar.

Auk pess er til auglýsing á fære ysku um afhendi ngu úr gangs sem snertir litlar slippstöðvar (Kunngerð nr. 147 frá 19. oktober 1995 um burturkast, sum broytt við kunngerð nr. 90 frá 28. september 2007). 


\section{Efni og aðferðir}

\subsection{Val á fyrirtækjum}

Fyrirtækin v oru valin í samráði við um hverfisstjórnvöld í Tr oms og Finnmörku í Noregi, í Færey jum og á Álandsey jum. Fy rir valinu urð u fyrirtæki sem stjórnvöld pekktu til úr eftirliti sínu, en vor u ekki bundin reglubundnu eftirliti eða skoðun. Áður en lagt var í heimsóknir á slippstöðvarnar sendum við sk riflegar uppl ýsingar, rafrænt og bréfleiðis, til a.m.k. fimm fyrirtækja á hverju svæði. Við fengum engin vi ðbrögð og ákváðum pá að hring ja á staðina. Pá fengum við $n$ ánari upplýsingar og ákváðum hvenær farið y rði í fy rirtækin. Aðeins eitt fyrirtæki hafnaði öllu samstarfi við okkur.

Að símtölum loknum var okkur ljóst a ð margir eigendur voru á varðbergi gagn vart pví að upplýsingar um fy rirtæki peirra birtust í o pinberri skýrslu. Til að tryggja samstarfsvilja og hreinskiptni urðum við sammála um að gætt yrði nafnle yndar að einhv erju ley ti, og höfum við yfirleitt sleppt pví að nafngreina einstaklinga og staði í skýrslunni. Pá höfu m við breytt ljósmyndum til pess að dylja auðkenni.

Lista y fir slippstöðvar sem rætt var v ið í verkefninu er að fin na á Töflu 1: Yf irlit yfir f yrirtæki sem heimsótt voru ísam bandi vi $\partial$ könnunina.

Tafla 1. Yfirlit yfir fyrirtæki sem heimsótt voru í sambandi við könnunina.

\begin{tabular}{lrrr}
\hline Staður & Kóði & Fjöldi starfsmanna & Fjöldi báta/ár \\
\hline Tromsfylki, Noregi & $\mathrm{N} 1$ & 1 & 25 \\
Tromsfylki, Noregi & $\mathrm{N} 2$ & $4-5$ & 35 \\
Tromsfylki, Noregi & $\mathrm{N} 3$ & $3-5$ & 220 \\
Tromsfylki, Noregi & $\mathrm{N} 4$ & 1 & $?$ \\
Álandseyjar & $\AA 1$ & 1 & 20 \\
Álandseyjar & $\AA 2$ & 1 & 30 \\
Álandseyjar & $\AA 3$ & 1 & 200 \\
Færeyjar & F1 & 5 & $50-60$ \\
Færeyjar & F2 & 20 & $35-55$ \\
Færeyjar & F3 & 15 & $30-35$ \\
\hline
\end{tabular}

\subsection{Spurningalisti}

Áður en við heimsóttum slippstöðvarnar höfðum við útbúið spur ningalista (Fy lgiskjal 2) og sent hann til f yrirtækjanna. Mikilvægust u spurningarnar fjölluðu um umfang starfseminnar, pekkingu á hættulegum efnum, úrræði til að draga úr losun, pekkingu á reglum, hvernig peim var fylgt og viðhorf til umhverfismála. Flestir eigendur fyrirtækjanna höfðu 
rennt yfir spurningarnar áður en við m ættum á staðinn, en fylltu síðan út eyðublöðin í samstarfi við fulltrúa Akvaplan-niva.

Auk pess að leita svara við spurni ngum skoðuðum við staðhætti og tókum ljósmyndir.

Pegar heim ko $m$ söfnuðum $v$ ið saman svörunum og unnu $m$ ú $r$ upplýsingunum sem par k omu fram. Í næsta k afla v erður greint frá pví helsta sem fram ko m í h eimsóknunum en ály ktanir og athugasemdir eru birtar í aftasta kafla.

\subsection{Framkvæmd}

Slippstöðvarnar sem við heimsóttum fengu eintak af skýrslu verkefnisins. Síðan hringdum við til að athuga hvort menn hefðu spurningar eða athugasemdir varðandi ný úrræði. 


\section{Skýrsla frá heimsóknum í fyrirtæki}

\subsection{Litlar slippstöðvar í Tromsfylki (Noregi)}

Tromsfylki er í No rður-Noregi, norðan No rðurlands og sunn an Finnmerkur. Við strandsvæðin eru öflugi $r$ sjávarfallastrau mar og end urnýjun vatns er y firleitt góð. Í smábáta- og pjónustuhöfnum með slippi er endurnýjun vatns yfirleitt léleg vegna brimbrjóts af náttúrunnar hendi eða manna völdum, sem veitir skjól í höfninni.

Til er skýrsla um mengun í smábátahöfnum í sumum fylkjum Noregs, pó ekki Tromsfy lki (SFT, 2005). Pá hefur verið gert y firlit yfir slippstöðvar meðfram ströndum Noregs (SFT, 2004). Pessi gögn hafa kom ið sér vel við framkvæmd könnunarinnar.

Umhverfisástand er almennt gott $m$ eðfram ströndum Tromsfylkis, en mikil sampjöppun eiturefna hefur greinst á ý msum hafnarsvæðum (t.d. í Harstad og Tromsø) og nokkrum smáb átahöfnum (t.d. Mørck 200 5; Evenset \& Palerud 2004; Evenset et al. 2005).

\subsubsection{Norsk slippstöð, N1.}

Slippurinn er einy rkjafyrirtæki og stendur miðsvæðis í litlu by ggðarlagi. Sunnan við hann er fiskibry ggja en landfy lling í norðri par sem fiskverkunarfyrirtæki starfar (Mynd 1). Detta er dæmigerður slippur eins og peir tíðkast víðast hvar íl itlum po rpum við sjáv arsíðuna. M argir slippi r standa auðir og yfirgefnir, annað hvort vegna brottflutnings eða vegna pess að flytjanlegir kranar eða lyftur hafa leyst pá af hólmi. 


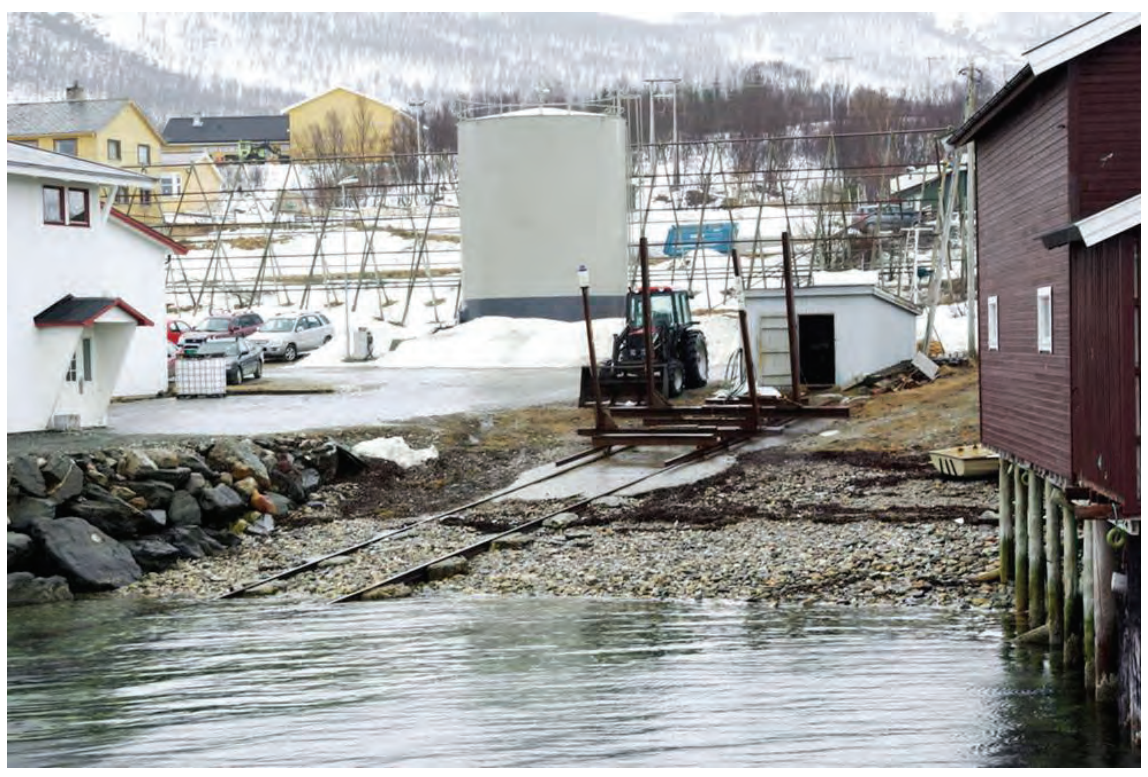

Mynd 1. Slippurinn er í skjóli milli bryggju i suðri og landfyllingar i norðri.

Dráttarbrautin er í halland i fjöru með pangvöx num steinum í neðri hlut a flæðarmálsins. Strandlengjan er að öðru leyti frekar bein með töluverðum sjávarfallastraumum.

Dráttarkerfið er sleði á járn teinum (Mynd 2). Sleðinn er úr h-prófílum og meðfram hliðum hans eru fjórar stoðir en pær er hægt að still a eftir breidd bátsin s sem dreginn er. Sleðinn er ekki á grind og pví hvíla bátarnir á eigin kili í uppsátrinu.

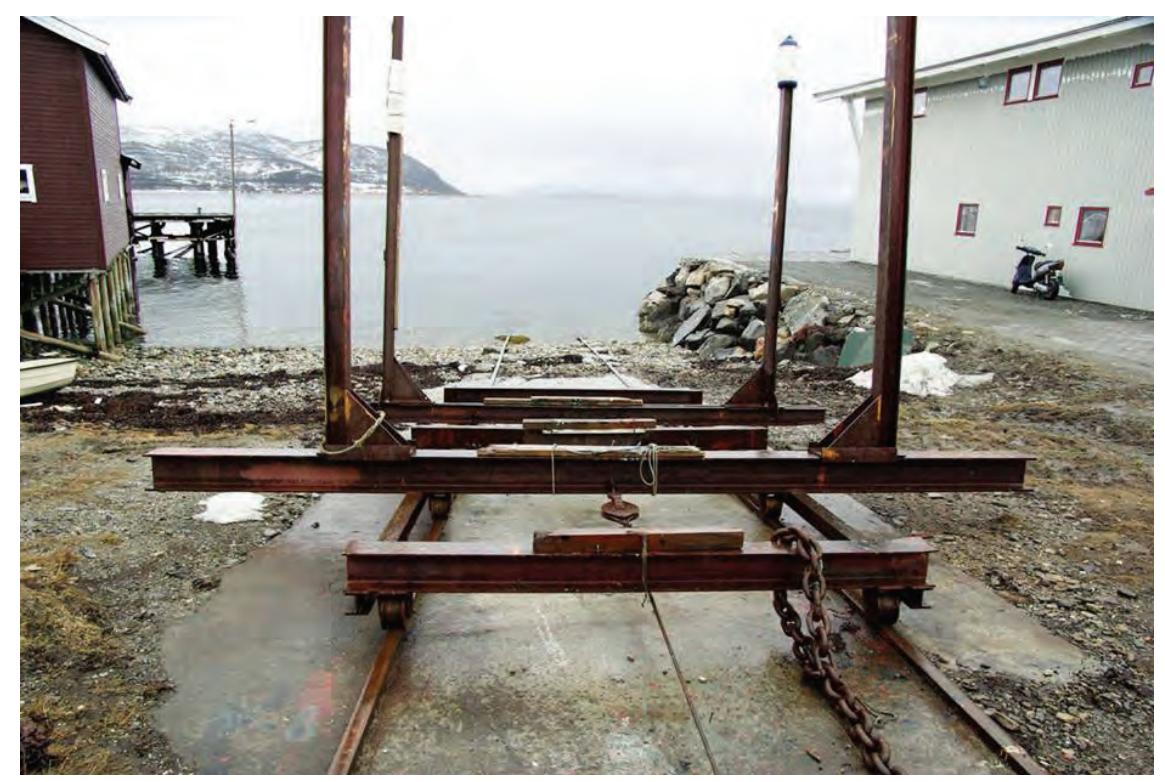

Mynd 2. Dráttarbraut á teinum með fceranlegum stoðum. 
Teinarnir eru festir við jörðu með bry nvörðum stey pubitum sem grafnir eru niður í fjöruna (Mynd 3). Vagninn er dreginn m eð öflugum rafmótor (Mynd 4) sem staðsettur er í litlu sp ilhúsi rétt ofan við flæðarmálið. Á staðnum er aðgangur að rafmagni og vatni.

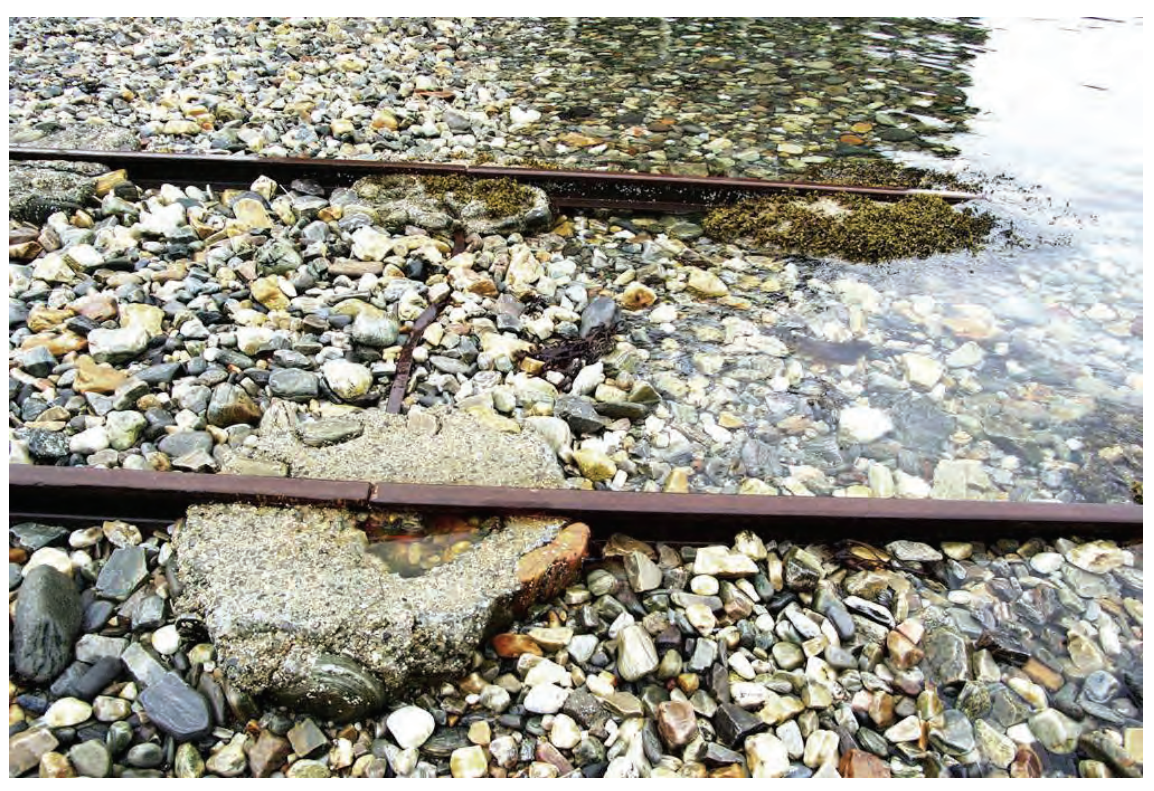

Mynd 3. Dráttarbrautin er brynvarin með sementi. Dangvaxnir steinar i fjörunni.

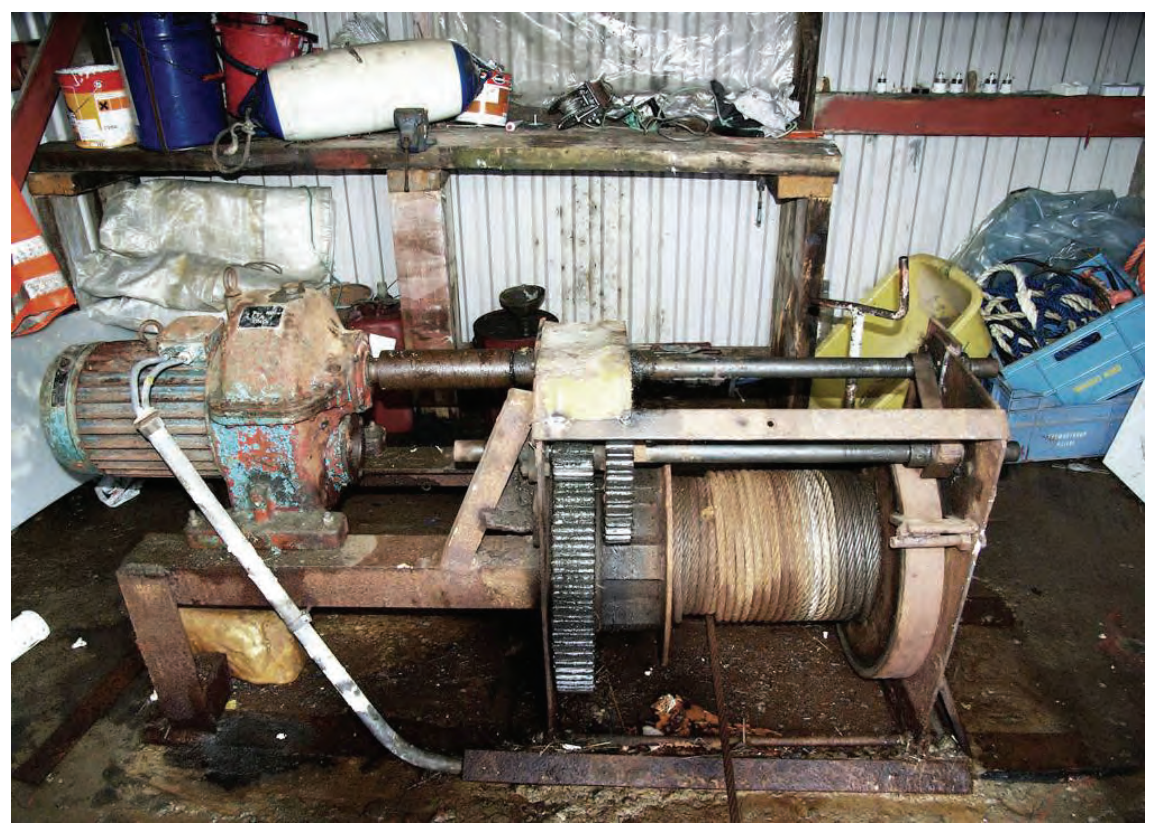

Mynd 4. Spil með $15 \mathrm{~mm}$ vír sem drifið er af rafmótor.

Slippurinn var reistur um 1980 og hefur pjónustað 20-35 feta fiskibáta úr byggðarlaginu. Parna er ekki m ikið um að vera. Áður pjó nustaði slippurinn all $\mathrm{t}$ að 25 báta á ári en nú eru pað u.p $\quad$.b. 10 bátar á ári. 
Slippurinn gæti pjón ustað skemm tibáta en pó eru takmörk fy rir pví hve marga báta væri hægt að taka á land pví par er aðeins eitt uppsátur.

Ekki varð vart við úr gang við s lippinn eða nágrenni hans. Par vor $\mathrm{u}$ heldur ekki gámar til geymslu á spillie fnum. Par hafði áđur staðið tankur fyrir úrgangsolíu, líklega á vegum svei tarfélagsins, en nú var bar enginn. Eigandinn viðurkenndi að pað lægi á að fá nýjan tank.

Fljótt á litið virtist ástand lífríkis við sli ppinn ekki frábrugðið pví sem tíðkast við ó snortna fjöru í nágrennin u. Pari og g amlir hrúðurkarlar (Balanus sp.) voru við neðri hluta dráttarbrautarinnar.

Að sögn eig andans var $\mathrm{ABC}$-botnvör $\mathrm{n}(\operatorname{me} \mathrm{Cu})$ mikið notu ðá staðnum. Eigandinn vissi lítið um hættuleg efni og áhrif peirra á umhverfi sjávar. Hann taldi starfsemi sli ppsins pað litla að mengunarhætta af hennar völdum væri hverfandi. Hann pekkti lítið til reglugerða og hafði engin áform um að koma upp búnaði til að safna saman frárennsli, m álningarleifum o.p.h.

\subsubsection{Norskur slippur, $N 2$.}

Fyrirtækið er staðsett í lit lum vogi uta rlega í op num firði. Fy rirtækið liggur afsíðis, í nágrenninu er hvorki byggð né önnur fyrirtæki (Mynd 5). Fiskeldi er stundað í u.p.b. 2 km. fjarlægð frá slippnum.

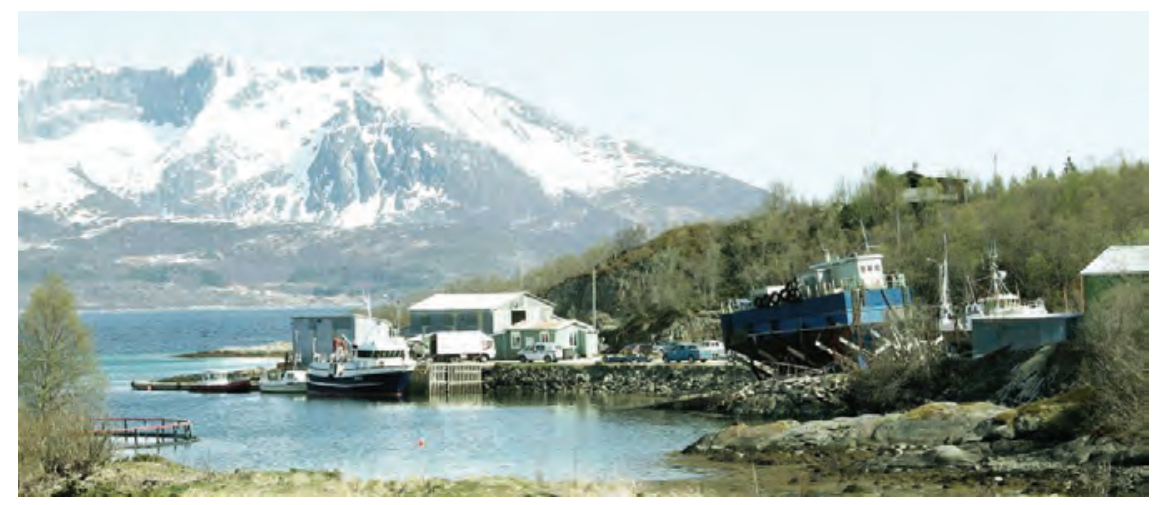

Mynd 5. Slippur N2 er við tiltölulega opið haf i strjálbýli.

4-5 manns starfa í slippnum og annast aðallega viðhald á vélu $m$. Flestir bátar sem teknir eru í slipp eru pvegn ir með vatni (háprýstispúlun) og borin á pá sem vörn botn málning með pensli eða rúllu. Bátaeigendurnir sjá y firleitt sj álfir u m verk ið og botnvörnin er aðallega sjálfgljáan di, af merkinu Jotun Antifoulin g SeaQueen (Mynd 6). Málningin in niheldur m.a. díkoparoxíð og kadmíum. 


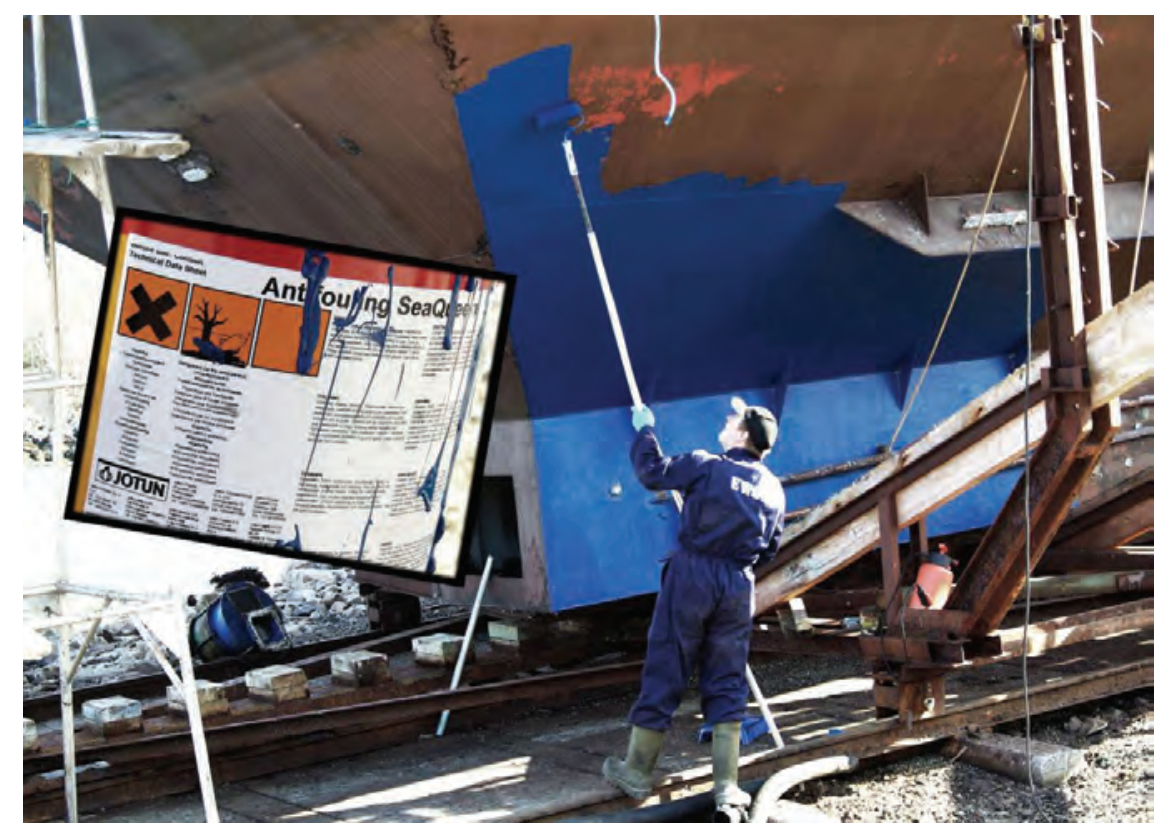

Mynd 6. Á slippstöð N2 sjá eigendur bátanna sjálfir um pvott og botnmálningu.

Fjaran hallar jafnt niður að neðra flæðarm áli og undirlagið er u litlir steinar. Í neðri hluta fjörunnar vex blöðrubang, og dýralífið einkennist af hrúðurkörlum (Balanus sp.) og kræklingum (Mytilus edulis) (Mynd 7).

Við fyrstu sýn virðist gróð ur og dýralíf við dráttarbrautina svipað pví sem gengur og gerist í nærliggjandi fjörum.

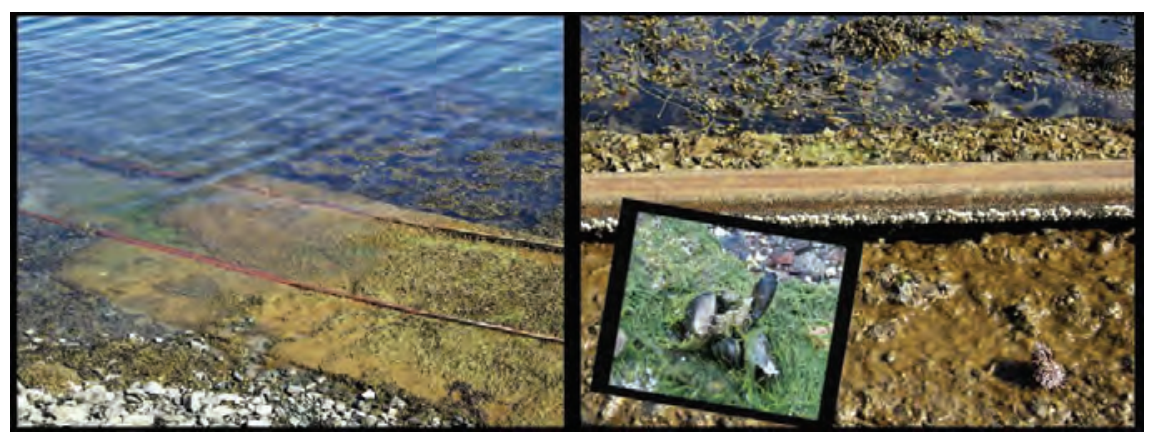

Mynd 7. Við upp sátrið á N2 vaxa fjölcerir hrúðurkarlar á teinunum og krceklingar á milli teinanna.

Í slippnum eru tvær grindu rá teinum sem festir eru á heilstey pt undirlag. Stærri grindin getur t ekið allt að 60 fet a báta. Eigendur slipp sins tóku við rekstrinum árið $2000 \mathrm{og}$ munu hafa hreinsað allan úrgang sem var á svæðinu. Fyrirtækið tekur u.p.b. 10 báta af 25-33 feta stærð og 25 af 33-50 stærð á ári hverju. Peir upp lýsa að ársnotkun á gróðurhindrand i botnmálningu nemi u.p.b. 300 lítru m. Áður by ggðist starfsemin aðallega á viðskiptum við fiskveiðiskip en nú hafa fi skeldisstöðvar leyst skipin af hólmi. Engir skemmtibátaeigendur voru meðal viðskiptavina. 
Parna er enginn búnaður ti 1 að safna málningarleifum eftir spúlun og málun á bátunum og engin áform um að koma upp slíkum búnaði.

Lítil pekking var til staðar u m hvaða virk efni eru bönnuð við botnmálun og menn treystu pví að málning sem key pt er hjá Jotun í Noregi væri ley fileg. Eins var lítil bekking varðandi reglugerðir um losun út í umhverfið og hvers vegna bannað væri að nota ákveðnar tegundir efna.

Parna voru vel merktir gámar til að safna málmum, brennanlegum úrgangi, menguðu vatni (kælivökva mm., ekki frárennsli), mengaðri olíu og nýtanlegri úrgangsolíu (Mynd 8; M ynd 9). Peir fengu greitt fy rir nýtanlega úrgangs olíu en purftu að greiða fyrir að fjarlægja annan úrgang. Einkarekið úrgangsfyrirtæki (Perpetuum Holdin AS) sækir spilli efni hjá fyrirtækinu en sveitarfélagið sér um að fjarlægja annan úrgang.

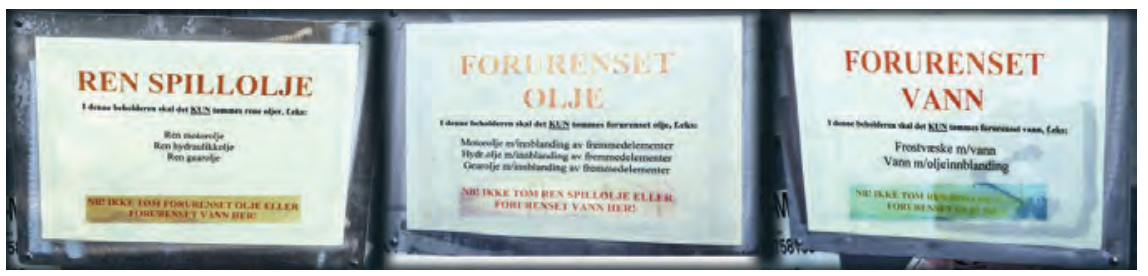

Mynd 8. Merkingar á gámum fyrir fljótandi úrgang á slippstöð N2.

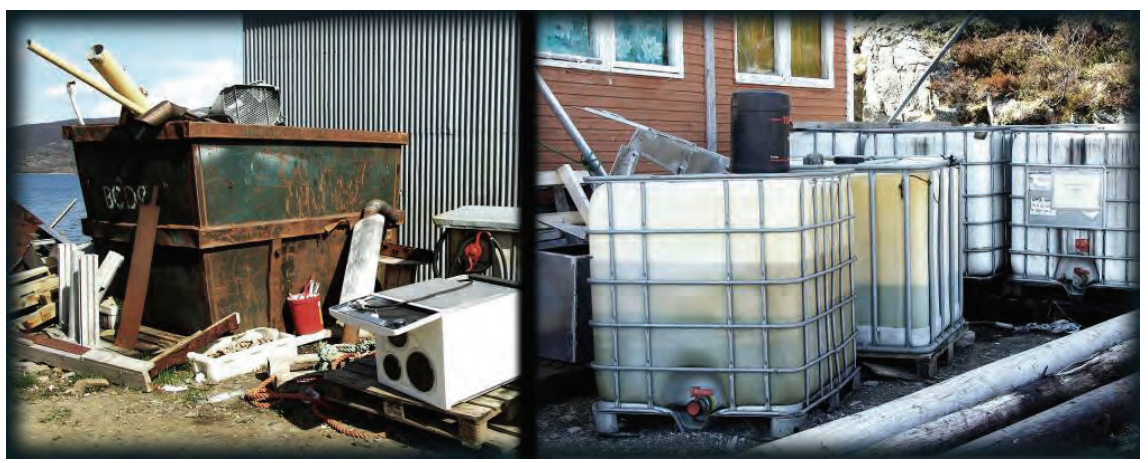

Mynd 9. Gámar fyrir fastan og fljótandi úrgang á slippstöð N2.

Eigendur fyrirtækisins telja sig eiga gó ð sam skipti við um hverfisstjórnvöld sýslunnar. beir segja að arðurinn af rekstrinum renni að mestu í að tryggja að starfshættir uppf ylli umhverfiskröfur. Yfirmaður fy rirtækisins segir pessa forgangsröðun geta verið skýringin á pví að húsakynni fy rirtækisins eru eins gömul og slitin og raun ber vitni.

\subsubsection{Norsk slippstöð, N3.}

Fyrirtækið er staðsett innst í sm ábátahöfn sem liggur í skjóli brimbrjóts. Hafstraumar eru sterkir á pessum slóđum en bri mbrjóturinn hlífir s mábátahöfninni og slippnum. Slippurinn er á iðnaðarsvæði innan u $\mathrm{m}$ ý mis önnur f yrirtæki (Mynd 1 0). Bátamiðstöð rekur slippinn par sem 3-5 
manns annast sölu og bátaviðhald. F yrirtækið skipti r aðallega við eigendur skemmtibáta en einnig sjómenn.

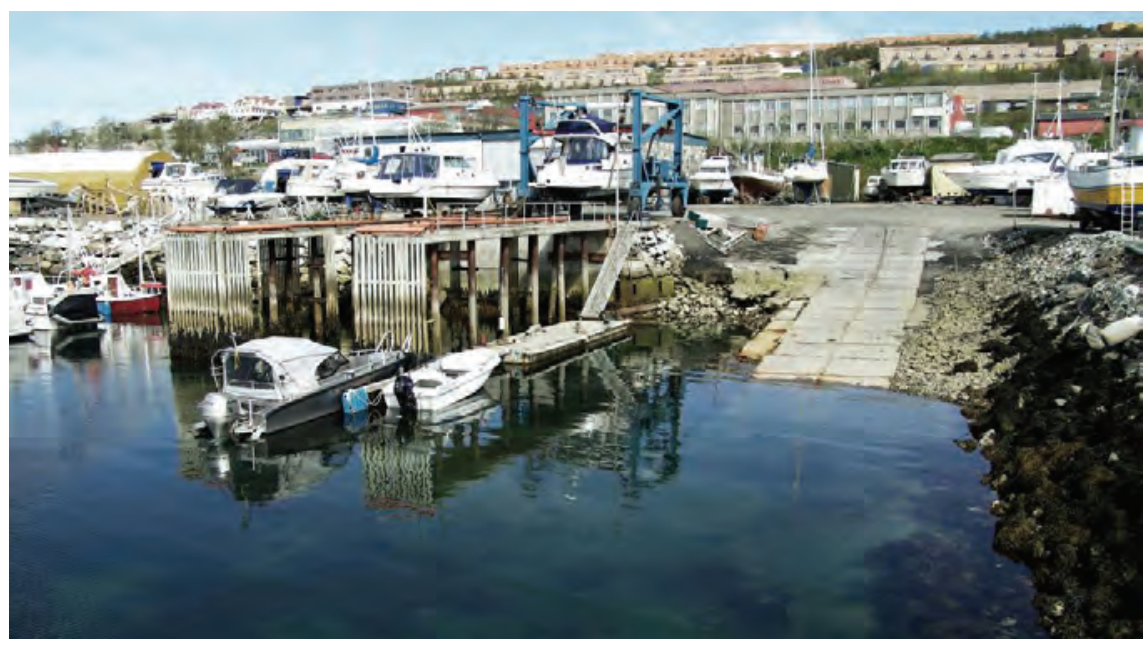

Mynd 10. Á slip pstöð N3 er tvenns konar búna ður til að taka báta á land; grind með lyftitaug og pallur par sem dráttarvél dregur grind á hjólum.

Slippurinn tekur u.p.b. 220 báta á ári og flestir peirra eru á bilinu 20-35 fet. Um 50 b átar eru stærri en 35 fe t (allt að 50 fet). Flestir eru háprýstispúlaðir og málaðir með botnm álningu. Ei nstaka sinnum eru botnar meðhöndlaðir með tveggja pátta epoxým álningu. Vinna með glertrefjar og pess háttar fer að mestu leyti fram innanhúss á veturna.

Bátarnir eru teknir upp með færanlegum krana eða grind á hjólum eftir hallandi steyptum palli. Háprýstispúl unin fer fram á hallandi hellulögðu plani (Mynd 11).

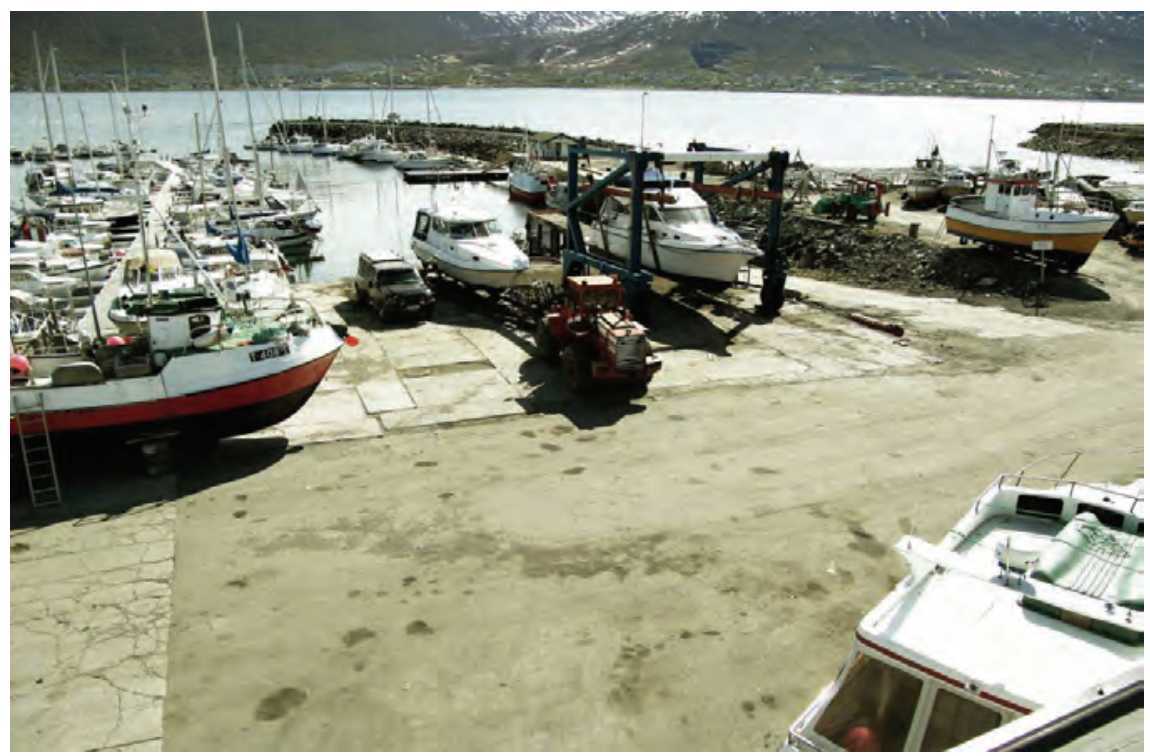

Mynd 11. Uppsátur á slippstöð N3. 
Á slippstöðinni er færanleg grind með lyftibúnaði sem hægt er að leggja á hellurnar. Við neðri kant steypta plansins er búið at leggja botnfal lsfrauð (u.p.b. $1 \times 1 \times 2,5 \mathrm{~m}$ ) par sem frárennsli og málningarleifum er spúlað ofan í (Mynd 12).

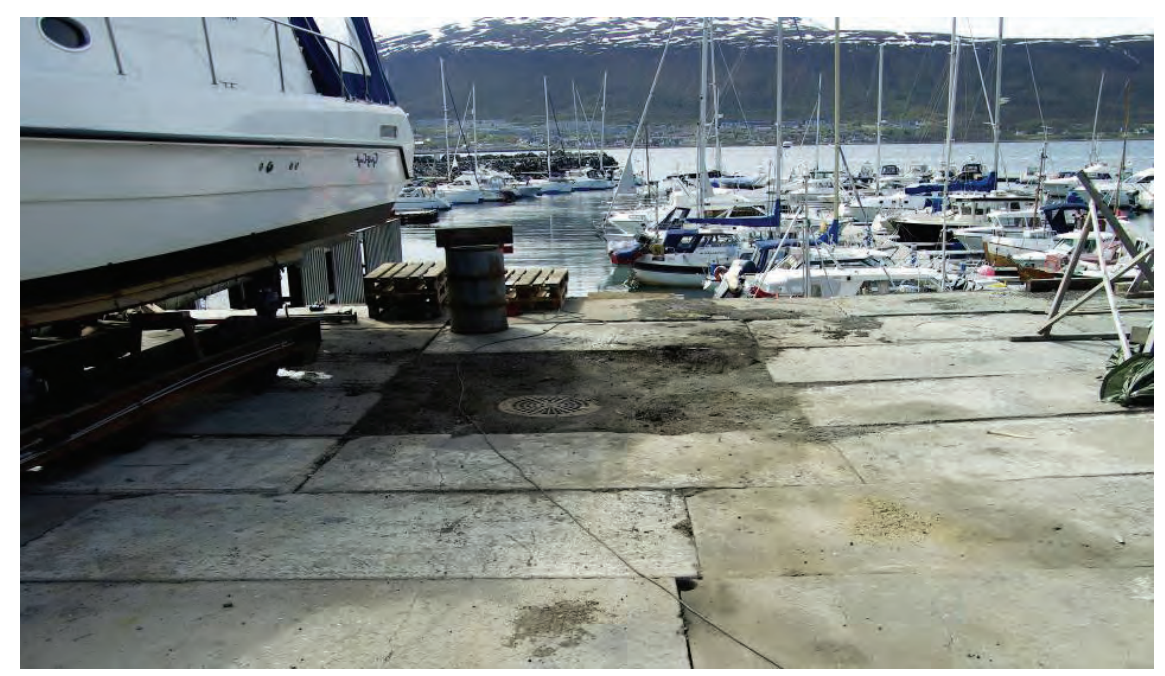

Mynd 12. Hellulagt planið á slip pstöð N3 hallar niður að skál með botnsfallsfrau ði fyrir frárennsli.

Eigandinn giskar á að u.p.b. $80 \%$ af frárennsli safnist parna fyrir pví hallinn að skálinni sé góður. Yfirfallsvatn úr skálinni leiðir beint út í viðtaka. Starfsfólkið segir tiltölulega lítið botnfa 11 hafa myndast í skálinni og hún hafi aldrei verið tæmd. Í áætlunum peirra kom fram að botnfallinu ætti að skila sem spilliefni. Botns fallsskálin var sett upp árið 2003, um svipað leyti og eiga ndinn tók vi ð fyrirtækinu. Hann gerði pað að eigi $n$ frum kvæði. Um hverfisvitund starfsmanna var með ágætum og peir voru almennt áhugasamir um að starfshættir væru eins umhverfisvænir og kostur er svo fram arlega sem k ostnaðurinn $r$ iði ekki f yrirtækinu á sli g. beir höfðu átt góð sam skipti við fulltrúa umhverfisskrifstofu sýslumannsembættisins pegar skálinni var kom ið fyrir, en höfðu aldrei fengið f yrirmæli um að kom a á búnaði til söfnunar á úrgangi. Hin s vegar var pekking u peirra á reglugerðum og skyldum peirra ábótavant. 


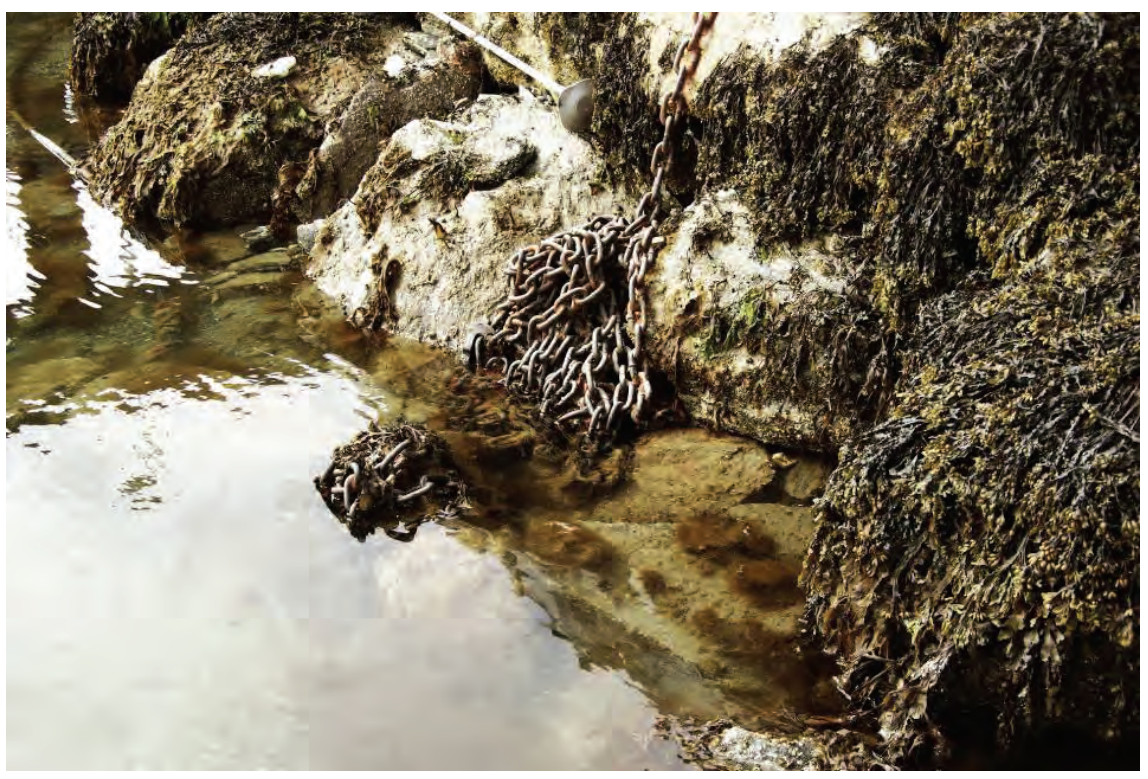

Mynd 13. Fjörumálið undir pvottaplani á slippstöð N3.

Eins og áđur kom fram er pvottaplanið par sem spúlun fer fram gert úr steyptum hellum. Á milli peirra eru mjóar rifur (u.p. b. 1-2 sm) par sem vatnið getur runnið í gegnum jarðveginn. Eigendurnir vöktu sjálfir athygli á pessu vandam áli. Peir sögðust hafa velt pví $\mathrm{f}$ yrir sér að heilstey pa planið, en óttuðust að frost ætti eftir að mynda sprungur í steypuna.

Afar sjaldan voru pað starfsmenn fyrirtækisins sem báru botnmálningu á bátana pví yfirleitt sáu bátaeigendurnir sjálfir u m pað verk. Fy rirtækið selur botnmálningu, aðallega af merkinu Hem pel, enda er sú tegu nd mest notuð hjá f yrirtækinu. Hin s vegar var allur gang urá bví h vaða tegundir bátaeigendurnir sjálfir no tuðu. Upplýs ingablöð um vörur pær s em eru seldar og notaðar á slippstöðin ni 1 águ framm i. Starfsmenn slippstöðvarinnar nota u.p.b. 50 lítra af botnmálningu á ári hverju. Ofan á pað bætist málning sem bátaeigendurnir bera sjálfir á bátana. Eigandi slippsins gerði sér grein fyrir að pvotturinn ætti alltaf að fara fram á plani fyrir ofan úrgangsskálina, en botnmálun fór einnig fr am á ý msum öðrum uppsátrum. Pekkingu var ábótavant um hvaða efni væru bönnu ð í botnmálningu og menn treystu pví að innflytjendur botnmálningar og annarra leysingaefna pekktu reglu gerðir og seldu pví aðein s lögleg efni. Pá var lítið vitað um reglugerðir um losun ef na út í umhverfið og ástæður f yrir banni við notkun ákveðinna efnategunda.

Eins og áður kom fram er slippurinn staðsettur í smábátahöfn. Fyrir neðan hann er reistur v eggur á mó ti fjörunn i. Punn o líubrák er i đulega á vat nsyfirborðinu f yrir i nnan brimbrjótinn, og stafar h ún líklega f rá af lknúinni eldsneytisdælu sem sér bátum fy rir dísel og bensíni. Slippurinn annast ek ki rekstur hennar. Parna verður oft vart við stórar torfur af smáfiskum.

Hjá fy rirtækinu og í bátahöfninni vor u vel m erktir gámar fy rir ýmis spilliefni. Par var einnig gámur fyrir annan úrgang (Mynd 14). 


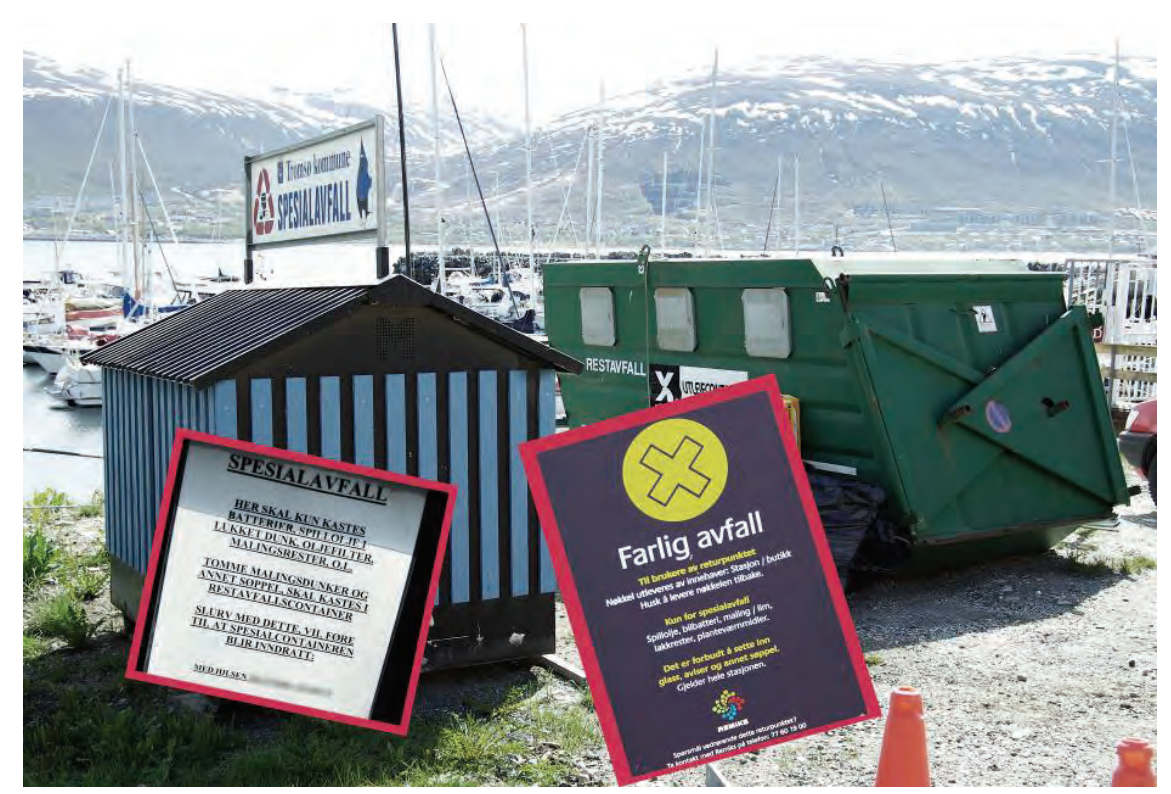

Mynd 14. Vel merktir gámar fyrir ýmsan úrgang á slippstöð N3.

Starfsmenn bátamiðstöðvarinnar og hafn arinnar upplýstu að oft py rfti að flokka úrgan ginn í gámnum fy rir almennan úrgan $g$ pví bátaeigendum hætti til að henda spilliefnum í hann. Sveitarfélagið sér u m að sækja almennan úrgang og spill iefni. Svæðið var tiltölulega sny rtilegt. Í byrjun pessarar aldar fékk fy rri eigandi fy rirmæli u m að taka til á lóðinni og fjarlægja olíumengaðan jarðveg af eigninni. Núve randi eigandi leggur áherslu á að snyrtilegt sé á eigninni.

\subsubsection{Norsk slippstöð, N4.}

Stutt var staldrað við á næstu slippstöð pví eigandi nn sá sér ekk i fært að taka pátt í könnu ninni. P ar var mikið um að vera (Mynd 1 5). P ar voru prjár grindur á teinum og dráttarvélar til pess að fly tja báta til á landi. Parna var sjálfsafgreiðsla og bátaeigendur sáu u m öll verk á meðan við vorum á stað num. Engin aðstaða virtist vera til að afhenda úrgang eða safna frárenn sli. Aftur á móti var töluvert um óflokkaðan úr gang sem hafði safnast saman víðs vegar á lóðinni (Mynd 16), og par voru opin ílát með úrgangsolíu (Mynd 17). 


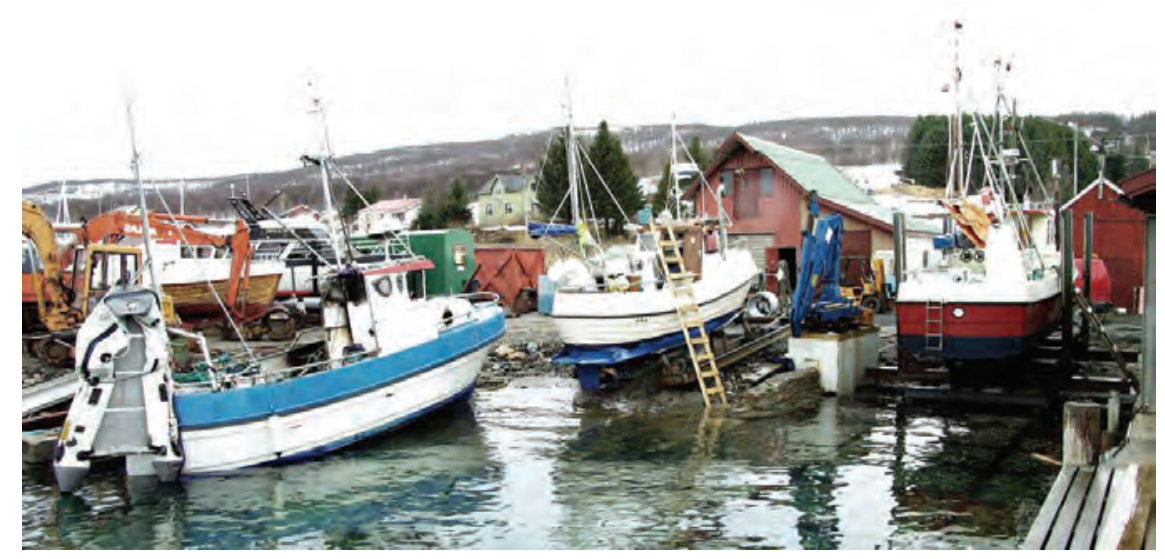

Mynd 15. Ys og bys á slippstöð N4.

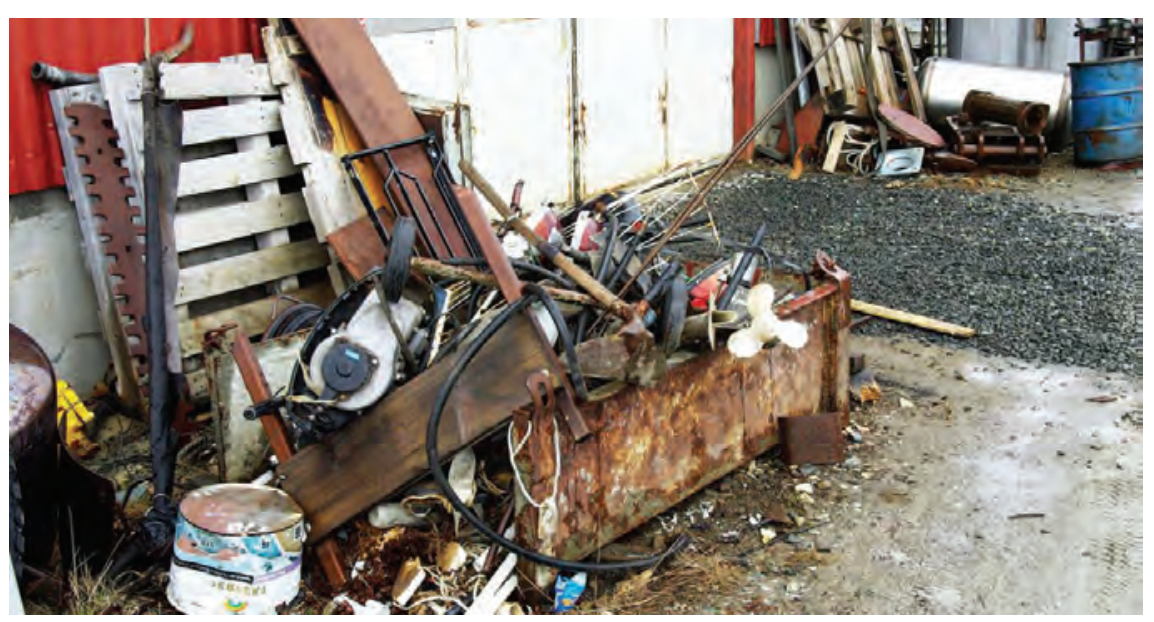

Mynd 16. Óflokkaður úrgangur á slippstöð N4.

Slippseigandinn hafði átt sam skipti við um hverfisstjórnvöld en aldrei fengið heimsókn eða fyrirmæli út af starfseminni. 


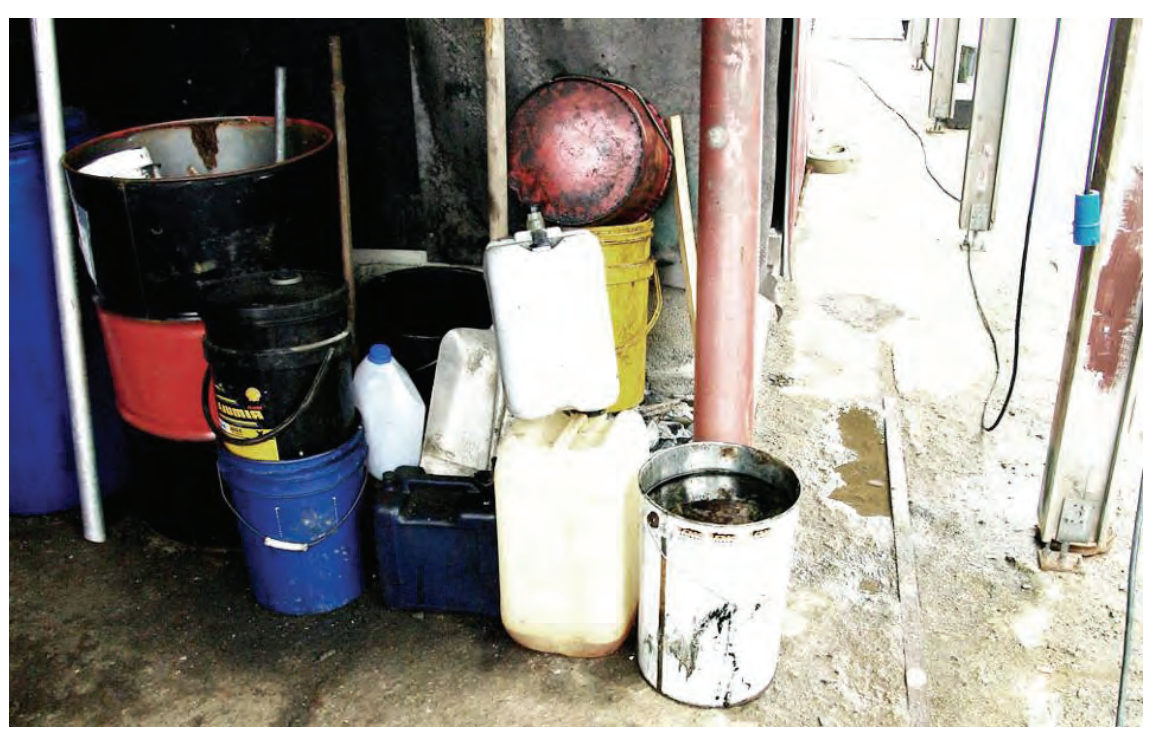

Mynd 17. Oliuúrgangur i opnum ílátum á opnu svceði á slippstöð N4.

\subsection{Litlar slippstöðvar á Álandseyjum}

Álandseyjar eru sjálfstjórnarsvæði í $\mathrm{F}$ innska ríkissam bandinu o g liggja suður af Helsingjabot ni (Mynd 18). Íbúar eyjanna eru u. p.b. 27.000, eyjarnar eru tæplega 7000, par af eru um 60 í by ggð. E ystrasaltið er eitt stærsta ís alta vatnasvæði hei $\mathrm{ms}$ og pa $\mathrm{r}$ ríkja $\mathrm{m}$ jög sérstakar vatn afræðilegar og vistfræðilegar að stæður. Vegna mikils seltumismunar myndast 60-80 metra saltskiptalag á stórum svæðum í Eystrasalti. betta takmarkar mjög endurn ýjun vatns á botni hafsins og veldur súrefnispurrð. Ey strasaltið er undi $r$ miklu álagi vegna $\mathrm{m}$ ikillar losunar á næringarsölt um og mengun frá landbúnaði , skólpræsum og iðnaði (HELCOM, 2004). Umhverfisástandið hefur batnað ör lítið á síðari árum (HELCOM 2008), en pó verða margar tegundir fyrir barðinu á um hverfisskaðlegum efnum og vistkerfið er pví sérlega viðkvæmt fyrir pví að fleiri skaðleg efni berist í hafið. 


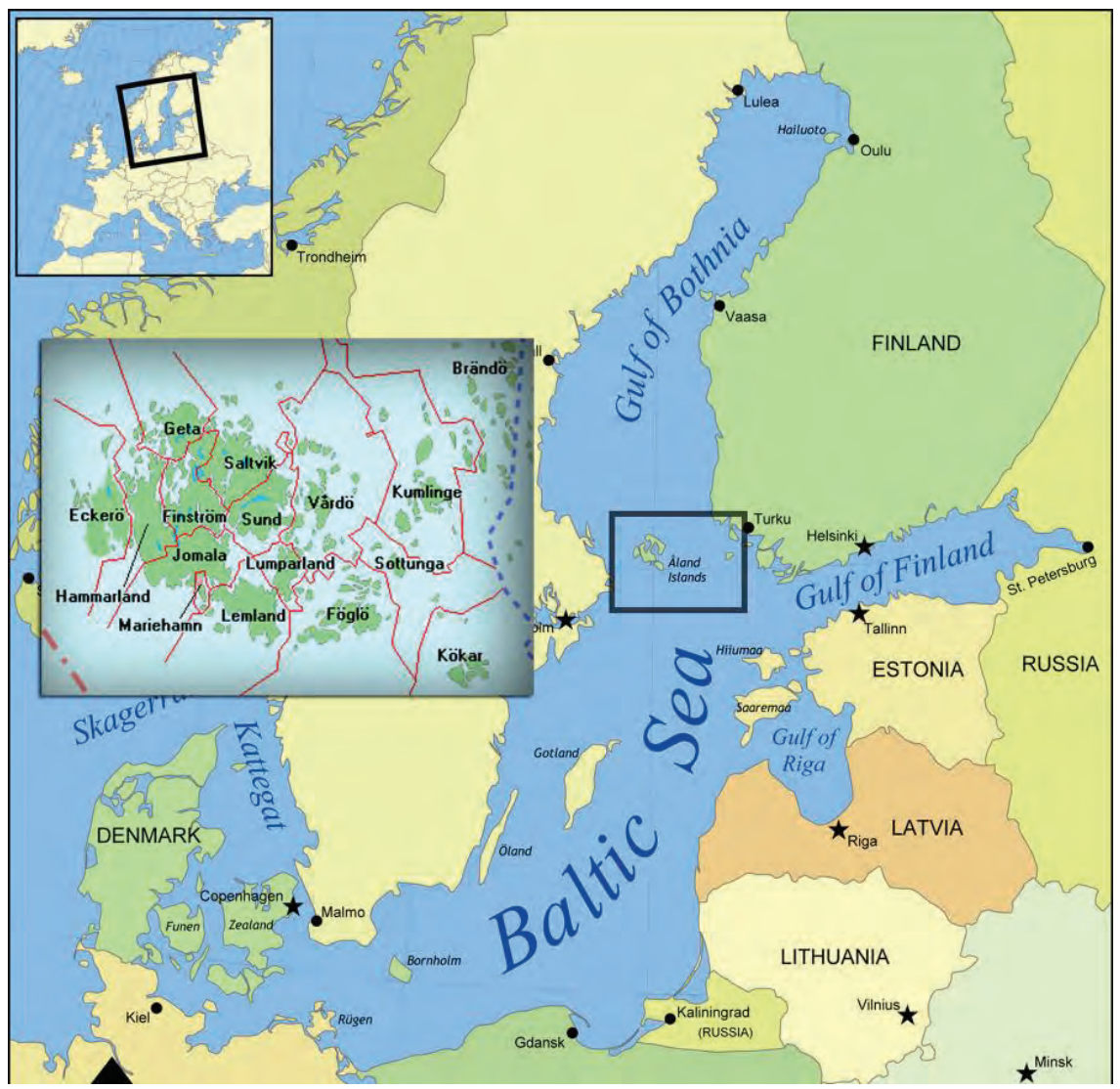

Mynd 18. Álandseyjar liggja við mynni Helsingjabotns.

Mjög lítill munur er á fló ði og fjöru við Álandsey jar og pví lítið u m hafstrauma sem berast með sjávarföllum. Almennt er lítil endurnýjun vatns umhverfis slippstöðvarnar. Fjöldi íbúa er ekki mikill en mjög margir peirra eiga báta. Í viðtölunum kom fram að margir sænskir bátaeigendur kjósa að koma til Álan dseyja til að kaupa bot nmálningu sem inniheldu r kopar (se m er bönnuð í Svípjóð) eða til að láta botnverja báta sína.

Leitast hafði verið eftir heimsóknum á fimm slippstöðvar og var farið á prjár peirra. Í slippi í Maríuhöfn var okkur meinaður aðgangur og menn voru heldur til viðræðu um umhverfismál í tengslum við slippstöðvar og smábáta. Á öðrum stað var okkur ekki leyft að taka ljósmyndir brátt fyrir að nafnleynd væri lofað í skýrslunni.

\subsection{1 Álensk slippstöð, Å1}

Slippurinn er í strjálbýli við opið s und á sunnarlegum Álandsey jum, en í nágrenni péttbýlis (Mynd 19). Slippstöðin hefur verið rekin um áraraðir og par starfar nú aðeins einn maður. Öll starfsem i fer fram á sumarmánuðum og viðski ptavinirnir eru aðal lega ferðam enn. Баð eru jafnan skemmtibátaeigendur sem eiga par leið um. 


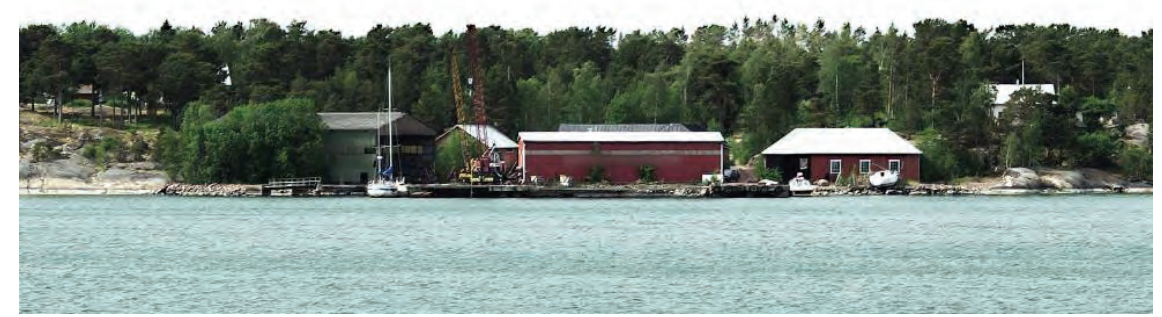

Mynd 19. Slippstöð Å1 séð frá hafi.

Á slippstöðinni eru prjár grindur á teinum og færanlegur krani til að ly fta bátum. Fyrirtækið tekur u.p.b. 20 bá ta á hverju sum ri og sér aðallega um viðgerðir á bátskrokkum og útbú naði. Okkur va $r$ tjáð að par væri hverfandi lítið um pvott og botnm álun. Menn giskuðu á að árlega færu um 50 lítrar af botnmálningu af norsku tegundinni „Norrøn“.

Fyrirtækið he fur ekki búnað til að safna spilliefnum. Úrgangsolíu er safnað í 200 lítra ker sem hefur ekki verið tæmt í 5 ár.

Staðurinn bar vott um lélegt við hald, úrgangur og bátshræ lágu á ví og dreif, bæ đi á landi og í sjó ( $M$ ynd 20). Okkur tókst ekki að kanna strandsvæðið nánar bví nærveru okkar var greinilega ekki óskað.

Fyrirtækið h efur ekki átt samskipti við um hverfisstjórnvöld á staðnum. Y firm aðurinn vi rtist ágætle ga upp lýstur og var gagnrýninn á stefnu um hverfisstjórnvalda. Okkur v ar ekki le yft að taka myndir í slippnum á meðan á heimsókninni stóð. Myndin sem hér eru birtar voru teknar fyrir utan slippstöðina.

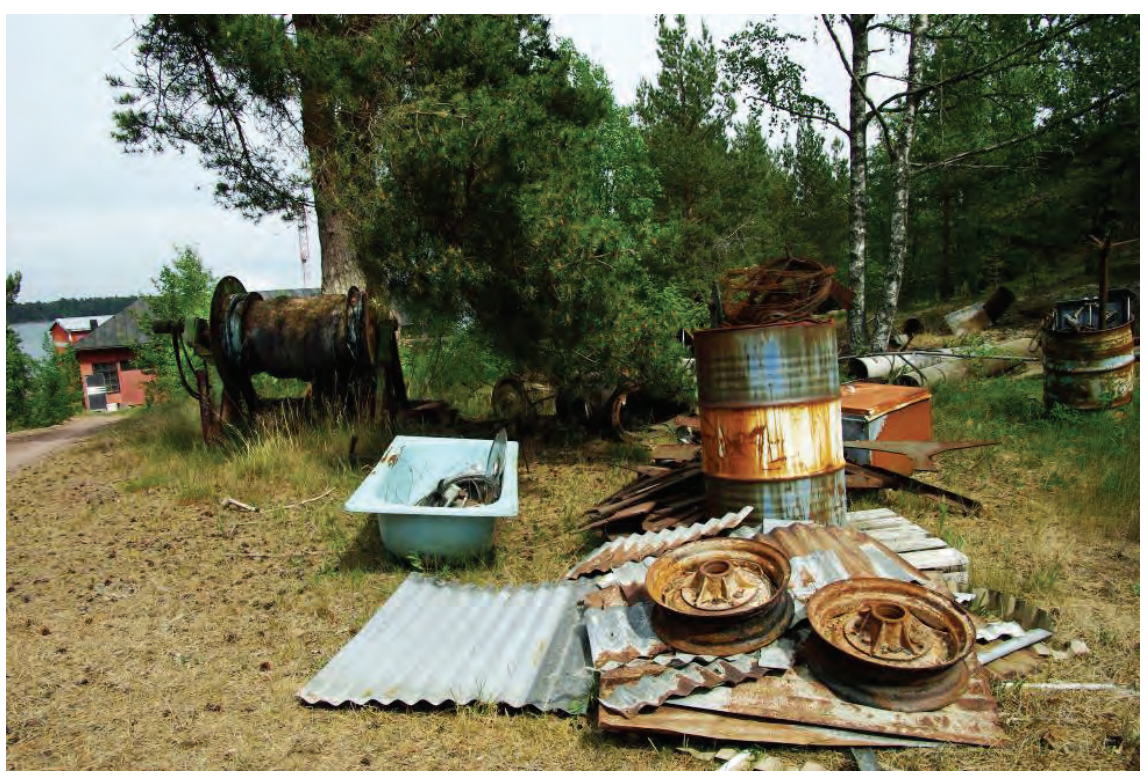

Mynd 20. Úrgangur við innkeyrsluna að slippstöð Å1. 


\subsection{2. Álensk slippstöð, A22.}

Fyrirtækið er staðsett í fámennu by ggðarlagi á sunnarlegum Álandseyjum. Einyrkjafyrirtækið annast aðall ega viðgerðir og viðhald. Dráttarv él dregur bátana á grind á hjólum upp á plan með möl og steypu (Mynd 21).

Slippstöðin tekur um 30 báta á hverju ári og vi nnan fer að mestu fram á vetrarmánuðum. Fyrirtækið sinnir bát um heimamanna en peir eru yfirleitt af stærðinni 20-30 fet.

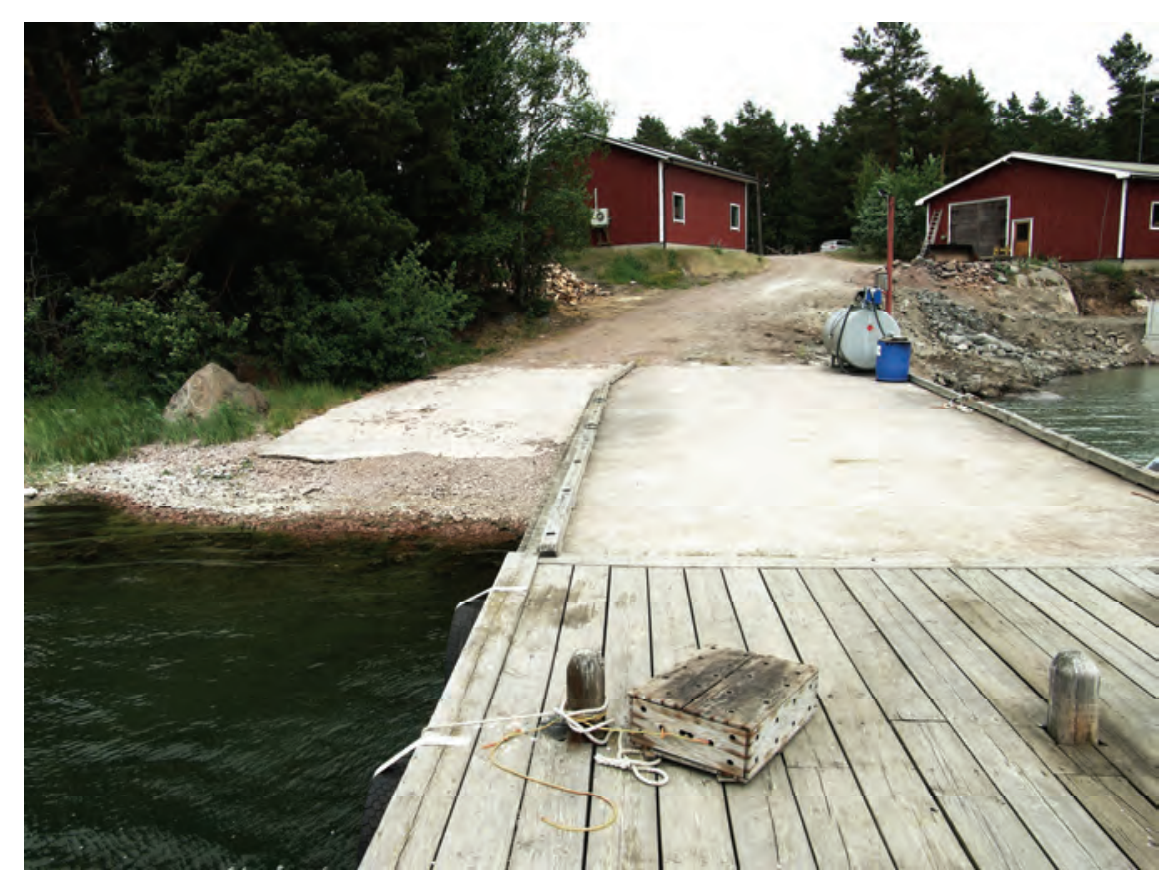

Mynd 21. Br yggja og plan fyrir uppsátur ás lippstöð Å2 par se m bátar eru dregnir á vagni à hjólum.

Bátunum er ýmist lagt utanhúss (My nd 22), eða í opnum skúr eða vörugeymslu, par sem peir eru geymdir og dyttað að peim (Mynd 23). Hvergi sáust auglýsingar eða gámar fyrir spilliefni.

Svæðið var allt sny rtilegt og engi nn vottur um úrgang eftir pvott / botnmálun $\mathrm{b}$ áta prátt $\mathrm{f}$ yrir að frárennsli og $\mathrm{m}$ álningarleifum sé spúlað beint út í sjó. Eigandi fyrirtækisins sér um flest verk. 


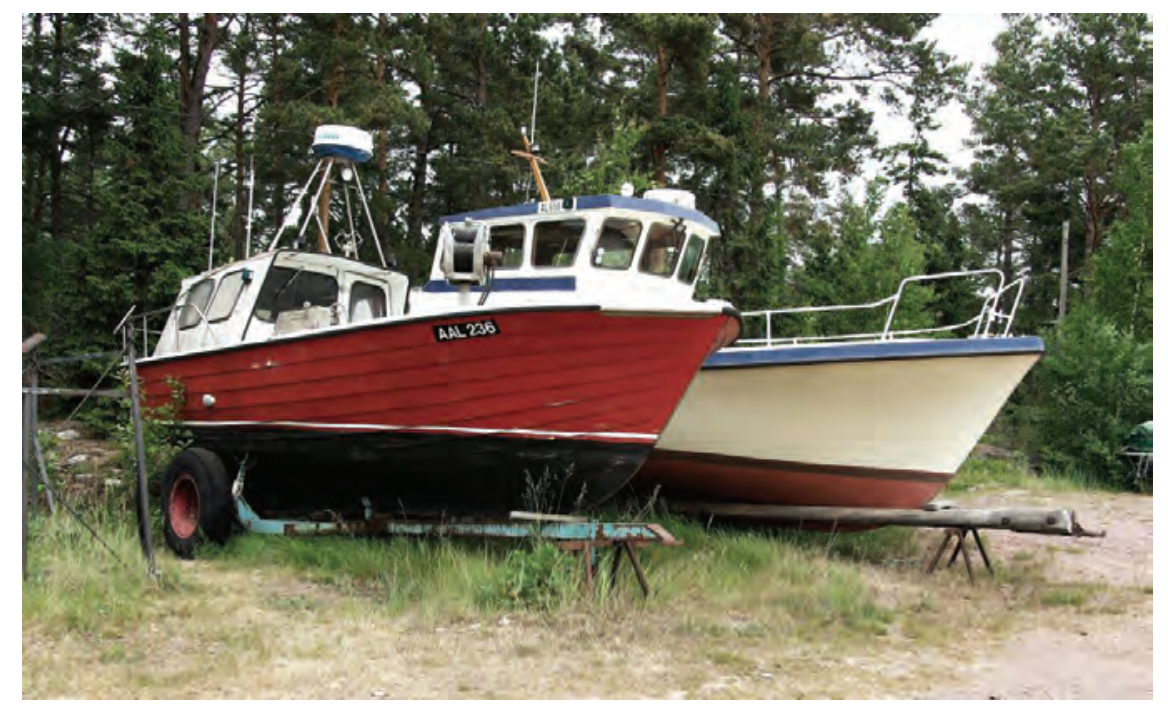

Mynd 22. Bátageymsla fyrir utan slippstöð A2.

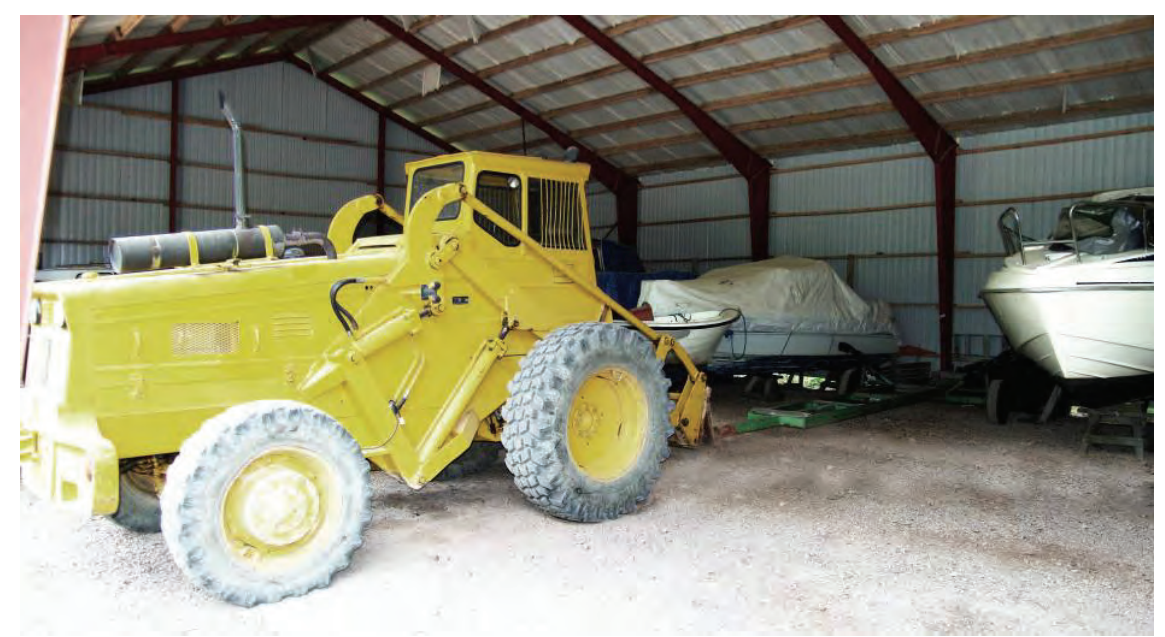

Mynd 22. Dráttarvél með bátavagni i vörugeymslu fyrir báta á slippstöð A2.

Fljótt á liti ð virtist fjör uborðið ekki bera nein verksummerki eftir starfsemina (Mynd 24).

Eigandi slippsins var jákvæður í garð umhverfisvæns reksturs og vissi eitthvað lítils háttar um reglur, hættuleg efni og skaðleg áhrif peirra. 


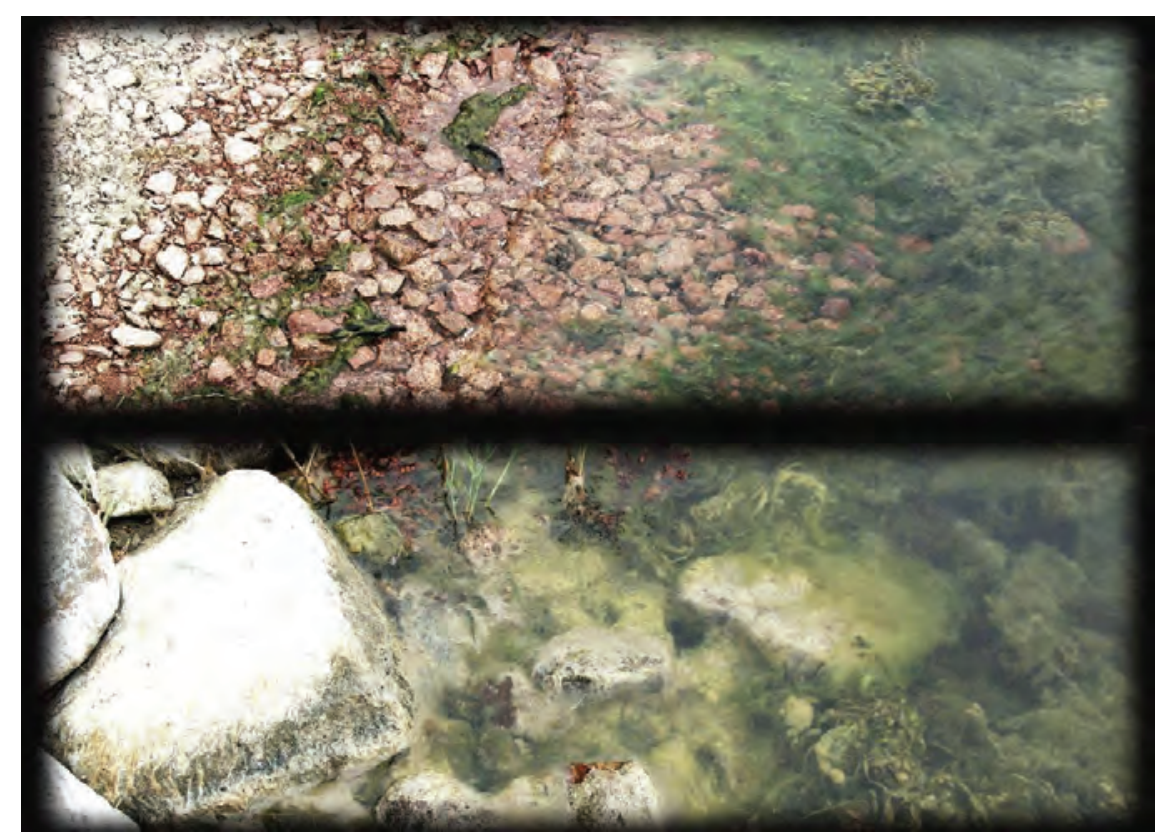

Mynd 24. Mynd úr flceðarmáli fyrir neðan uppsátur (efri mynd) og við hliðina á uppsátri (neðri mynd) á slippstöð Å2.

\subsection{3. Álensk slippstöð, Å3}

Fyrirtækið liggur í vari bak við tvo br imbrjóta í péttbýli á Álan dseyjum við hliðina á opnu sundi. Um er að ræða einy rkjafyrirtæki við s mábátahöfn. Par er aðstaða til að tæm a fastan og flj ótandi úrgang, eldsney tisdæla, uppsát ur og pjó nusta á vélum og bátskrokk um. Fyrirtækið sér u m ýmsa pjónustu, par á m eðal vetrargeymslu fyrir skemmtibáta sem margir eru í eigu heimamanna.

Bátarnir eru teknir á land með sérstakri lyftu par sem peir eru slússaðir á land milli tveggja bryggjusporða (Mynd 24; Mynd 26).

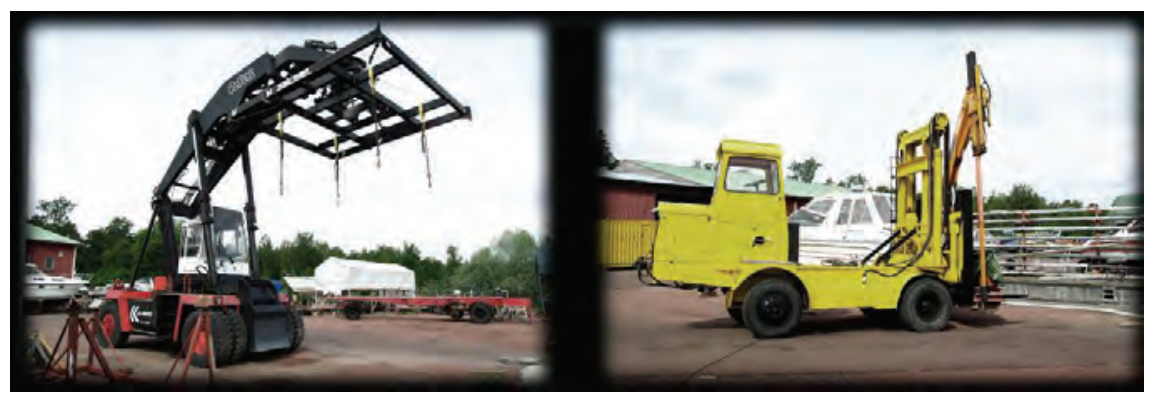

Mynd 25. Lyftari til að lyfta bátum i uppsátur og masturslyftari á slippstöð Å3. 


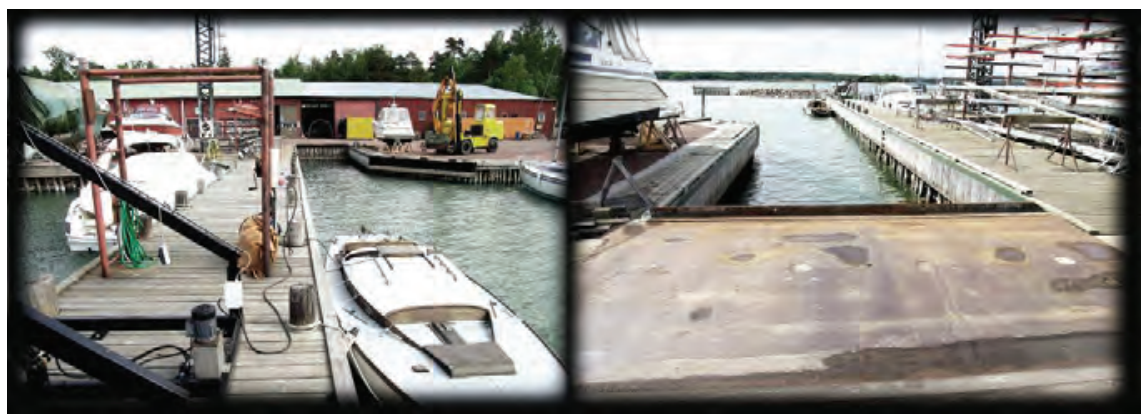

Mynd 26. Bryggja eða gátt til að taka bát með masturslyftara á slippstöð A3.

Um 200 bátar, aðallega af stærðinni 20-33 fet, eru spúlaðir og botnvarðir á hverju ári. Um 5\% peirra eru skrapaðir/slípaðir, með eða án iðnaðarryksugu. Í örfáum tilvikum eru bátarnir hreinsaðir með sandblæstri (u. p.b. 1 bátur á hverri vertíð).

Frárennsli með úrgangi rennur óhreinsað út í sjó. Öllum öðrum úrgangi er safnað saman á vel skipulagðri söfnunarstöð (Mynd 27; Mynd 31).

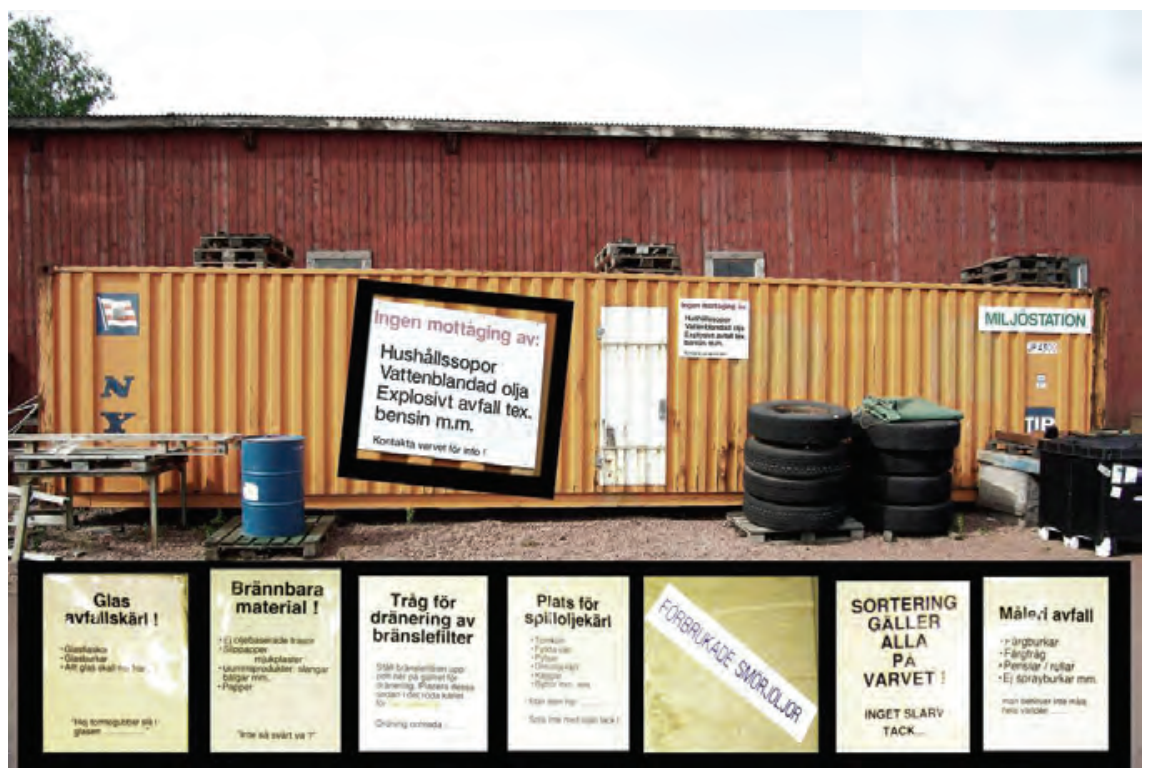

Mynd 27. Söfnu narstöð úrgangs sem hæegt er að laesa, og sýnishorn af útskýringum á safngámum (inni á mynd og undir). 


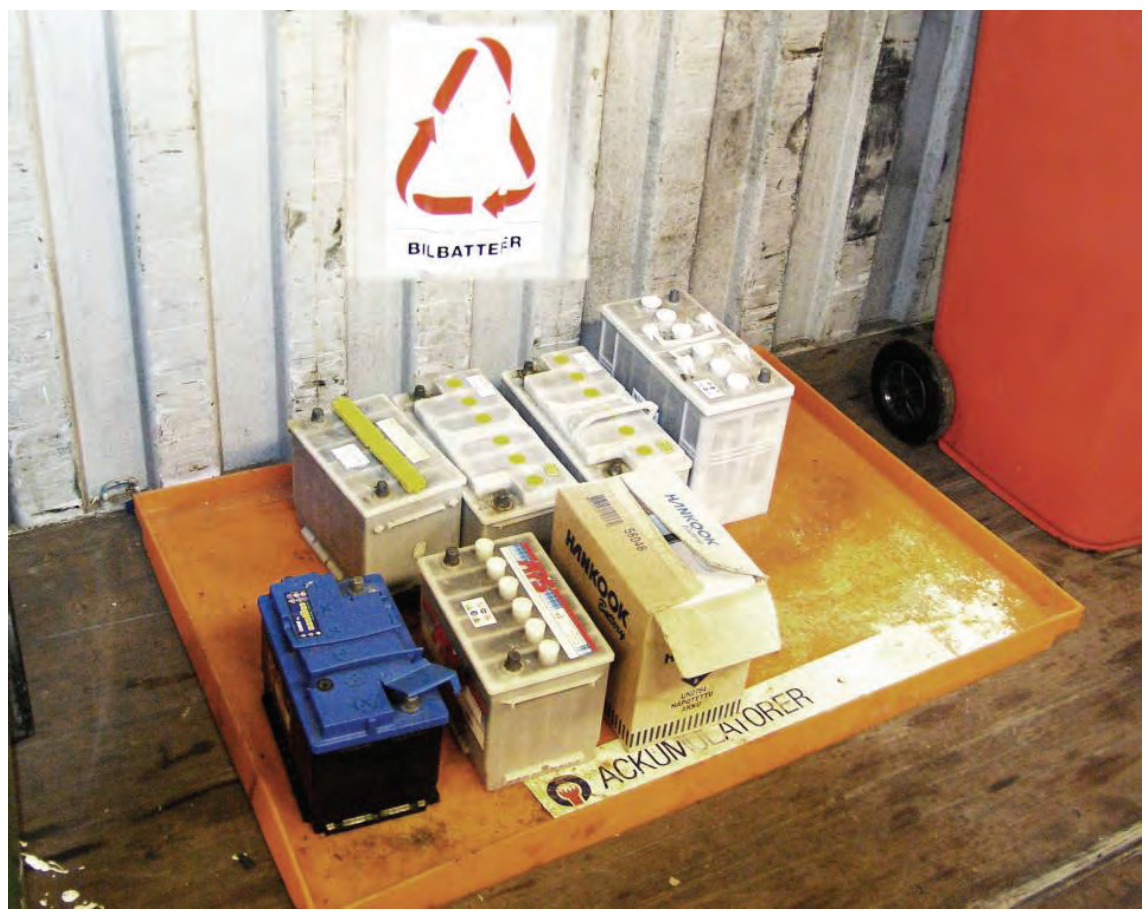

Mynd 28. Söfnunarbakki fyrir notaðar rafhlöður, slippstöð A3.

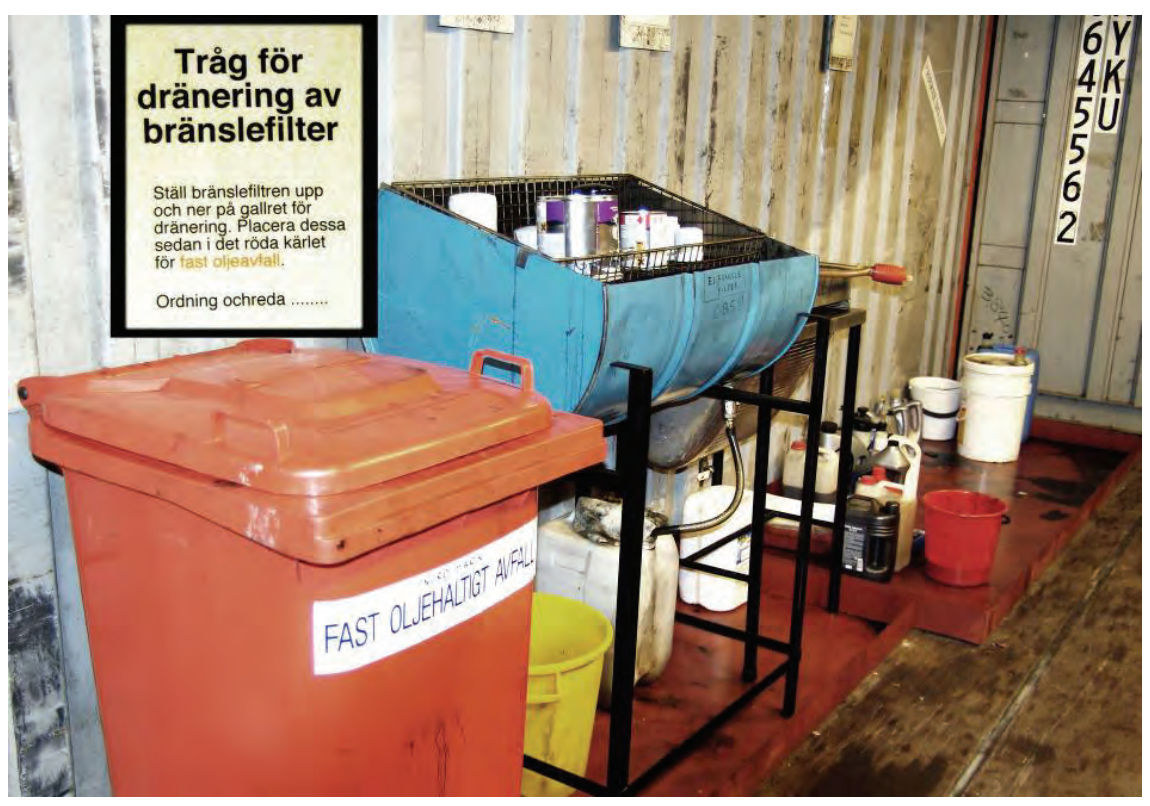

Mynd 29. Afrennslisker fyrir olíu á slippstöð Å3. 


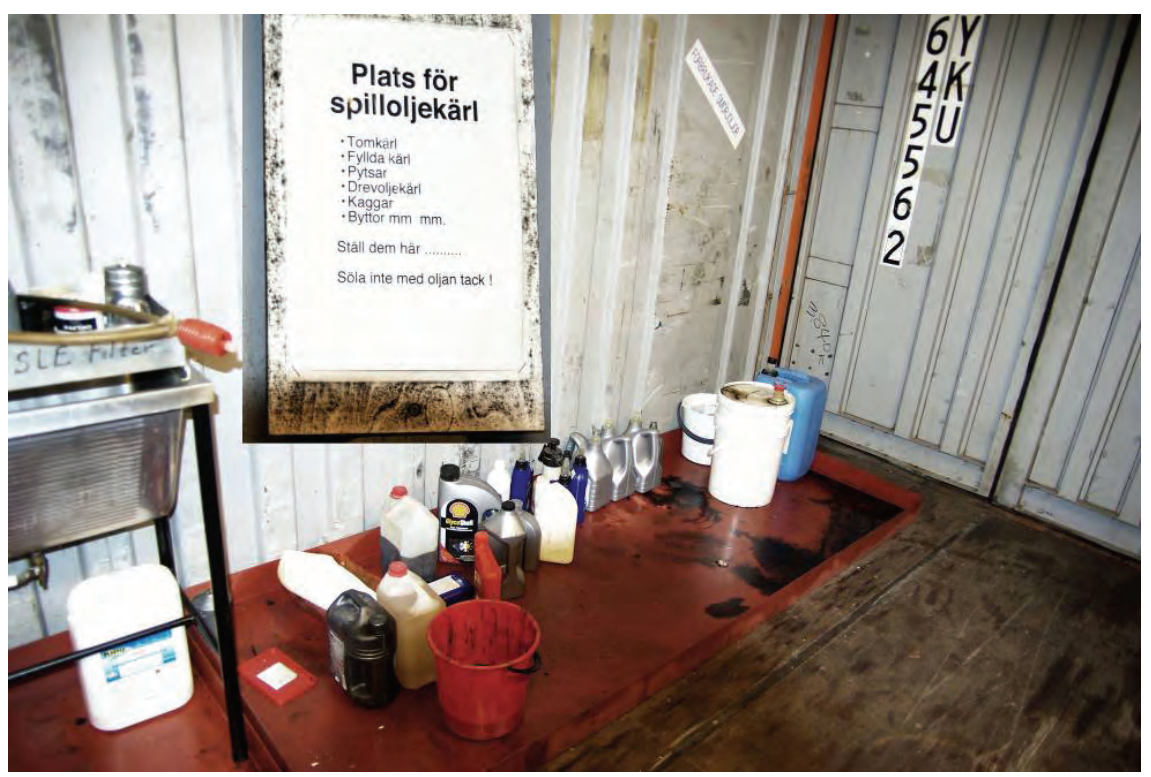

Mynd 29. Söfnunarker fyrir tómar og fullar könnur af úrgangsolíu á slippstöð Å3.

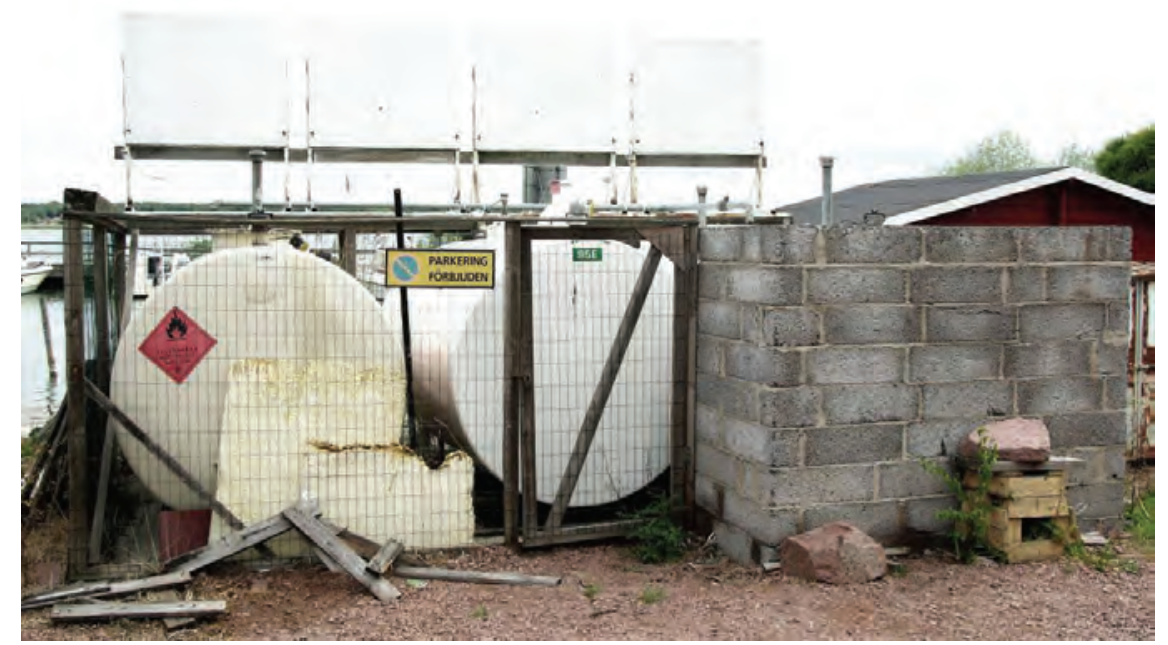

Mynd 31. Safngeymir fyrir oliu og annan fljótandi úrgang á slippstöð A3.

Eigandinn kvaðst eiga góð samskip ti við um hverfisstjórnvöld og virtist reka fy rirtækið á $m$ jög um hverfisvænan hátt að eigin frum kvæði og án íhlutunar stjórnvalda. Par var gr einilega haldgóð pe kking á $m$ engandi efnum. Eigandinn virtist leggja sig fram um að rekstur fy rirtækisins væri samkvæmt settum reglum. Pó vor u engin áform u m söfnunarplan fy rir frárennsli (prátt fy rir að aðstæður væ ru fy rir hendi). Fy rirtækið hy ggst reyndar koma sér upp búnaði til pvotta á botnum bátskrokka í vatni (pannig botnpvottur kæmi í stað spúlunar og notkun ar á gróðurhindrandi málningu). 
Miðað við aðra staði sem við heimsóttum er óhætt að segja að flokkun og geymsla á spilliefnum hafi verið til fyrirmyndar. Pó skorti hér eins og annars staðar búnað til að safna og hreinsa frárennsli.

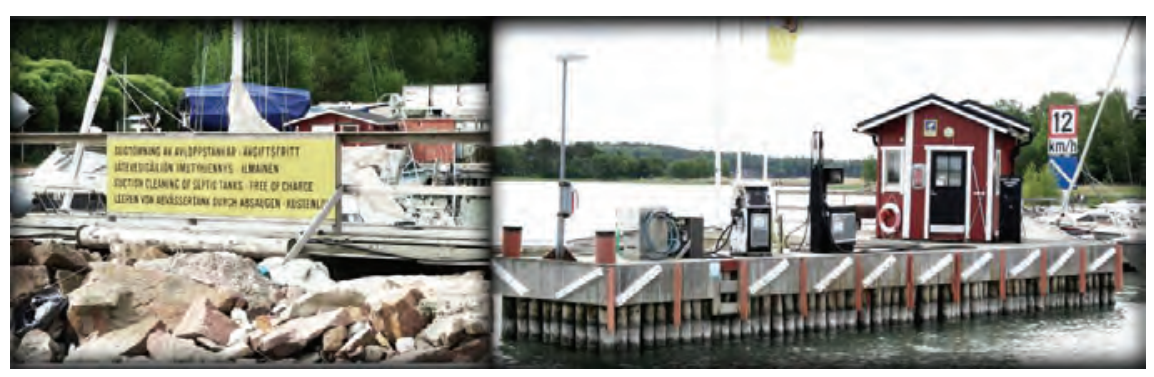

Mynd 32. Upplýsingaspjöld og eldsneytisdcela við innsiglingu bátahafnar/slippstöðvar Å3.

\subsection{Litlar slippstöðvar Færeyjum}

Færeyjar eru 18 eyjar í Norður-Atlantshafi sem eru umkringdar opnu hafi á alla vegu (Mynd 33). Í búar eru um 50.000, par af búa um 17.000 á Pórshafnarsvæðinu.

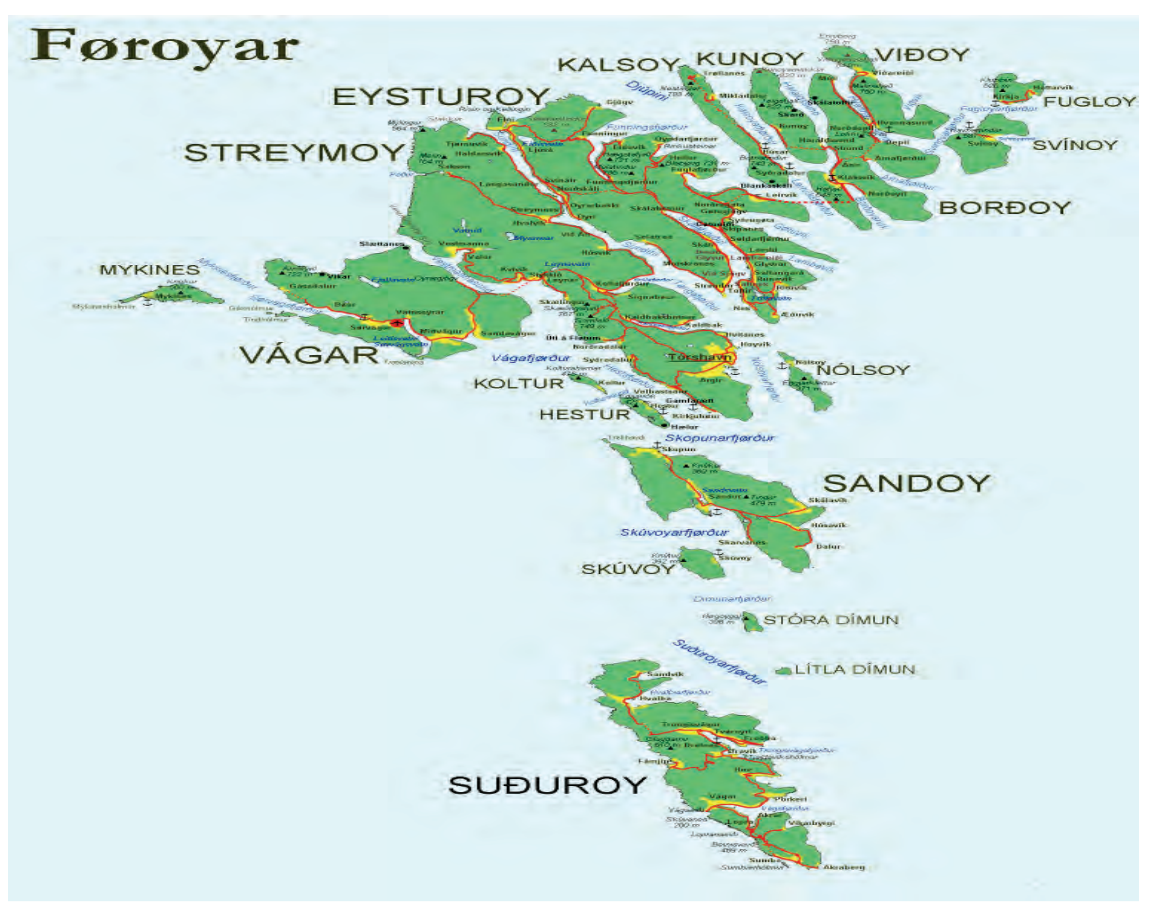

Mynd 33. Kort af Fareyjum.

Eyjarnar liggja nokkuð bétt og flestar eru vogskornar með löngum mjóum fjörðum, byg gð er dreifð og byggðarlögin misstór. Í flestu m fjörðum er a.m.k. ein stór laxeldisstöð. Um hverfisástand hafsins umhverfis Færeyjar er almennt gott. 
Tengiliður v erkefnisins hjá færey skum u mhverfisstjórnvöldum gaf okkur lista með 11 slippstöðvum af ýmsum stærðum. Við völdum eina litla slippstöð (4-5 starfsmenn) og tvær meðalstórar (15-20 starfsmenn) á premur eyjum. Meðalstór fyrirtæki urðu fyrir valinu vegna pess að fulltrúi umhverfisstjórnvalda á staðnum óskaði eftir nánari upplýsingum, en fá gögn liggja fyrir um slippstöðvar í Færeyjum frá fyrri könnunum.

\subsubsection{Fareysk slippstöð, F1}

Fimm manns starfa á slip pstöðinni sem er í lítilli byggð við m ynnið á löngum og mjóum firði. Fiskeldi er stundað í firðinum.

Fyrirtækið annast aðallega vélaviðhald, en fyrirtækið býður einnig upp á málningarvinnu og botnvörn. 50-60 bátar eru teknir á land á ári hverju, par af er um 5 stærri en 35 fet en annars eru peir á bilinu 20-35 fet. Fyrirtækið annast aðallega pjónustu við fiskveiðiskip og fiskeldi.

Á slippstöðinni er grind á teinum sem festir eru á steypt plan samhliða flæðarmálinu. Um hverfis planið er fjara með skeljasandi (My nd 34). Slippurinn getur tekið tvo 30 feta báta í einu.

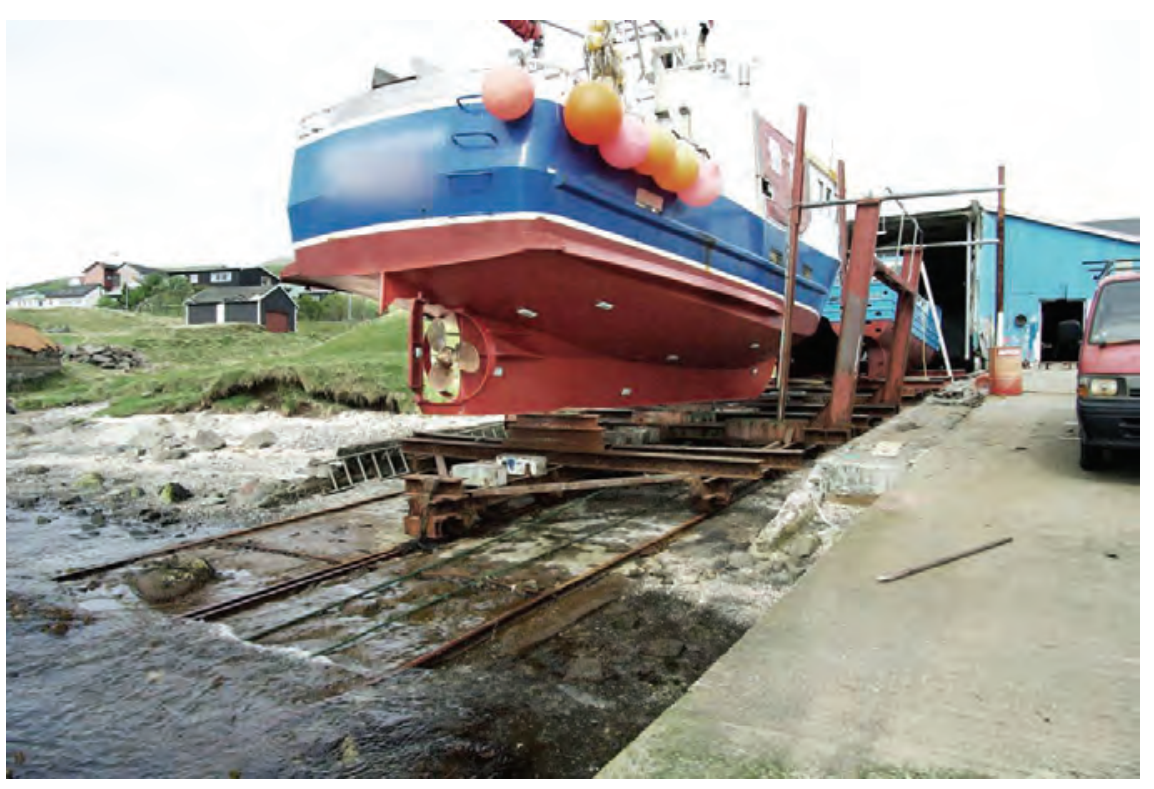

Mynd 34. Slippstöð F1: Grind á teinum á steyptu plani.

Við botnvörn er eingöngu háprýstispúlað og málað með gróðurhindrandi málningu. Bo tninn er stun dum meðhöndlaður með tveggja pátta epoxýmálningu en y firleitt aðeins pegar sk rokkurinn er illa farinn. Fy rirtækið giskar á að um 200 lítrar af gróðurhindrandi m álningu séu notaðir á ári hverju.

Par er engin aðstaða til að safna frárennsli eða úrgangi eftir hreinsun og málun á bátum eða ef olíuúrgang ur fer niður af sly sni. F yrirtækið íhugar ýmsar leiðir til að safna frárennsli eftir hábrýstipvott á bátunum. 
Okkur var tjáð að skeljasandur sem safnast fyrir neðst í slippnum væri fjarlægður öðru hverju. Sandurin n er pá ekki fluttur á hentuga gey mslustöð heldur urðaður í nágrenninu. Sa ndurinn er ekki fjarlægð ur út a $\mathrm{f}$ umhverfisskaðlegum efnum sem í honum leynast heldur vegna $r$ ekstraröryggis á grindinni.

Olíuúrgangi er safnað í ómerktar tunnur (Mynd 35), en pær eru sóttar eða afhentar á m óttökustöð sveita rfélagsins (IRF). Málm um, einkum notuðum forskautum úr sinki, er safnað sam an og peir seldir í bræðslu. Annar málmúrgangur er hvorki flo kkaður kerfisbundið né afhentur til endurvinnslu.

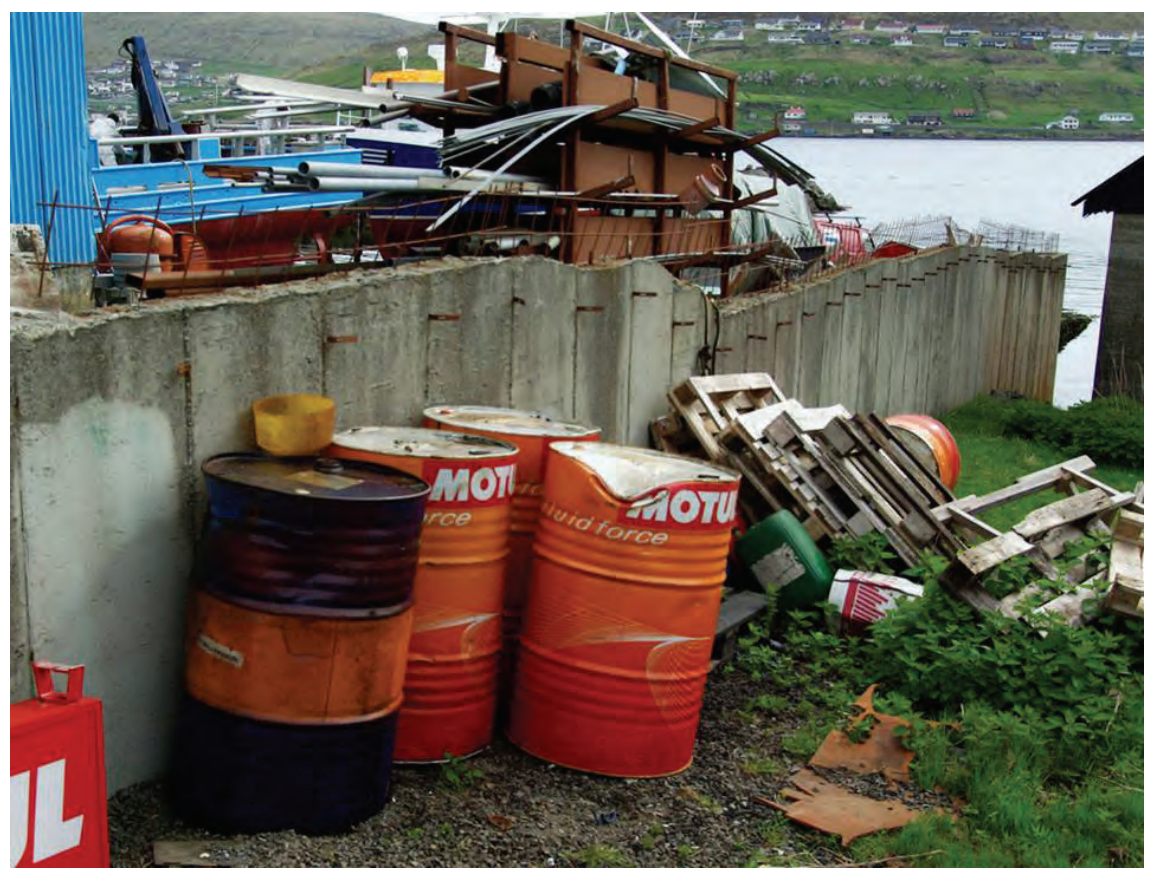

Mynd 35. Tunnur til að safna úrgangsolíu.

Málningin sem var notuð sem botnvörn er aðallega hörð gró ðurhindrandi málning af merkinu Hem pel (My nd 36). Yfirm anninum var ljóst að mengandi efni væru notuð á staðnum og vissi hvar hægt var að nálgast upplýsingablöð um vörur nar á netinu. Hann vissi hins vegar lí tið um reglur, hvaða efni eru eitruð o g hvaða eitrunaráhrif pau hafa. Aðspurðu r að pví hv ort hann teldi botnvörnina sem hann no tar ley filega, sagðist hann treysta pví að söluaðilinn (innflytjandi Hempel-málningar við skipasmíðastöðina í Pórshöfn) flytti aðeins inn leyfileg efni.

Eigandanum er um mun að vald a ekki mengun um hverfis og ós kar eftir samráði við aðila sem búa yfir fagpekkingu og umhverfisstjórnvöld. Honum fannst skorta upplýsingar og starfsreglur sem hægt væri að fylgja. 


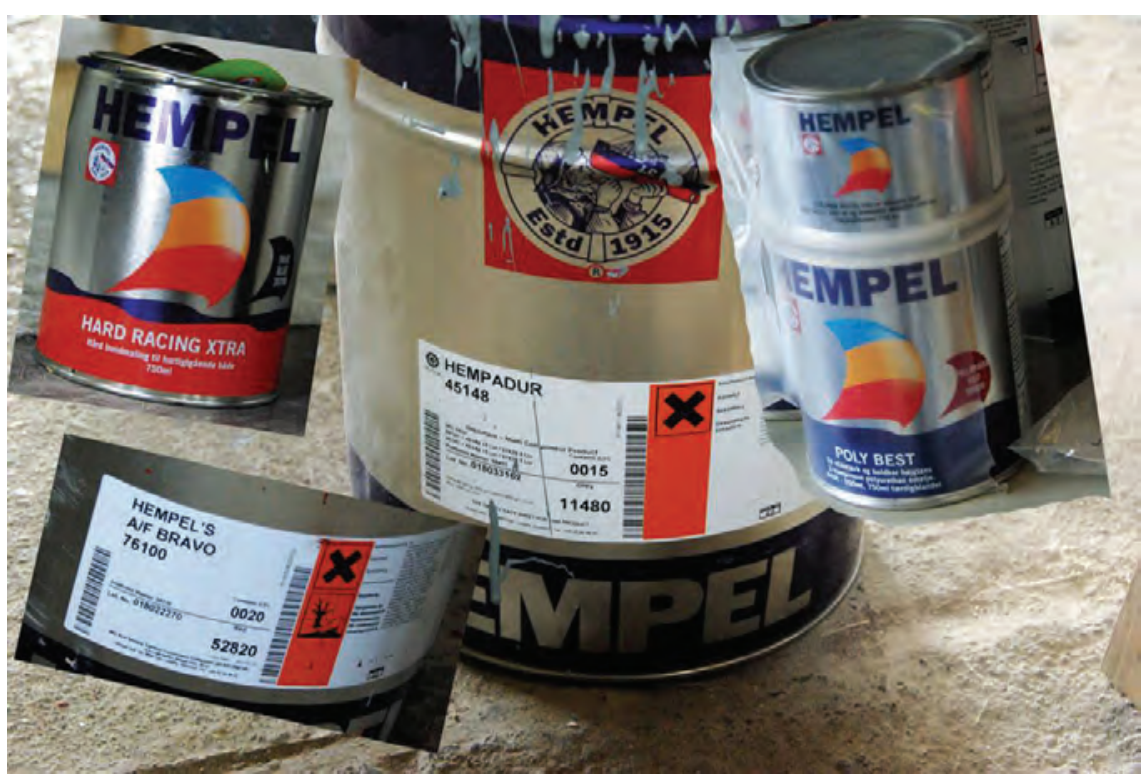

Mynd 36. Nokkur efni sem notuð eru á slippstöð F1.

Engin sýnileg merki voru um úrgang frá starfseminni í flæðarmálinu, gróður og dýralíf virtist sambærileg svipuðum ósnertum svæðum (Mynd 37).

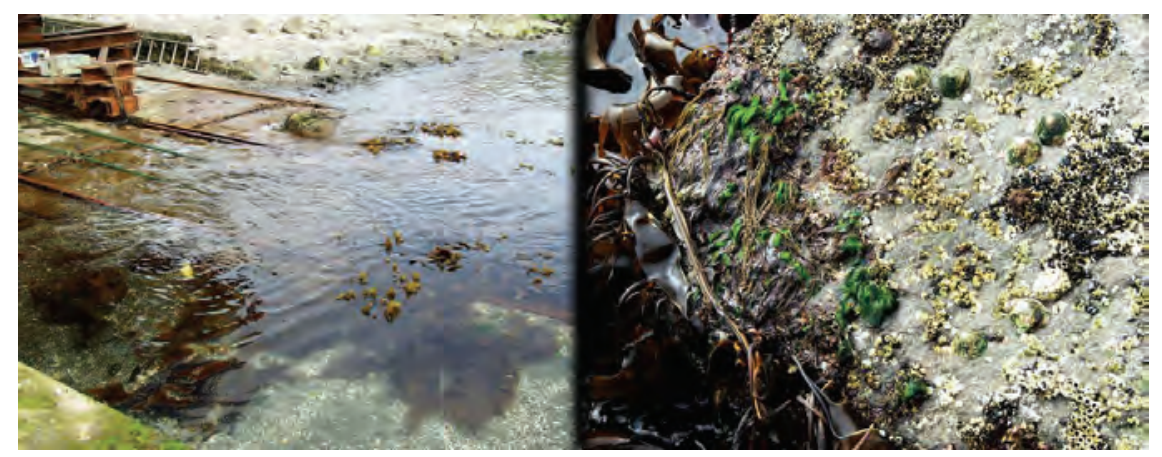

Mynd 37. Beltispari (Saccarina sp.) vex rét $t$ u ndir yfirborði, i fjörunni rét thj á vaxa brúnpörungar (Laminaria sp.), fjöloerar pyrpingar hrúðurkarla (Balanus sp.) og hnéskel (Patella sp.)

Fái fy rirtækið fy rirmæli u m að gera ko stnaðarsamar brey tingar á starf sháttum vegna um hverfisverndarsjónarmiða gera menn ráð fy rir að sama gildi um aðra í söm u og s vipuðum atvinnugrein um. Í pví sambandi var sérstaklega bent á óskipulagt viðhald á bátum sem fer fram á stórum landfyllingum/plönum par sem bátunum er lyft m eð hrey fanlegum krönum (Mynd 38-40). Yfirmaður fyrirtækisins gæti vel hu gsað sér vottun arkerfi fyrir alla slíka starfsemi. 


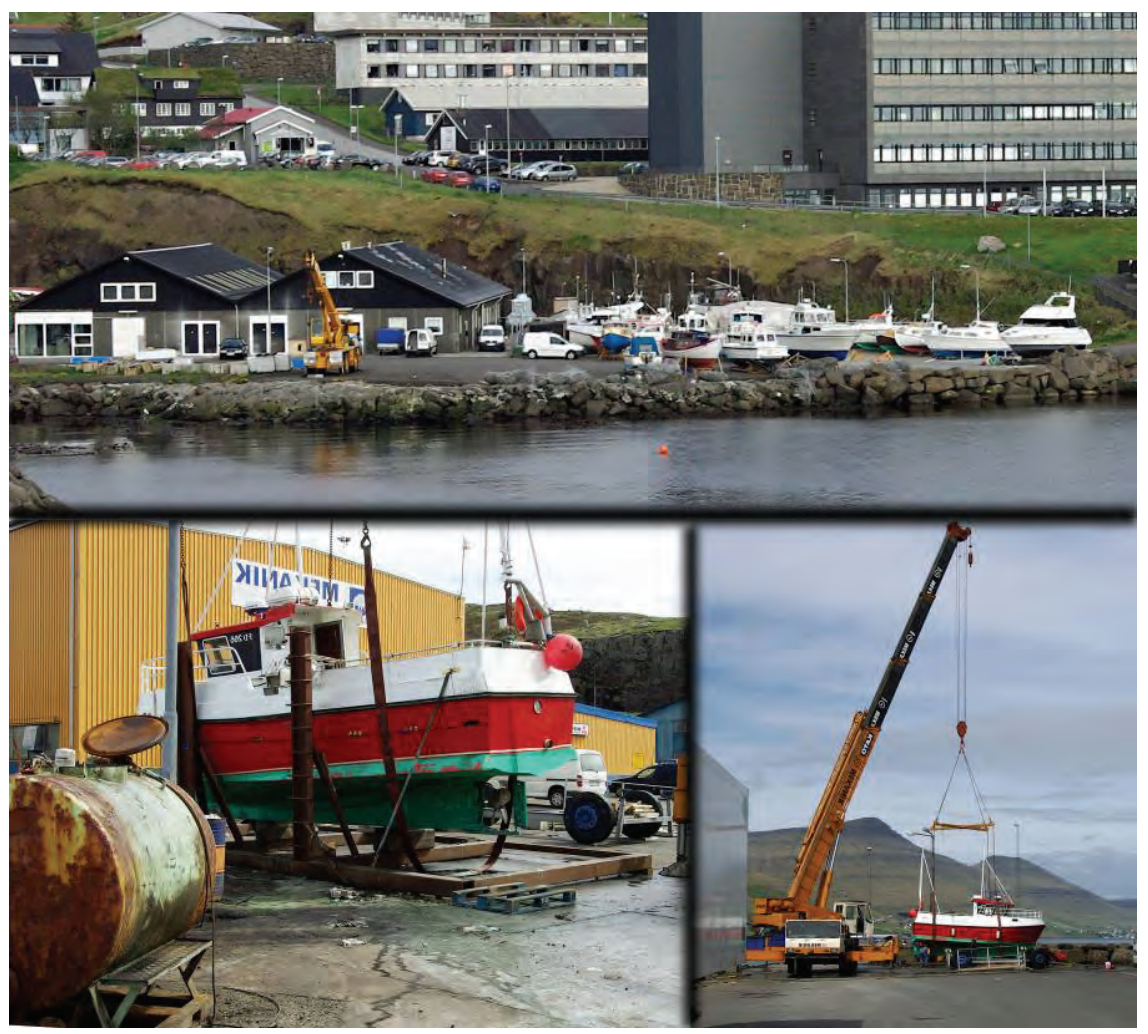

Mynd 38. Fceranlegur krani lyftir báti upp á bryggju.

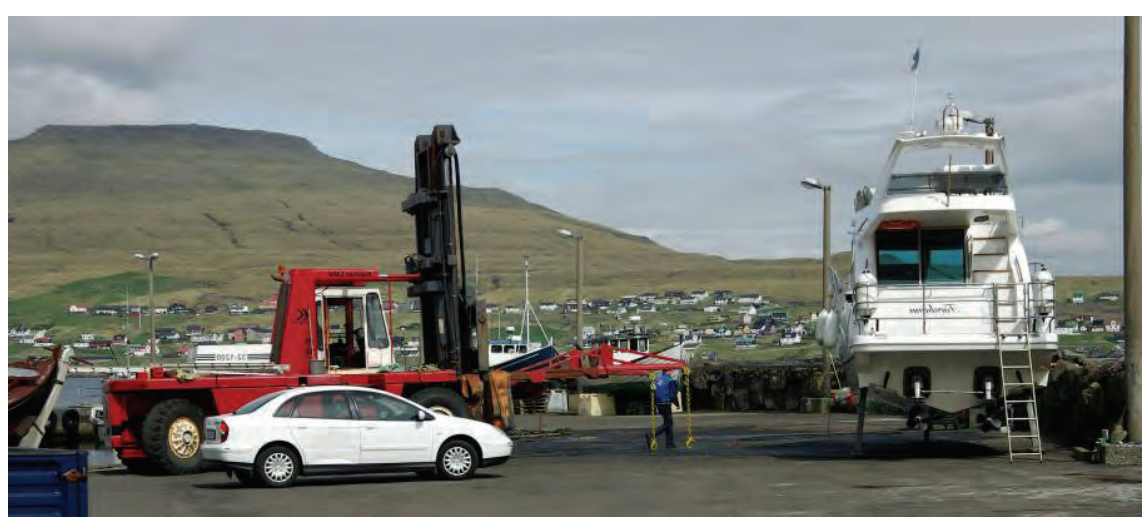

Mynd 39. Plan par sem bátum er lyft með lyftara (Fcereyjar).

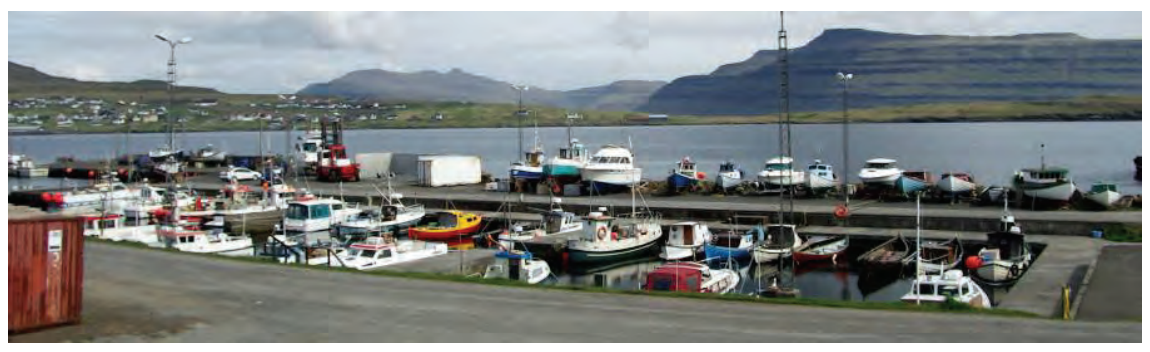

Mynd 40. Uppsátur á bryggju (Fcreyjar). 


\subsubsection{Fareysk slippstöð, F2}

Fyrirtækið er við fjarðarb otn í péttbýli innan um ýmiss konar iðnrekstur (Mynd 41; Mynd 42). Fiskeldisstöð er rekin utar í firðinum.

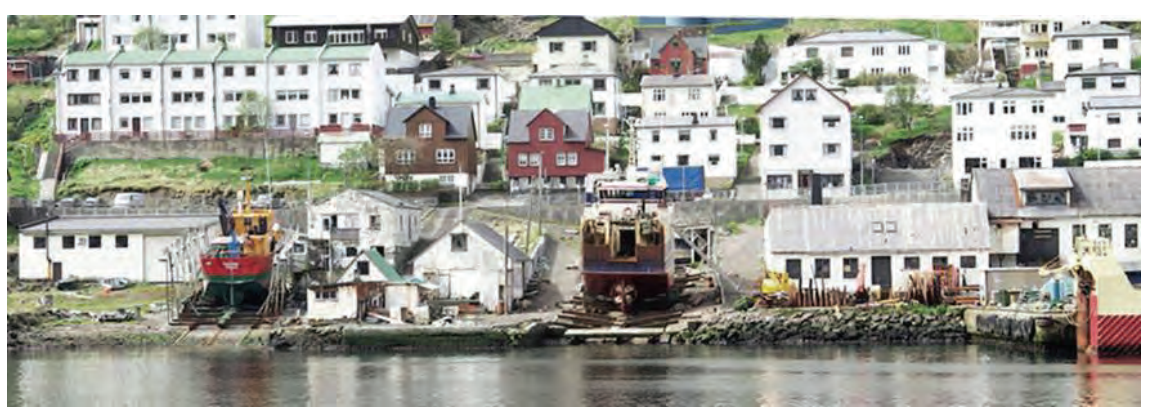

Mynd 41. Slippstöð F2 er við hliðina á minni slippstöð (til vinstri).

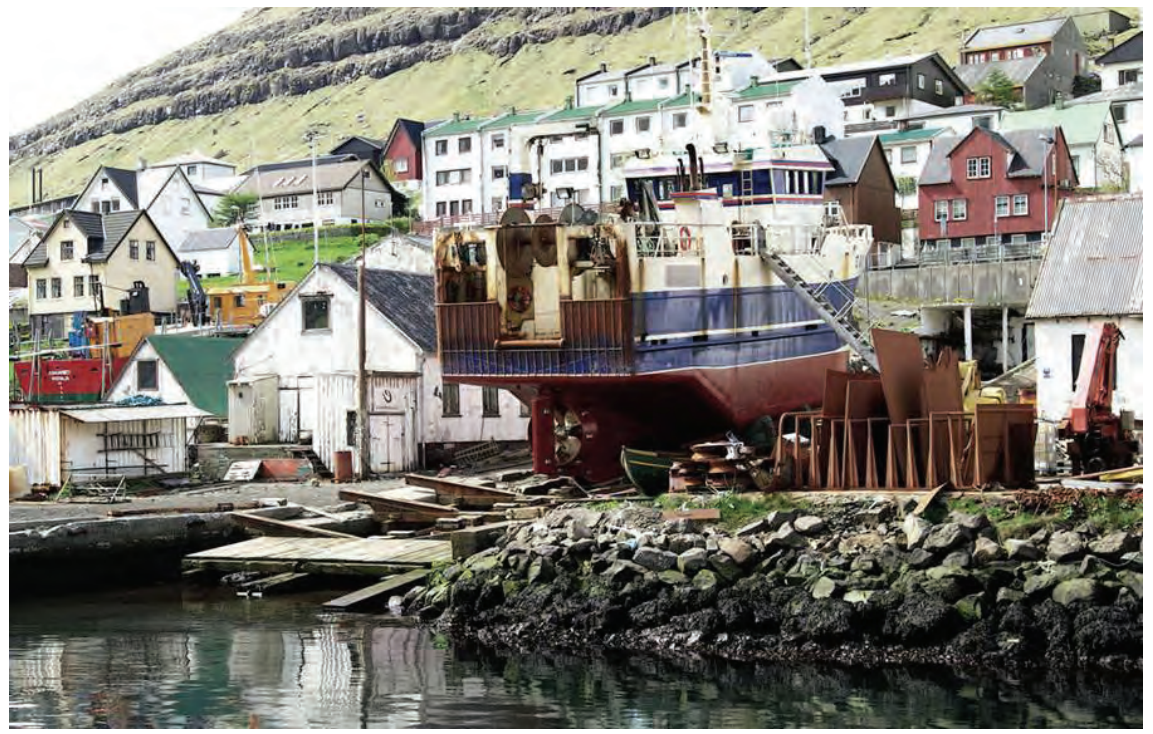

Mynd 42. Slippstöðin er i péttbýli eins og aðrar slippstöðvar sem við heimsóttum.

Á slippstöðinni starfa u m 20 manns, og par eru teknir allt að 15 plastbátar af stærðinni 20-35 fet á ári hverju, og um 15-20 stærri stálskip (35-80 fet).

Fyrirtækið an nast aðallega vélaviðhald, en í tengslum við pað er oft um að ræða málningar- og botnvarnar vinnu. Í slippnum er stór grind á teinum á heilsteyptri sementbraut (Mynd 43). 


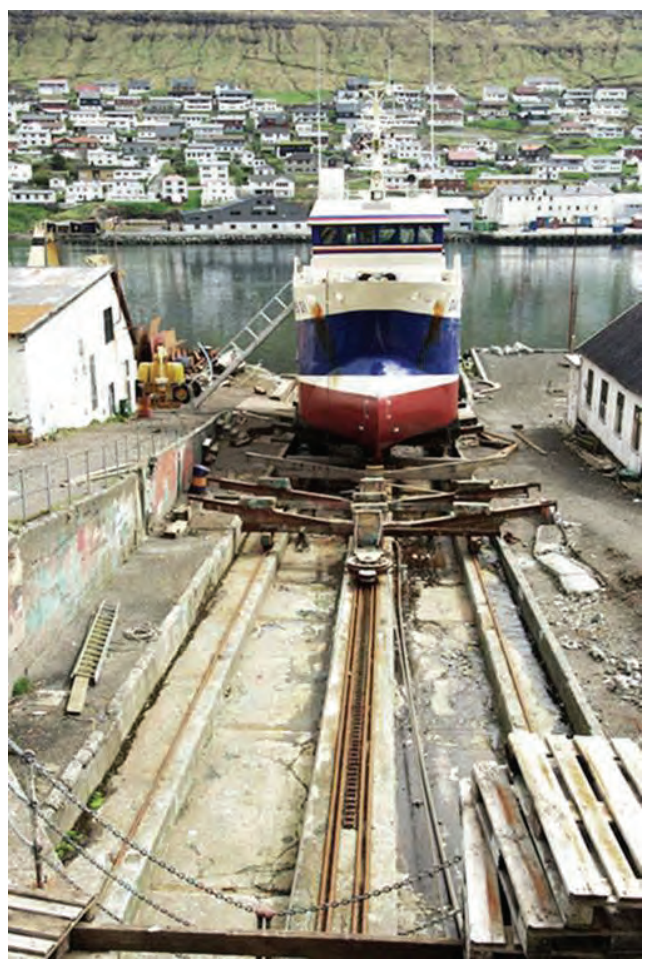

Mynd 43. Grind á teinum á heilsteyptri braut (sement)

Við botnhreinsun er aðeins beitt háprýstipvotti m eð vatni og ryðleysandi efnum, og síðan er borin á gróðurhi ndrandi bot nvörn. Gróður hindrandi málningin er af merkinu Hem pel og key pt hjá innflytjandanum í bórshöfn. Giskað er á að notaðir séu að meðaltali um 50 lítrar af botnvörn á hvern bát og nem ur ársnotkunin pví um 1400 lítrum. Hvorki frárennsli, málningarleifum né öðrum úrgangi var safnað saman. Fyrirtækið var með búnað til að flokka eigin úrgang, en töluverður úrgangur (plast, timbur og málmar) lá á víð og dreif á lóðinni. Úrgangsolíu var safnað saman og hún sótt af fy rirtæki á staðnum. Eigandinn vissi ekki hv að síðan varð um úrganginn né hvernig hann var meðhöndlaður.

Fulltrúi f yrirtækisins pekkti vel regl ur um losun og m eðhöndlun hættulegra efna og hafði h aldgóða pekkingu á ströng um reglum annarra landa um starfshætti. Hann vissi lítið um hvaða efni er bannað að nota og taldi að einhver eiturefni væru los uð ú tí um hverfið. Hann óskaði eftir betri eftirfylgni og aðgerðum af hálfu umhverfisstjórnvalda svo hægt væri að bæta ástandið hjá $\mathrm{f}$ yrirtækjum. Ef ekki kæm i til slíkra aðgerða, með fræðslu, ráðgjöf og fyrirmælum efaðist hann um að slippstöðvarnar tækju sjálfar upp um hverfisvænni hætti. Ha nn benti á að erlend ski p væru skyldug til að afhenda flokkaðan úrgang (gegn kvittun) pegar pau kæmu í slipp en minna væri fylgst með pví hvað yrði um úrganginn.

Fyrirtækið hafði ekki fengið nein fyrirmæli um að breyta starfsháttum. Menn höfðu hvorki ráðgert né gripið til úrræða til að minnka losun hættulegra eða ópekktra efna. 
Sjálfum fannst honum afar æskilegt að hafa hreint og sny rtilegt á vinnustaðnum án pess pó að sú hugsun hafi slegið í gegn hjá fyrirtækinu.

Fjaran fyrir neðan slippinn bar merki um iðnrekstur á staðnum (Mynd 44).

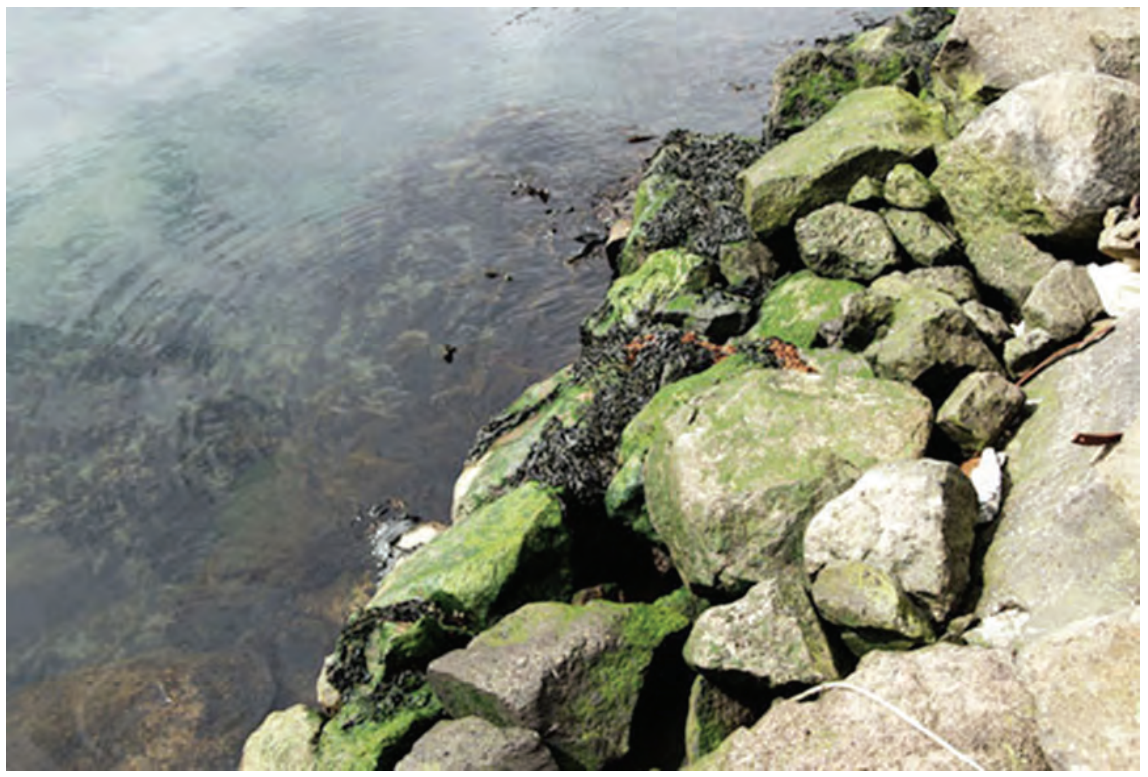

Mynd 44. Í flaððarmáli eru greinileg merk i um iðnrekstur á staðnum; grcen pörungur, gruggugt vatn og úrgangur.

\subsubsection{Fareysk slippstöð, F3}

Slippstöðin stendur í fjarðarbotni í pé ttbýli in nan um ý mis konar iðnrekstur. Fiskeldisstöð er utar með firðinum, en í fjarðarbotni er dýptin um 9 metrar á u.p.b. 1 km svæði.

Um 15 manns starfa í slippnum og annast aðallega stálbáta. Um 25-30 peirra eru stærri en 50 fet, en u.p. b. 5 eru minni. Fyrirtækið annast aðallega vélaviðhald en einnig málningarvinnu og botnvörn.

Í slippnum er stór grind á teinu má heilstey ptu pla ni (Mynd 4 5) og önnur á teinum á ósteyptu plani (Mynd 46). 


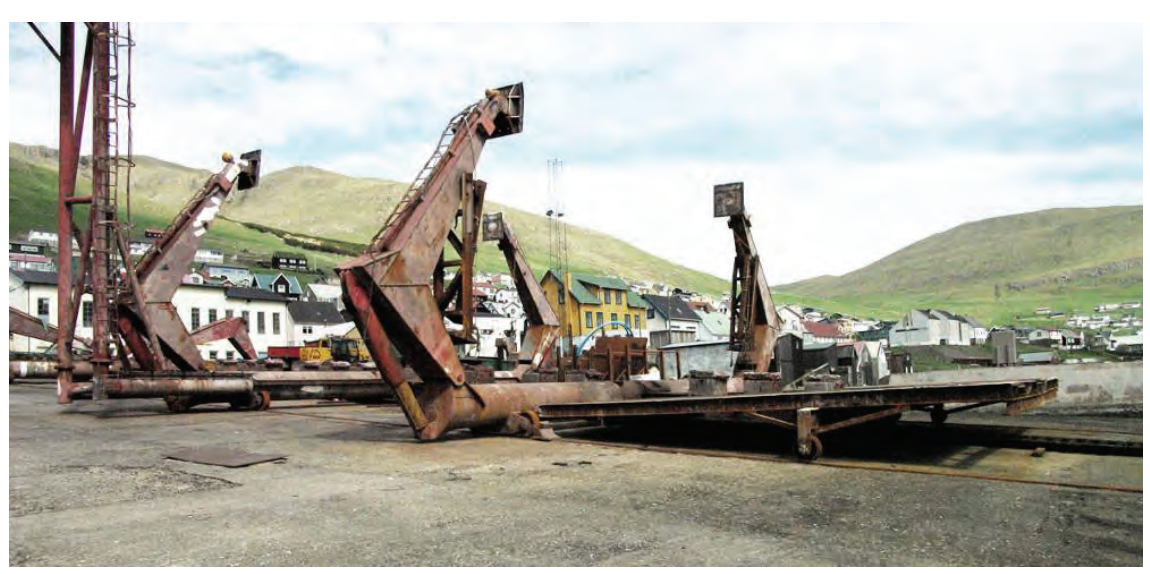

Mynd 45. Grind á teinum á heilsteyptu plani á slippstöð F3.

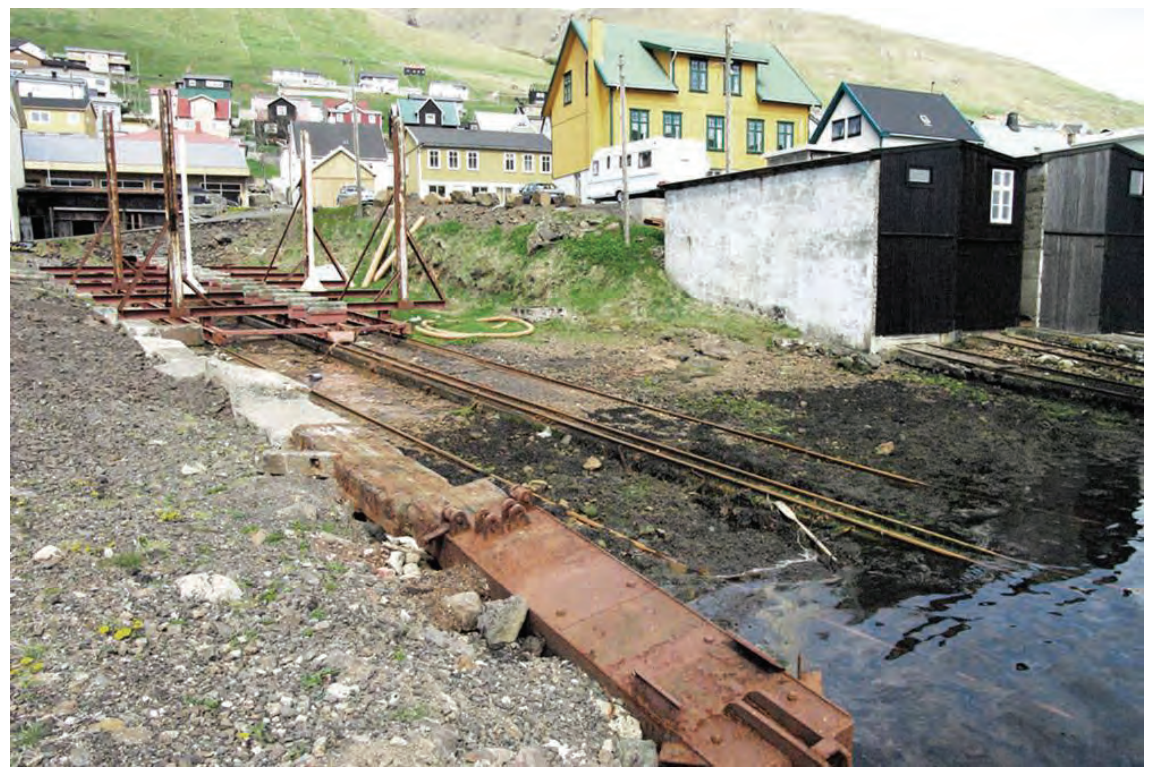

Mynd 46. Grind á teinum á ósteyptum jarðvegi á slippstöð F3.

Við hreinsun á botni er aðeins beitt háprýstipvotti með vatni, ryðle ysiefninu Kem ilux og gró ðurhindrandi m álningu. Viðskiptavin urinn velur sjálfur málninguna og er hún yfirleitt af merkinu Hempel, Sigma eð a International (Mynd 47). Að meðaltali fara u m 40 lítrar af málningu á botn hvers báts, samtals um 1400 lítrar á ári. 


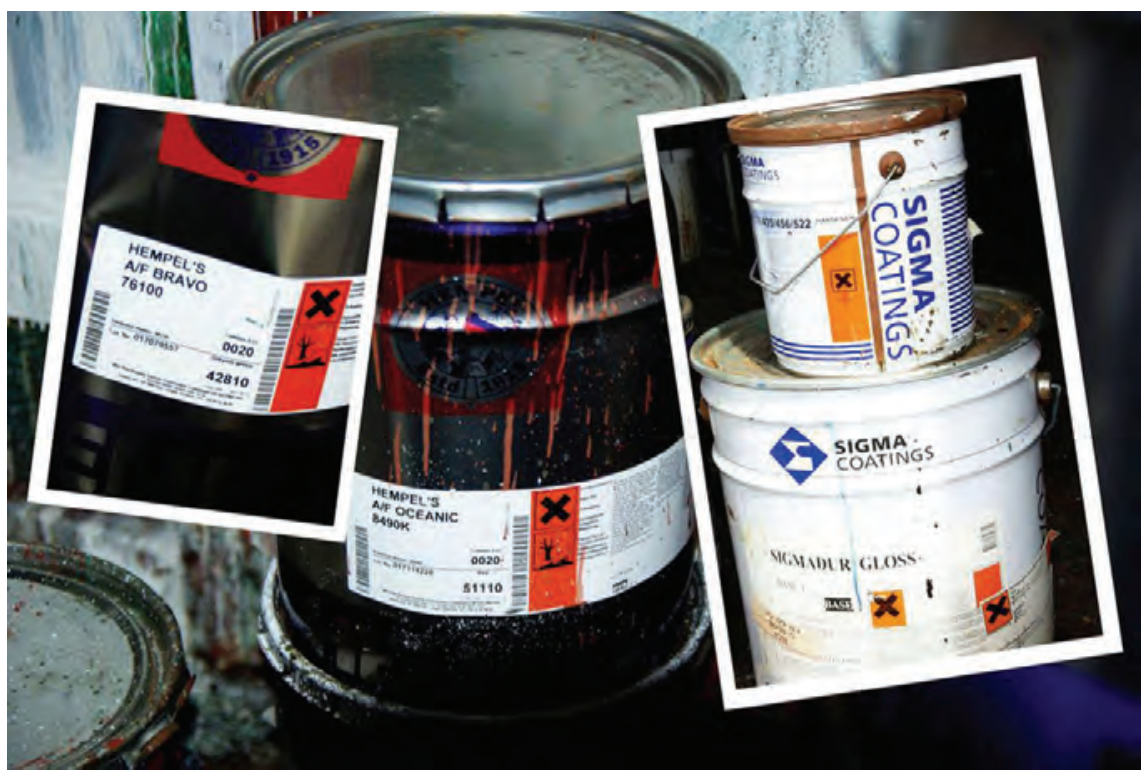

Mynd 47. Nokkrar efnavörur sem notaðar eru á slippstöð F3.

Fulltrúi fyrirtækisins hafði ekki kynnt s ér reglur um losun efna eða úrgangs út í umhverfið við m eðhöndlun báta, og viss i lítið um hvaða efni var bannað að nota. Hann taldi að fyrirtækið losaði umhverfisskaðleg efni út í náttúr una en vissi hv orki h ver pau voru né h vaða skaða bau gátu valdið. Fyrirtækið hafði ekki fengið fyrirmæli frá umhverfisstjórnvöldum og fannst skorta samrád við pau.

Fyrirtækið var að un dirbúa aðstöðu f yrir söfnun á f östum efnum frá planinu. Ráðgert var að setja fly tjanlegt pil til að loka af neðri kant plansins (Mynd 48), par sem hægt væri að safna saman úrgangi o g flytja á móttökustöð. Pá v oru áform um að heilstey pa plan fyrir neðan minnsta undirlagið. 


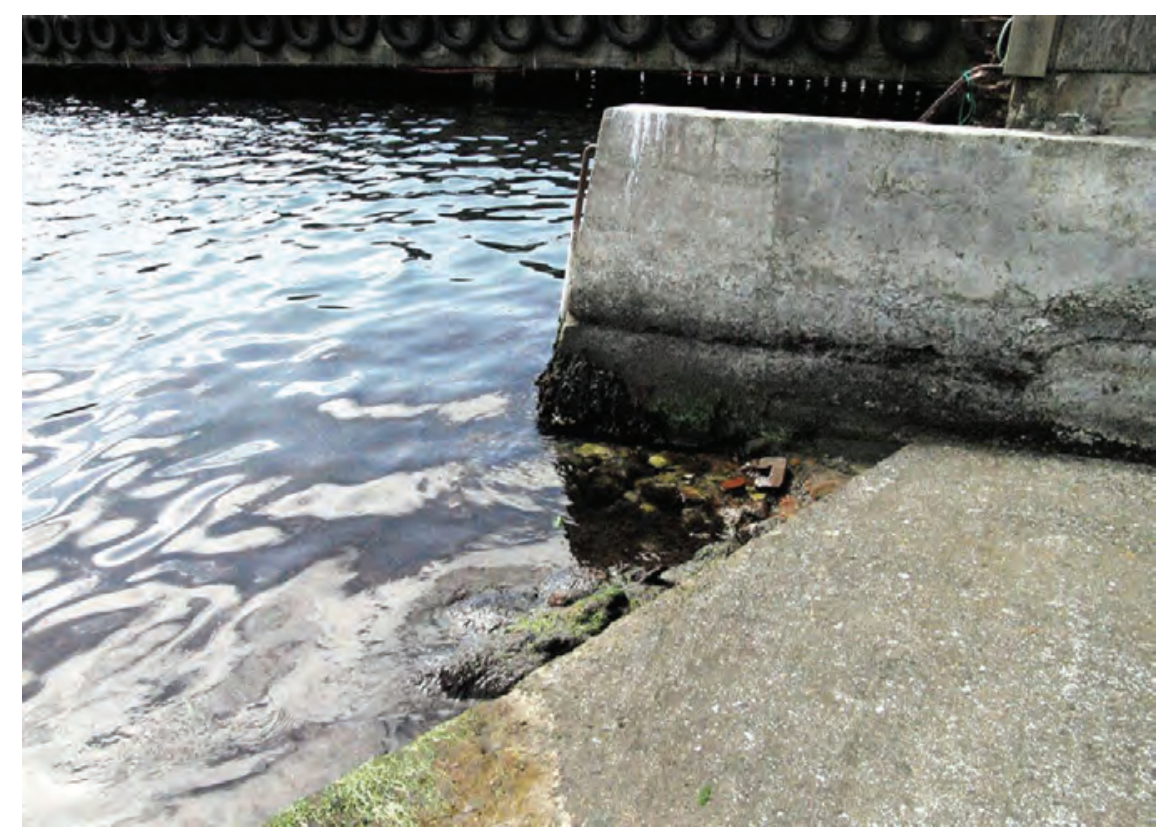

Mynd 48. Neðri kantur undirlagsins á slippstöð F3 par sem ráðgert er að setja pverslá.

Allir afgangsmálmar eru flokkaðir og seldir í br otajárn. Úrgangsolíu e r safnað í gey mi og hann afhentur til IR F (m óttökustöð sveitarfélagsins) (Mynd 49). IRF sækir olíuúrgang og flytur hann í sérstöku m geymi. Ókeypis er að afhenda olíuúrgang, par sem úrvinnslugjald hefur pegar verið greitt af olíuvörum sem notaðar eru.

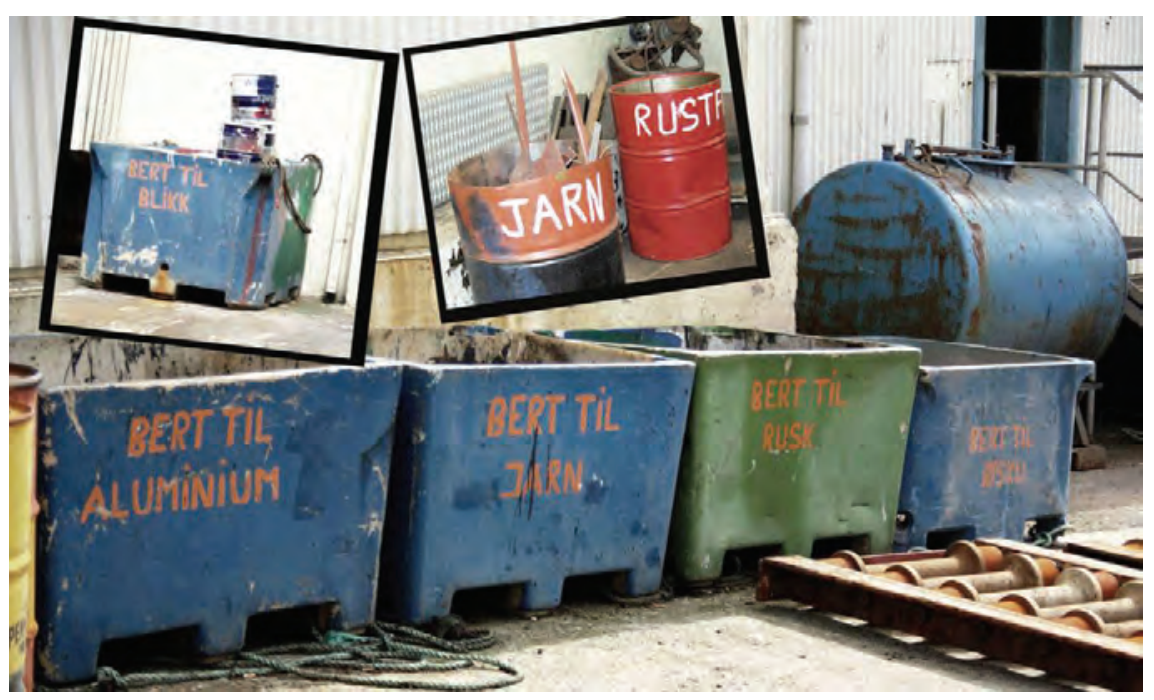

Mynd 49. Gámar fyrir flokkaða málma og geymir fyrir oliuúrgang.

Fulltrúi fyrirtækisins virtist hafa „heilbrigðar“ skoðanir á sny rtimennsku og um hverfismálum. Sumt var sýnt í verki; vinnustaðurin $n$ virtist snyrtilegur og fljótt á liti ð bar náttúra n í næsta ná grenni ekki merki um sýnilegan úrgang. 



\section{Samantekt, litlar slippstöðvar á Norðurlöndum}

\subsection{Samantekt, litlar slippstöðvar á Norðurlöndum}

Að einni undantekinni voru slippstöðvarn ar staðsettar par sem endurnýjun vatns var gó ð, og ekki var hæg tað ko ma aug a á áhrif staðbun dinnar mengunar á lífríkið.

pekking ei genda slippstö ðva á hættule gum efnu m var af skorn um skammti. Peir treysta pví að framleiðendur og söluaðilar efna selji aðeins vörur sem innihalda ley fileg efni. Menn vissu lítið um áhrif mengunar á umhverfið prátt fy rir að $\mathrm{p}$ eir gerðu sér grein $\mathrm{f}$ yrir $\mathrm{p}$ ví að sum efni sem peir vinna með geta verið skaðleg. Peir vissu lítið um afdrif og meðhöndlun úrgangs eftir að hann hafði verið fjarlægður og á einum stað lá mikill úrgangur á víð og dreif á lóð slippstöðvarinnar.

Fyrirtækin st óðu vel að merkingum á gám um og flokku n á úr gangi með einni undantekningu.

Ein slippstöð (m eð frárennsli út í aflokaða höfn) var að hluta til með hentugt pvottaplan en eftirlit með og tæm ing á úrgangsskál var ekki til fyrirmyndar. Hinar slippstöðvarnar höfðu hvorki áformað né gert ráðstafanir til að safna úrgangi eftir hreinsun á bátum.

Tvær voru í miðju péttbýli og pjónustuðu aðallega heimamenn. Ein lá afskekkt og önnur var í iðnaðarhverfi í péttbýli. Pví miður gafst ekki tími til að gera „nágrannakönnun“, p.e. að inna nágranna slippstöðvanna álits á peirri starfsemi sem par fór fram.

\subsection{Samantekt, litlar slippstöðvar á Álandseyjum}

Hafsvæðið umhverfis Álandsey jar er mjög viðkvæmt (ísalt, léleg endu rnýjun vatns, mikið af umhverfisskaðlegum efnu m), mið að við hafið meðfram No regs ströndum og um hverfis Færey jar. •að getu r skýrt hvers vegna betur er fylgst með starfsemi hér sem tengist bátum og bátaviðhaldi.

pekking eige nda slippstöðva á hættulegum efnum og áhrifum peirra var af skornum skammti en peir voru betur að sér um gildandi reglur. Pví vissu peir lítið um afleiðingar fyrir umhverfið prátt fyrir að peir gerðu sér grein fyrir pví að efni sem unnið var með gætu verið skaðleg.

Aðeins ein peirra priggja slippstöðva sem heimsóttar voru hafði búnað til að safna úrgangi og virtist hann virka mjög vel. Fyrirtækið hafði áform um að koma upp aðstöðu til að botnhreinsa báta í sjó. 
Hvergi voru áform um að koma upp pvottaplani par sem hægt væri að safna úrgangi.

Mikið bil var á milli „,bestu“ og „,verstu“ slippstöðvarinnar sem bendir prátt fy rir allt til pess að eftirlit með starfseminni sé lítið. Önnur stóra slippstöðin var nútímavædd og par va $r$ horft til framtíðar. Aðstaðan var tiltölulega um hverfisvæn, en hinar st öðvarnar virt ust hvorki kosta til búnaðar, bygginga né annarra úrræða til að vernda umhverfið.

Ein slippstöð var í miðju péttbýli við hliðina á tjaldsvæði. Hinar lágu pokkalega afsíðis frá annarri by ggð. Pví miður gafst ekki tími til að gera „nágrannakönnun“, p.e. að kanna viðhorf nágranna til starfseminnar.

\subsection{Samantekt, litlar slippstöðvar á Færeyjum}

Færeyjar eru umkringdar hafi á alla vegu og firðirnir gátu minnt á norskar aðstæður. Aðstæður og fámennið geta verið skýring in á pví að ekki er lögð eins mikil áhersla á lífríki hafsins og dæmin sýndu á Álandseyjum.

Á öllum slippstöðvum sem við heimsóttum gerðu menn sér grein fyrir pví að peir lo suðu efni sem geta veri ð skaðleg umhverfinu. Peir vissu pó lítið um hvaða efni pað væru eða hvaða skaða pau gætu valdið. Allir sýndu áhuga á nánara samstarfi við umhverfisstjórnvöld til pess að geta kynnt sér betur um hverfisstefnu og $\mathrm{k}$ omið á u mhverfisvænum starfsháttum. Einn eigandi virtist pekkja reglurnar vel.

Á öllum premur slippstöðvum var aðstaða til pess að safna úrgangi og virtist hún virka vel að einum stað undanskildum.

Hvergi var p vottaplan par sem hægt var að safna úr gangi en á einum stað var verið að undirbúa úrræði til að kom a í veg fy rir að frárennslið rynni beint út í sjó.

Allar slippstöðvarnar hafa verið st arfræktar á sama stað í mörg ár (lengur en 50 ár) og virðast pær vera eðlilegur og æs kilegur hluti af samfélaginu. Pó er ekki hægt að slá neinu föstu um petta pví takmarkaður tími gafst til að afla upplýsinga hjá nágrönnum slippstöðvanna.

Á einum stað voru óskir um vottunarkerfi til að koma í veg fyrir ævintýramennsku og umhverfisspillandi starfshætti í atvinnugreininni.

\subsection{Almennar athugasemdir}

\subsubsection{Rekstrarhoettir}

\section{Grindir á teinum.}

Hefðbundnar litlar slippst öðvar með drátta rbraut hafa y firleitt lítið pláss aflögu f yrir flokkunaraðstöðu o g ge ymslu á úrgangi. Sums staðar hafa teinarnir verið festir á steypt un dirlag (sement) en pað getur au ðveldað söfnun á föst um úrgangi eftir spúlun o g slípun. Annars staðar hafa tein- 
arnir verið lagðir á náttúr ulega fjöru, en pað torveldar söfnun úrgangs og kallar á kostnaðarsamar lausnir. Panni g rekstrarhættir tak marka fjölda báta í slipp á hverjum tíma en me ngunarhætta er í sam ræmi við fjölda báta sem meðhöndlaðir eru.

\section{Uppsátur með foranlegum einingum.}

Pað tíðkast æ meir að bátar séu teknir upp m eð færanlegum einingum, í stað hefðbundinnar aðferðar par sem bátar eru dregnir úr sjó á land. Eigi að takast að ná stjórn á mengun veg na viðhalds á bá tum er mikilvægt að upplýsingum um umhverfisvitund við meðhöndlun á bátum, hugsanlegu eftirliti og fyrir mælum um hverfisstjórnvalda sé einnig beint til pessara fyrirtækja. Mjög margir eigendur skemmtibáta undir 40 fetum skipta vi slippstöðvar sem bjóða up p á pjónustu, uppsátur og geymslu í smábátahöfnum. Bátunum er ýmist lyft á land með færanlegum krana, eða settir á grind á hjólu m sem dregin er af ly ftara. Síðan er peim ko mið fyrirá römpum á stóru svæði. Ekki parf marg a starfsmenn á hvern bát pví bátaeigendur sjá að mestu um verkið. Bátum sem lyft er úr vatn i er komið fyrir á stóru svæði, yfirleitt á ósteyptu plani sem er skipulagt eins og bílastæði. Rekstrarhættirnir fela í sér að bátaeigendurnir annast sjálfir flesta pvotta, málun og annað v iðhald. Dví e $r$ hætta á að eigendur slippstöðva hafi litla y firsýn y fir pað sem fram fer og að spillie fni úr bátum berist á stórt svæði. Oft er góður spölur y fir á bvottaplanið eða gáma sem eru merktir fyrir úrgang, ef peir eru pá til staðar.

Norsk skipulagsstjórnvöld setja engar skorður fyrir nýtingu svæða sem hafa leyfi til atvinnureksturs (annað en tímamörk) en gera ráð fyrir pví að menn virði almenn lög og reglur. Hug sanlega mætti láta sérstök skily rði fylgja notandaleyfunum.

Pegar bátar á landi taka ekki dýrmætt pláss eða búnað (t.d. gri nd á teinum), eru peir oft ski ldir eftir sem flök (úrgangur) og $\mathrm{v}$ alda pví umhverfisvanda. Hér mætti nýta sér rey nslu af meðhöndlun bílhræja par sem alltaf er hægt að kalla eiganda til áby rgðar fyrir að skilja pau eftir. •að krefst pess að allir bátar séu al mennilega skráðir og m erktir en búast má við að einhver tími líði par til pað getur gerst.

\subsubsection{Pekking}

Almennt má segja petta um öll svæðin prjú:

- Fyrirtækin vissu lítið um umhverfisskaðleg efni.

- Menn höfðu almennt áhuga á eins umhverfisvænum rekstrarháttum og unnt er, svo framarlega sem kostnaður riði peim ekki á slig. Sumir höfðu nokkurn veginn hugmynd um hvernig stuðla ætti að umhverfisvænum starfsháttum, en aðrir ekki.

- Næstum pví allir voru óöryggir á pví hvaða reglur væru í gildi. 
Allir viðmælendur okkar vissu lítið um hvaða efni væru skaðleg umhverfinu eða bönnuð í botnmálningu. Allir sögðust peir trey sta pví að söluaðilar/verslun/innflytjendur væru $n$ ægjanleg trygging $\mathrm{f}$ yrir pví a $\partial$ aðkeypt efni n væru lögle g. Pá v issu peir að slipp stöðvar hefð u valdi ð mengun en ekki hvort sú væri raunin í dag.

Ástæður fyrir vanpekkingu manna á reglum um losun og meðhöndlun á spilliefnum eru líklega annars vegar sú að fy rirtækin firra sig áby rgð á að k ynna sér reglurnar o g hins vegar að reglurnar eru mjög óaðgengilegar. Mörg fyrirtæki eru rekin á hefðbundinn hátt og telja allt með felldu par sem pau hafa ekki fengið fyrirmæli um annað. Peir gera sér ekki grein fyrir eða hafa ekki velt fyrir sér hvort fyrirtækinu beri skylda að kynna sér lög o g reglu gerðir og f ylgja peim. Við kom umst að pví að reg lur eru frekar óaðgengilegar brátt fy rir að margar peirra séu birtar á netinu. Ekki allir yfirmenn fyrirtækja notfæra sér rafræna pjónustu.

Að einu $m$ stað undanskil dum urðu $m$ við hvergi $v$ ör við haldg óða pekkingu á reglum $\mathrm{u}$ m notkun efna eða afhending u úrgangs fr á fy rirtækinu. Par sem vel var staðið að meðhöndlun úrgangs, virtist pað vera að pakka sny rtimennsku og áhuga á vinn uumhverfi og náttúrun ni í kring, öllu heldur en að f yrirtækin fylgdu reglum eða fy rirmælum stjór nvalda. Slippstöðvar í Noregi og Færeyjum óskuðu eftir be tri upp lýsingum og nánara samráði við um hverfisstjórnvöld. Aðeins ein slippstöð sem við heimsóttum (á Álandsey jum) virtist ve ra algjörlega úr takti v arðandi umhverfisvænan rekstur og viðhorf til umhverfisstjórnvalda.

\subsubsection{Viðhorf}

Víðast hvar urðum við greinilega vör við jákv æð viðhorf gagnvart umhverfisvænum rekstrarháttum og samr áði við stjórnvöl d. Sums staðar birtist pað greinilega í snyrtilegum vinnustöðum og góðum starfsvenjum, bæði í rekstr i og við söf nun úrgangs. Annars staðar virtist ver a lélegt samræmi á milli góðs ásetnings og framkvæmdar.

Á eingöngu einni slippstöð höfðu verið gerðar ráðstafanir til að koma í veg fyrir losun í sjó. Oft er erfitt og tiltölulega kostnaðarsamt að k oma á pannig búnaði. bví vill brenna við að menn ráðist ekki í verkið fy rr en peim hafa borist fy rirmæli frá stjórnvöldum, brátt fyrir fagrar y firlýsingar um að gera reksturinn umhverfisvænni. 


\section{6. Úrræði sem mælt er með}

\subsection{Umhverfisstjórnvöld}

Umhverfisstjórnvöld hafa fram að pessu f ylgst lítið með starfsemi lítilla slippstöðva. Margar peirra byggja á gamalli hefð og reksturinn he fur lítið breyst prátt fyrir að ný pekking og nýjar reglur hafi komið til. Ástæðan er líklega sú að fáir $\mathrm{f}$ yrirtækjaeigendur $\mathrm{g}$ era sér grein $\mathrm{f}$ yrir að peir bera sjálfir ábyrgð á að kynna sér lög og reglur. Í samráði við umhverfisstjórnvöld væri hæ gt að skýra áby rgð hvers og eins og gæti pað í mörgum tilvikum leitt til bættra rekstrarhátta. Ef eigendur fyrirtækja og mannvirkja, sem notuð eru und ir slipp og viðhald á bátum, gerðu sér betur grein $\mathrm{f}$ yrir ábyrgð sinni á mengun jarðvegs gæti pað leitt til pess að peir fy lgdust betur $\mathrm{m}$ eð starfsháttu $\mathrm{m}$ bátseigenda. Mengaður jarðvegur er á áby $\operatorname{rg} ð$ lóðareiganda og hreinsun hans getur hæglega orðið æri kostnaðarsöm.

Eigendur slippstöðva telja almennt að reglurnar séu óaðgengilegar. Pörf er á að útbúa einfalt og auðskiljanlegt fræðslu- og up plýsingaefni og dreifa pví til fy rirtækjanna. S em d æmi u m fræðsluefni má n efna b æklinginn „Báturinn - hrein án ægja“ sem Norr æna ráðherran efndin útbjó fyrir eigendur skemmtibáta [www.norden.org/da/publikationer/publikationer/2005 -749/]. Fyrst parf að semja fræðsluefni og síð an að dreifa pv í til markhópsins. Fræðsluefni fyrir eigendur slip pstöðva getur t.d. legið frammi par sem gróðurh indrandi málning og aðrar viðhaldsvörur eru til sölu. Umhverfisstjórnvöld geta einnig sent fræðsluefni eða selt til fyrirtækja.

Eftirlit um hverfisstjórnvalda gæti líklega stuðlað að bættum st arfsháttum á mörgum litlum slippstöðvum. Víða óskuðu menn eftir eftirliti af hálfu um hverfisstjórnvalda en su ms staðar var okku r tjáð að ekki y rði gripið til úrr æða fy rr en fy rirmæli b ærust par að lútandi. Víða y rðu „ódýrar" og síður um hverfisvænar lausnir fyrir valinu par sem eftirlit og viðurlög eru engin. betta gæti smitað út frá sér til nærliggjandi fyrirtækja.

\subsection{Litlar slippstöðvar}

\subsubsection{Smábátaslippstöðvar með dráttarbraut á teinum}

Pessar stöðvar taka lítið rými og eru með fáa báta í slippi í einu. Par mætti koma upp bú naði til að safna ú rgangi eftir spúlun, málun og olíuskipti. Sjálf dráttarbrautin, par sem t einarnir eru lagðir b eint á jörðin a, getur torveldað að slíkum söfnunarbúnaði sé komið upp. Pegar teinarnir eru á föstu undirlagi (stey pu eða malbiki) er auðv eldara að ko ma upp bún aði fy rir 
söfnun og hrein sun á frárennsli. Aðeins á einu m stað (slipp stöð F3) voru menn að íhuga að koma á slíkum búnaði (Mynd 48).

Í skýrslunni „Miljöanpassat båtuppt ag - Reningsanläggning f ör alla hamnstorlekar" (Samuelsson, 2006), eru kynntar mismunandi leiðir til að fanga og hreinsa fastan og fljótandi úrg ang og einnig kostnaðará ætlanir fyrir fjárfestingar og rekstur á slíkum búnaði. Á skýringarmynd er ferlinu skipt í skref 1 og 2 (Mynd 50). Fyrra skrefið felur í sér pétt plan sem hallar niður í rennu, par sem frárennslið safnast saman í miðjunni og er leitt niður í botnfallsskilvindu. Par sem mjög stór hluti af spilliefnum samanstendur af gróðurhindrandi efnum og botnmálningu ætti að innleiða skref 1 á öllum uppsátrum. Skref 2 felur í sér hreinsun á frárennsli með síum og dælum. Í ský rslunni er mælt með pví að innan ein s árs verði kom ið á búnaði til að geta tekið 250 báta á land á ári hverju en pó ráði umhverfisaðstæður um hvort pess gerist nauðsyn.

Í skýrslunni eru nákvæm ar teikningar af „Vallda Sandøs spolpl atta“ með botnfall sskilvindu og sandsíu (M ynd 50). Ráðg erður kostnaður eru u.p.b. $1000 \mathrm{SEK} / \mathrm{m}^{2}$ (2006) ef fyrirtæki er fengið til verksins. Í skýrslunni er einnig greint frá fjárhag slegum forsendum fy rir að reka slíkan búnað. Giskað er á að kostnaðuri nn við hreinsibúnaðinn sé á bilinu 57 til 336 sænskar krónur (200 6) á h vern bát, en pað fer eftir pví hv ort bæði skref ferlisins hafa verið tekin og eins ef tir pví hve margir bátar eru teknir í slipp á hverju ári. (Tafla 2)

Tafla 2. Áætlaður kostnaður á bát (sænskar krónur, 2006) til standa straum af kostnaði við búnað til að safna og meðhöndla frárennsli. (Samuelsson, 2006).

\begin{tabular}{rrr}
\hline Fjöldi báta/ár & Skref 1 & Skref 2 \\
\hline 250 & 57 & 125 \\
120 & 60 & 176 \\
50 & 94 & 188 \\
15 & 156 & 336 \\
\hline
\end{tabular}

Grunnfjárfestingar í slíkum búnaði er u pað m iklar að fáar litlar slippstöðvar geta ráðist í slíkar framkvæmdir af eigin rammleik. 


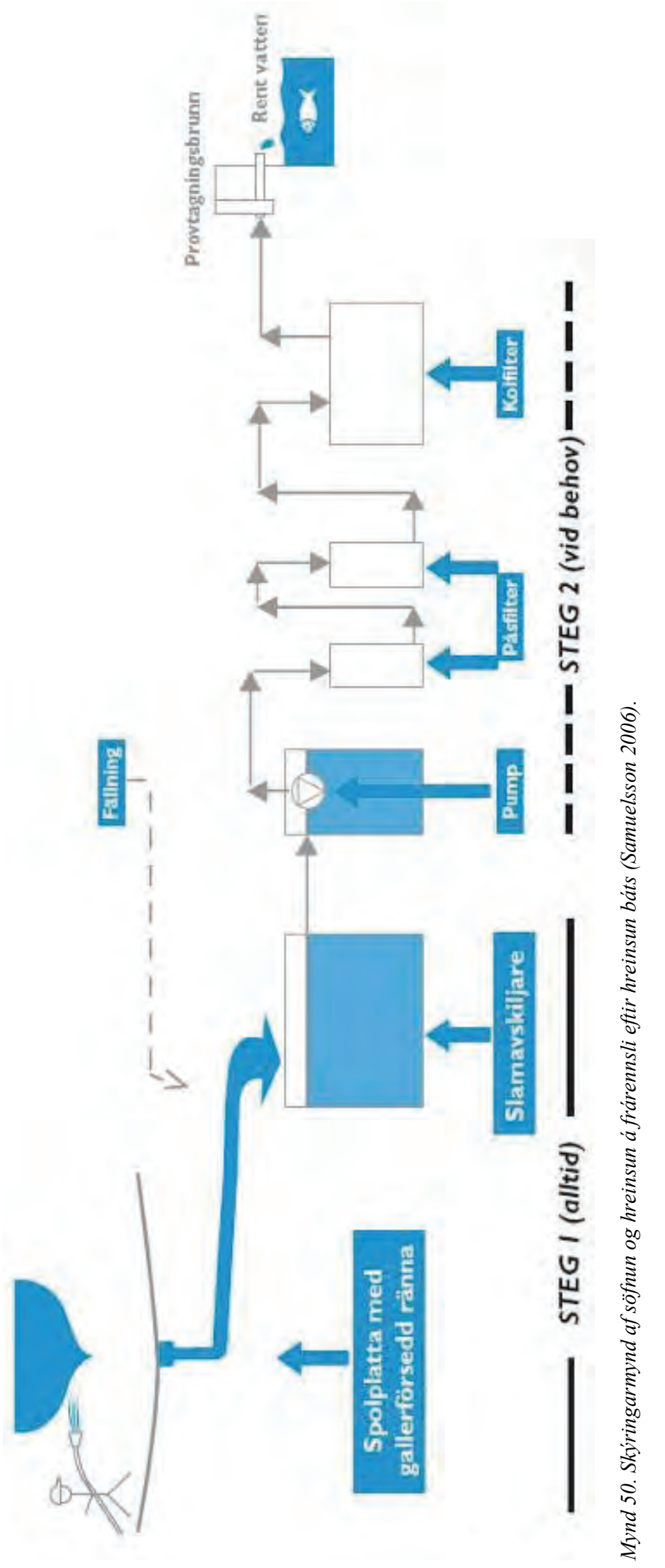




\subsubsection{Uppsátur með foeranlegum einingum.}

Nær öllum skemmtibátum er lyft með færanlegum krönum á skipu lögðum slippstöðvum. Marg ir bátar fara h ér um á hverju ári og bví purfa hugsan legar aðgerðir að miðast við slík an r ekstur. Aðg erðir fy rir fy rirtæki se m pjónusta marga báta í einu geta t.d. verið:

- Fyrirmæli um að allir bátar séu spúlaðir á pvottaplani með viðurkenndum söfnunarbúnaði fyrir leifar eftir spúlun/botnmálun (sjá Mynd 50).

- Auðskiljanlegu fræðsluefni verði dreift til allra bátaeigenda sem nýta sér pjónustu eða aðstöðu slippstöðvarinnar.

- Sköpuð verði aðstaða til að hreinsa báta í sjó sem valkostur við botnmálun á bátum (sjá síðar).

- Skilgreina ábyrgð bátaeigenda og eigenda fyrirtækja á úrgangi frá bátum.

- Skapa aðstöðu fyrir flokkun á úrgangi. Merkingar purfa að vera góðar eigi pær að pjóna tilgangi sínum.

\subsubsection{Allir}

Önnur úrræði sem getið er í mörgum skýrslu m u m u mhverfismál í tengslum við báta er bátapvottur pa r sem báturinn liggur í sjó, nokk urs konar sjálfsafgreiðsla með burstum sem snúast líkt og á bíla pvottastöðum. Pannig bú naður gæti leyst botnvörn með gróðurhindrandi efnum af hólm i, pví botnin $\mathrm{n}$ yrơi pvegin $\mathrm{n} n$ okkrum sinnum á hverri vertíð. Áhrifin og verðið á hverjum pvotti myndi skipta s köpum u m pað hvort petta félli í góðan jarðveg hjá viðskiptavinum. Í sæn ska dagblaðinu „Dagens Ny heter“ (1. febrúar 2008) stóð eftirfarandi: „, Nú síðast leiddi könnun í ljós að $81 \%$ bátaeigenda sem prófað hafa bátapvott munu halda pví áfram og að $48 \%$ peir ra sem pvo bá ta sína eru alveg hættir að nota gróðurhindrandi botnm álningu." Britta Eklund, sem stundar rannsóknir við um hverfisvísindastofnun Háskólans í Stok khólmi, hefur eftirf arandi að segja u m petta: „Árangurinn er gó ður pegar á heildina er litið. Sum ir kvarta undan pví að óhr einindin náis t ekki alveg burt - aðallega í

skutnum. En skýringin kann að vera sú að bátarnir séu pvegnir of sjaldan, að meðaltali 1,3 si nnum á hverri ve rtíð, en við mælum með pví að bátarnir séu pvegnir prisvar sinnum á sama tíma.“

Sums staðar er aðstaða fyrir slíkan bátapvott en enn er verið að útfæra pá hugm ynd nánar. Búna ðurinn hefur t.d. verið te kinn í not kun f yrir ferjur se m si gla u m Ál andseyjar. Pó eru ým is tæk nileg atriði óley st í samanburði við pvotta á landi o g kannski purfa stjór nvöld að sýn a meiri áhuga og veita aðstoð til pess að skriður komist á pessi mál. 


\section{Niðurstöður}

- Víða sýndu menn áhuga á að gera reksturinn umhverfisvænni svo framarlega sem kostnaðurinn riði fyrirtækinu ekki á slig.

- Lög og reglur eru óaðgengileg (leynast í mörgum og mismunandi EBgerðum og innlendum reglugerðum).

- Starfsmenn fyrirtækja vissu lítið um hvaða lögum og reglum fyrirtækið ætti að fylgja. Almennt virtust menn vænta pess að pekkingin bærist peim sjálfkrafa (líklega frá umhverfisstjórnvöldum á staðnum). Enginn hafði borið sig sjálfur eftir nýrri pekkingu.

- Könnun á rekstri lítilla slippstöðva á premur svæðum (Tromsfylki, Álandseyjum, Færeyjum) leiddi í ljós að ástandið var um margt svipað á pessum stöðum.

- Við sáum dæmi um góða rekstrarhætti slippstöðva fyrir smábáta og annað sem mætti betur fara. Hvergi var búnaður til að fylgjast með eða hreinsa frárennsli og úrgang eftir hreinsun og skröpun á bátum á landi, prátt fyrir að á einum stað hafi verið búið að koma upp skál fyrir fastan úrgang eftir spúlun.

- Hvergi var aðstaða til að botnhreinsa báta í sjó.

- Meðhöndlun, p.e. flokkun og afhending á spilliefnum var mjög mismunandi, allt frá algjöru skeytingarleysi til prýðilegra starfsvenja.

- Pá er ástæða til að fylgjast með pjónustuhöfnum, par sem ekki eru reknar hefðbundnar slippstöðvar (dráttarbraut á teinum) heldur færanlegur lyftibúnaður til að lyfta bátum og leggja peim hvar sem á lóðinni.

- Umhverfisstjórnvöld ættu að hefja samráð og upplýsingaskipti við eigendur/yfirmenn slippstöðva.

- Umhverfisstjórnvöld geta lagt sitt af mörkum með pví að semja og dreifa fræðslu- og upplýsingaefni um lög, reglur og úrræði til að bæta rekstrarhætti á slippstöðvum.

- Nauðsynlegt er að koma á eftirliti til að bæta umhverfisvæna rekstrarhætti hjá smábátaslippum.

- Yfirmenn slippstöðva sem annast viðhald á bátum purfa sjálfir að kynna sér lög og reglur, og eins hvaða úrræða er pörf til að gera starfshætti og búnað umhverfisvænni.

- Litlar slippstöðvar geta einfaldlega komið upp aðstöðu til að flokka og meðhöndla spilliefni. Hvar sem við komum voru aðstæður fyrir hendi til að koma upp búnaði fyrir söfnun á úrgangi.

- Skapa parf einfalda aðstöðu á öllum litlum slippstöðvum til að safna föstum efnum úr frárennsli. Slippstöðvar par sem margir bátar fara um á ári hverju purfa einnig að koma upp hreinsibúnaði fyrir frárennsli. 



\section{Heimildir}

Báturinn, hrein ánægja. 2005. Upplýsingar til bátseigenda á Norðurlöndum. Vefslóð: [www.norden.org/en/publications/publicati ons/2005-749/at_download/publicationfile]. SFT, 2005. Kartlegging av skipsverft. Steder hvor det kan ha oppstått forurensningsproblemer knyttet til bygging, vedlikehold og reparasjon av skip og offshoreinstallasjoner TA-2044/2004 ISBN 82-7655-233-1

SFT, 2004. Forurensningssituasjonen i småbåthavner. Status, økologisk risiko, spredningsvurdering og tiltaksbehov (TA-2071/2004)

Per-Olof Samuelsson, Stenungsunds kommun, 2006. Miljöanpassat båtupptag - Reningsanläggning för alla hamnstorlekar. Verkefnisskýrsla, apríl 2006

Kemikalieinspeksjonen 2004. Kemiska ämnen i båtbottenfärger - en undersökning av koppar, zink och Irgarol
1051 runt Bullandö marina 2004. Rapport $\mathrm{Nr}$ 2/06. Vefslóð: [www.kemi.se]

HELCOM, 2004. The Fourth Baltic Sea Pollution Load Compilation (PLC-4). Balt. Sea Environ. Proc. No. 93 HELCOM 2008. [www.HELCOM.fi] Mørch, T. 2005. Harstad havn Miljøundersøkelser og risikovurdering av forurensede sedimenter og tiltaksutredning. Sweco Grøner rapport nr. 128440-1.

Evenset, A. \& R. Palerud 2004. Miljøgifter i sediment fra Skattøra marina, september 2004. Akvaplan-niva rapport 414.3173.

Evenset, A., L.-H. Larsen, A. Kibsgaard \& A. Pettersen 2005. Forebygging og sanering av miljøgiftforurensning $\mathrm{i}$ Tromsø havneområde og Tromsøysund. Akvaplan-niva rapport 421.2508.03. SFT rapport TA 2084/2005. 68 p + appendix. 



\section{Fylgiskjal 1 - Bréf og spurningalisti}

Scel

Ég vísa til símtals okkar rétt fyrir páska um starfshætti og umhverfismál á litlum slippstöðvum.

Hér fy lgja nánari upplýsi ngar og drög að spurningalista til pess að gefa mynd af pví hvaða upplýsingum ég er á hö ttunum eftir pegar ég heimsæki slippstöðina. Ég vonast til að heimsækja ykkur í fyrsta lagi í lok viku 14 eða síðar. Ég slæ á práðinn í næstu viku.

\section{Litlar slippstöðvar á Norðurlöndum, upplýsingaverkefni um starfsemi lítilla bátaslippa}

Starfsmaður Akvaplan-niv a óskar eftir að heim sækja fy rirtækið eina dagsstund á tímabilinu apríl-júní 2008 til pess að miðla faglegri pekkingu á u mhverfismálum og kynna sér hvernig f yrirtækið ley sir umhverfismál við viðhald á bátum.

\footnotetext{
Akvaplan-niva er sjálfstætt ráðgjafafyrirtæki á sviði fiskeldis og sjávar- og vatn alíffræði. Hjá f yrirtækinu starfa 60 líffræ ðingar, vistfræðingar, efnafræðingar og jarðfræðingar víðs vegar að úr heiminum. Efnafræði- og líffræ ðirannsóknastofur okkar eru alpjóðlega v iðurkenndar og eru par gerð ar h ágæðagreiningar. Aðalskrifstofa og rannsóknastofur Akvaplan-niva eru til húsa í Polarm iljøsenteret í Tromsö í Noregi.
}

\section{Aðdragandi}

Faghópur $\mathrm{u} \mathrm{m}$ dreifðar byggðir sem starfar á $\mathrm{v}$ egum norræn a ú rgangshópsins (NAG), sem er starfshópu $r$ undir embættismannan efndinni um umhverfismál (EKM) á vegu m Norrænu ráðherranefndarinnar, fó 1 Akvaplan-niva að kann a starfsemi á litlum slippstöðvum á No rðurlöndum út frá umhverfiskröfum hins opinbera til pess að stemma stigu við mengun á u mhverfinu. Norræn a ráðherran efndin fjármagn ar könnunina en hún fer fram á litlum slippstöðvum á Álandseyjum, í Noregi og Færeyjum.

Með „, umhverfiskröfum hins opinbera“ er átt við kröfur sem koma fram í alpjóðlegum, innlendum og staðbundnum reglum.

Pað á einkum við u m notkun á botnv örn á skip með gróðurhindrandi efnum, par sem sum pessara efna geta haft skaðleg áhrif á dýr og menn ef ekki er rétt með pau farið.

Hver erum við og hvað getum við lagt af mörkum:

Fyrirtæki okkar býr yfir sérpekkingu í umhverfismálum, og við munum leitast við að aðstoða með upplýsingum um meginreglur, aðferðir og efni 
sem henta til að hindra gróðurvöxt á bátnum , og hvernig kom ast má hjá eða takmarka skaðleg áhrif á umhverfið.

Mikilvægur páttur verkefnisins fels tí að heimsækja fy rirtæki og nágrenni peirra á tímabilinu apríl-júní. P annig getum við k ynnt ok kur af eigin raun hvort $\mathrm{p}$ örf sé á bættu m upplýsing um $\mathrm{u}$ m notkun o $\mathrm{g}$ meðhöndlun hættulegra og ópekktra efna . Við ósku m eftir að kortleggja góða starfshætti sem gætu aukið öryggi í nánasta um hverfi fyrirtækisins. Við gerum ráð fyrir að verja einum vinnudegi í að kortleggja slippstöðina og nágrenni hennar og vonum að pið s jáið ykkur fært að verja no kkrum klukkustundum með okkur.

\section{Markmið}

Umhverfisstjórnvöld m unu nýta nið urstöður kö nnunarinnar við gerð á norrænu fræðslu- og up plýsingaefni fy rir slip pstöðvar og bátaeigendur. Markmið með upplýsingunum er m.a. að:

- tryggja umhverfisvæna starfshætti á litlum slippstöðvum og hlífa pannig bæði dýrum og heilbrigði manna

- fræða slippstöðvar og bátaeigendur um umhverfismál varðandi viðhald og notkun báta

- tryggja að starfsmenn slippstöðva og bátaeigendur pekki staðbundnar, innlendar og alpjóðlegar reglur og pekki ábyrgð sína í peim efnum.

Ef óskað er eftir nánari upplýsingum er velkom ið að senda okkur fy rirspurnir.

Með bréfinu fylgir spurningalisti en par kemur fram hvað vonast er til að fá svar við í heimsókninni.

Kveðja,

Fyrir hönd Akvaplan-niva AS 


\section{Sniðmót fyrir vettvangskönnun}

\section{Skrá yfir tæknilegar útfæringar á slipp}

\begin{tabular}{|c|c|c|c|c|c|}
\hline \multicolumn{6}{|l|}{ Lyftibúnaður/fjöldi } \\
\hline \multicolumn{6}{|l|}{ Grind á teinum } \\
\hline \multicolumn{6}{|l|}{ Grind á hjólum } \\
\hline \multicolumn{6}{|c|}{ Bryggjukrani } \\
\hline \multicolumn{6}{|c|}{ Bryggjukrani á hjólum } \\
\hline \multicolumn{6}{|c|}{ Annað (purrkví, pvottur á bryggju ...) } \\
\hline \multicolumn{6}{|c|}{ Umfang reksturs } \\
\hline \multirow[t]{2}{*}{ Bátastærð (m/f) } & \multirow{2}{*}{$\begin{array}{l}\text { Bátafjöldi á } \\
\text { vertío }\end{array}$} & \multirow{2}{*}{$\begin{array}{l}\text { Meðhöndlu } \\
\mathrm{n} \text { botna-m }\end{array}$} & \multicolumn{3}{|c|}{ Hlutfall verka af starfsemi í \% } \\
\hline & & & Spúlun & $\begin{array}{l}\text { Spúlun og } \\
\text { botnmálun }\end{array}$ & $\begin{array}{l}\text { Spúlun, skröpun } \\
\text { og botnmálun }\end{array}$ \\
\hline \multicolumn{6}{|l|}{$<6 / 20$} \\
\hline \multicolumn{6}{|l|}{$6-10 / 20-33$} \\
\hline \multicolumn{6}{|l|}{$10-15 / 33-50$} \\
\hline \multicolumn{6}{|l|}{$15-25 / 50-83$} \\
\hline \multicolumn{6}{|c|}{ Yfirlit yfir efnanotkun } \\
\hline \multicolumn{2}{|c|}{ Nöfn, 3 algengustu: } & merki & Hlutverk & $\begin{array}{l}\text { Hlutfallsleg } \\
\text { notkun (\%) }\end{array}$ & Áætluð ársnotkun \\
\hline \multicolumn{6}{|l|}{ Pvottaefni } \\
\hline \multicolumn{6}{|l|}{ Botnvörn } \\
\hline \multicolumn{6}{|c|}{ Botnvörn } \\
\hline Önnur efnasamb & önd & & & & \\
\hline
\end{tabular}

\section{Yfirlit yfir starfshætti:}

Starfsvenjur

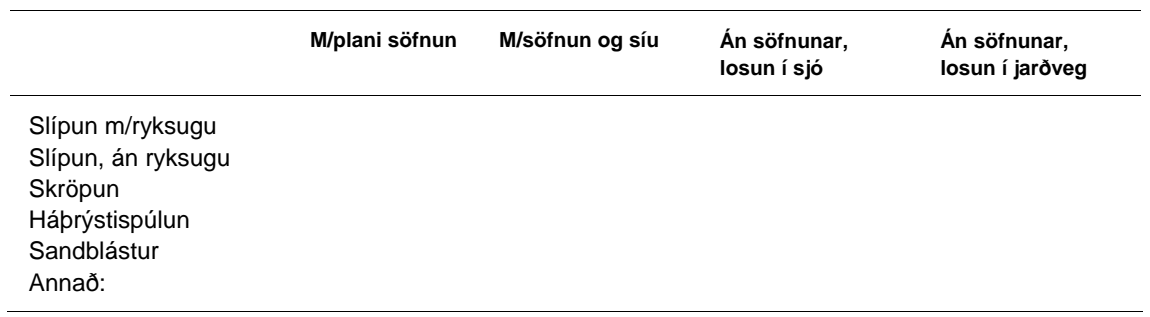




\section{Geymsla}

\begin{tabular}{|c|c|c|c|c|c|}
\hline $\begin{array}{l}\text { Tegund } \\
\text { úrgangs: }\end{array}$ & $\begin{array}{l}\text { Eigin } \\
\text { geymslustöð }\end{array}$ & $\begin{array}{l}\text { Hlutdeild í gámi } \\
\text { sem er merktur } \\
\text { samkvæmt til- } \\
\text { settum reglum }\end{array}$ & $\begin{array}{l}\text { Starfsvenjur } \\
\text { fyrir tæmingu }\end{array}$ & Hlutfall á sjó & $\begin{array}{l}\text { Hlutfall, annað } \\
\text { (lýsa) }\end{array}$ \\
\hline \multicolumn{6}{|l|}{ Sandur } \\
\hline \multicolumn{6}{|l|}{ Úrgangur eftir } \\
\hline \multicolumn{6}{|l|}{ skröpun } \\
\hline \multicolumn{6}{|l|}{ Frárennsli } \\
\hline \multicolumn{6}{|l|}{ Málningarleifar } \\
\hline \multicolumn{6}{|l|}{ Olíuvörur } \\
\hline \multicolumn{6}{|l|}{ Leysingarefni } \\
\hline Annað & & & & & \\
\hline
\end{tabular}

\section{Listi yfir spurningar um viðhorf til reksturs - umhverfisstefna slippstöðvar og nágranna hennar.}

\section{Til slippstöðvar:}

\begin{tabular}{l}
\hline Veistu hvaða reglur gilda um losun á hættulegum eða ópekktum efnum? \\
Veistu hvaða efni er bannað að nota í botnvörn? \\
Veistu hvers vegna er bannað að nota ákveðin efni í botnvörn? \\
Heldur pú að slippurinn losi hættuleg eða ópekkt efni út í náttúruna? \\
Hefur verið gripið til úrræða til að takmarka losun í sambandi við botnviðhald \\
á bátum? \\
Er ráðgert að grípa til úrræða til að takmarka losun við botnviðhald á bátum? \\
Hafa slippstöðinni borist kröfur eða fyrirmæli stjórnvalda vegna losunar?
\end{tabular}

Um nágrenni slippstöðvarinnar:

\begin{tabular}{l}
\hline Spurningarnar varða losun vegna viðhalds/slípunar á bátum. \\
\hline Heldur pú að smábátaslippir losi hættuleg eða ópekkt efni út í náttúruna? \\
Heldur pú að skipti máli fyrir heilsu pína hvort fyrirtækið losar hættuleg eða \\
ópekkt efni út í umhverfið? \\
Heldur pú að opinberar reglur banni losun á hættulegum eða ópekktum \\
efnum út í umhverfið? \\
Heldur pú að slippstöðin beri ábyrgð á hugsanlegri losun vegna viðhalds á \\
bátum? \\
Heldur pú að bátaeigendur beri ábyrgð á hugsanlegri losun vegna viðhalds á \\
bátum?
\end{tabular}




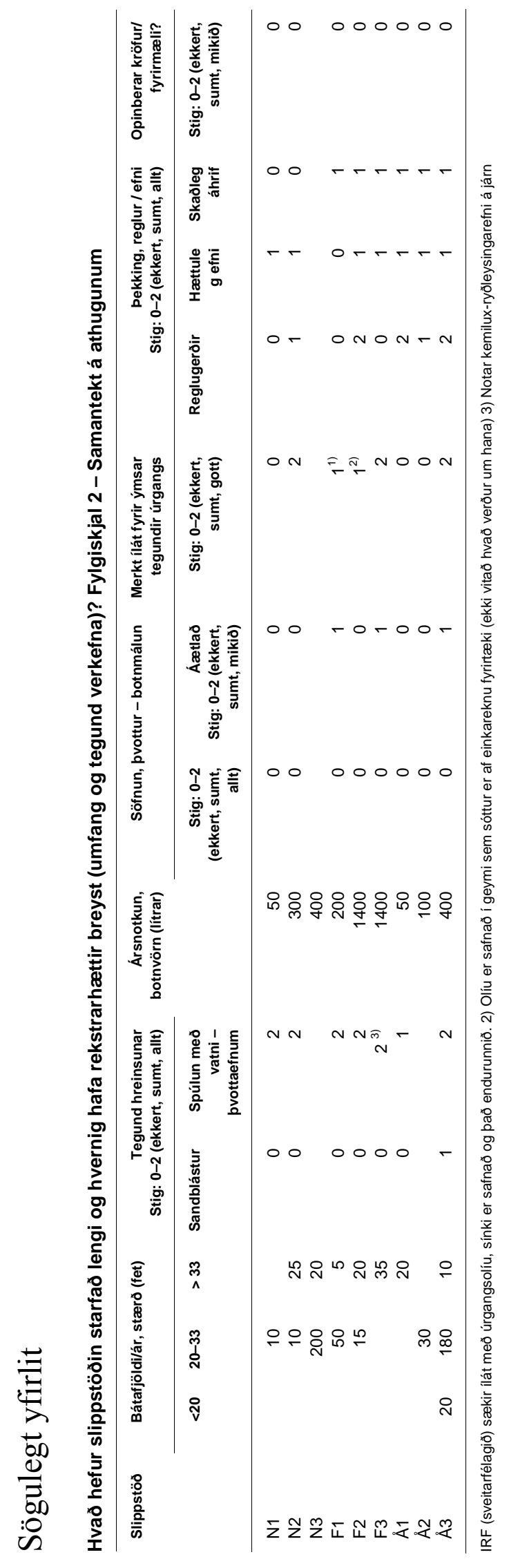

